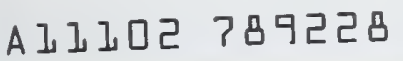

NBS

PUBLICATIONS

NBSIR 88-3690

Report No. 14

\section{Dynamic Mechanical Properties of \\ Two AAR M128 and One ASTM A212-B Steel Tank Car Head Plates}

J.G. Early, C.G. Interrante, S.R. Low, III, and B.A. Fields

U.S. DEPARTMENT OF COMMERCE

National Bureau of Standards

Institute for Materials Science and Engineering

Gaithersburg, MD 20899

February 1988

Issued June 1988

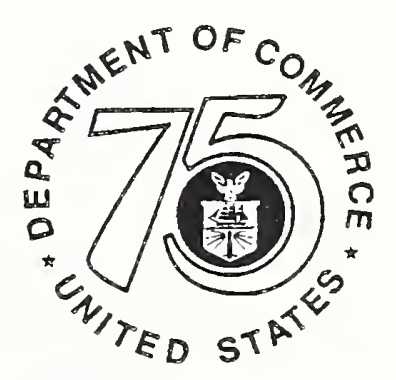

75 Years Silmulating America's Progress
1913-1988

Prepared for:

Federal Railroad Administration

Department of Transportation

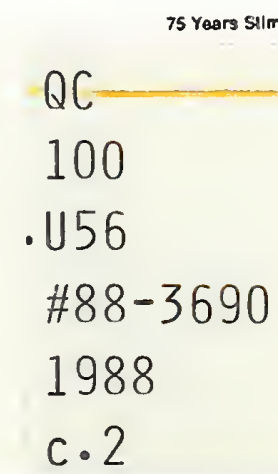



NBSIR 88-3690

Report No. 14

DYNAMIC MECHANICAL PROPERTIES OF TWO

AAR M128 AND ONE ASTM A212-B

STEEL TANK CAR HEAD PLATES

J.G. Early, C.G. Interrante, S.R. Low, III, and B.A. Fields

U.S. DEPARTMENT OF COMMERCE

National Bureau of Standards

Institute for Materials Science and Engineering

Gaithersburg, MD 20899

February 1988

Issued June 1988

Prepared for:

Federal Railroad Administration

Department of Transportation

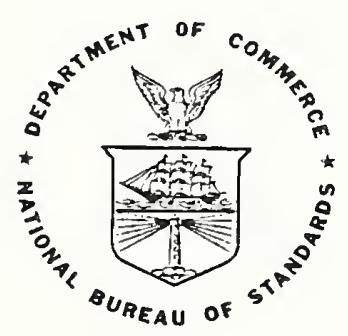

U.S. DEPARTMENT OF COMMERCE, C. William Verity, Secretary

NATIONAL BUREAU OF STANDARDS, Ernest Ambler, Director 

Instrumented precracked Charpy impact testing and dynamic tear testing were carried out on steel plate samples taken from three railroad tank cars. Two of the samples were given as AAR M128, a high strength carbon manganese steel, while the third was reported to be ASTM A212-65, a high strength carbon silicon steel. Values were found for the ranges of transition temperatures and for the energies absorbed, including crack initiation energy, crack propagation energy and total energy.

It should be noted that some of the transition temperatures obtained were within normal tank car service temperature ranges. 
Abstract

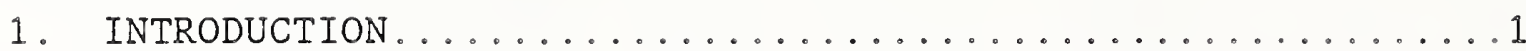

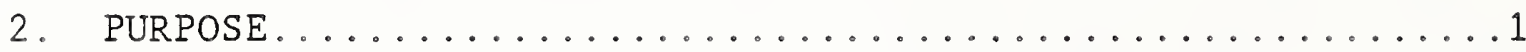

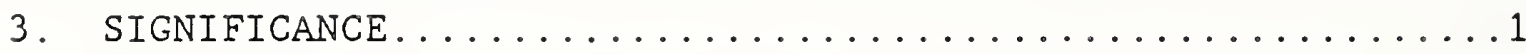

3.1 Instrumented Charpy Impact Test................

3.2 Precracked Charpy Specimen Tests..................

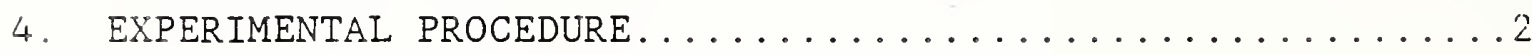

4.1 Instrumented Precracked Charpy Tests..............2

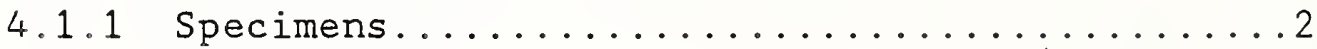

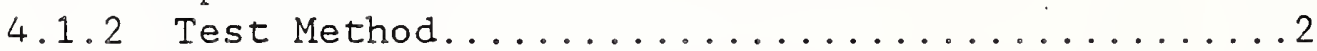

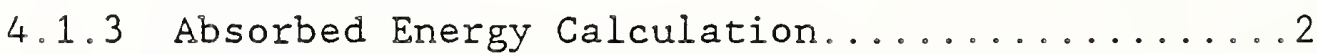

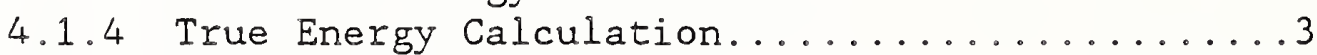

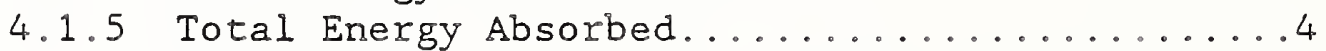

4.1.6 Calculation of. Dynamic Fracture Toughness.....4

4.1.6.1 Linear Elastic Fracture Toughness....4

4.1.6.2 Post General Yield Fracture Toughness.5

4.1.7 Calculation of Dynamic Yield Stress.........5

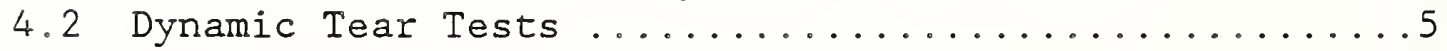

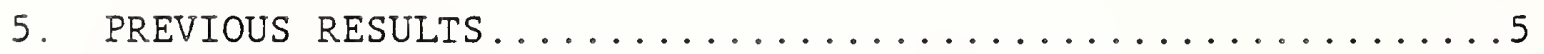

5.1 Compositions and Properties................

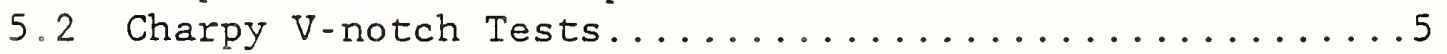

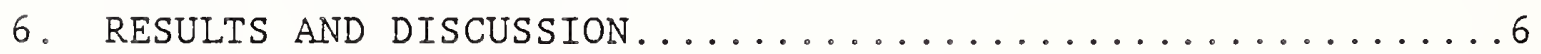

6.1 Instrumented Precracked Charpy Tests..............6

6.1.1 Energy Absorption-Raw Data Values..........6 6

6.1 .2 Transition Temperatures................

6.1 .3 Normalized Energy.....................

6.1.3.1 Total Energy...............

6.1.3.2 Initiation Energy.............

6.1.3.3 Propagation Energy.............

6.1.3.4 Transition Temperatures...........7

6.1 .4 Dynamic Fracture Toughness...............

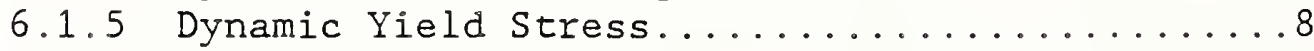

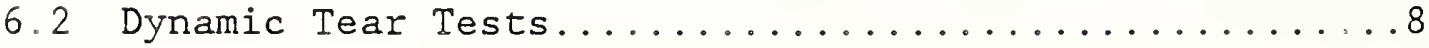

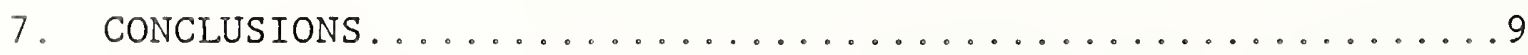

8. ACKNOWLEDGEMENTS ............................. 10

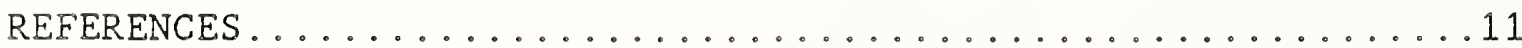




\section{TABLE OF CONTENTS (cont.)}

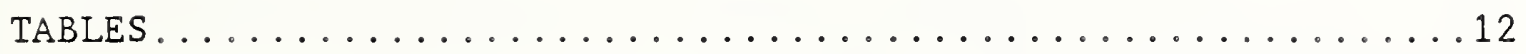

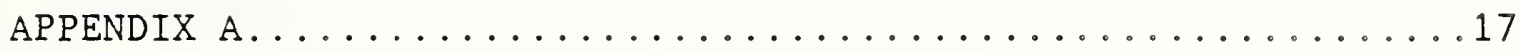

APPENDIX B. . . . . . . . . . . . . . . . . . . . 18

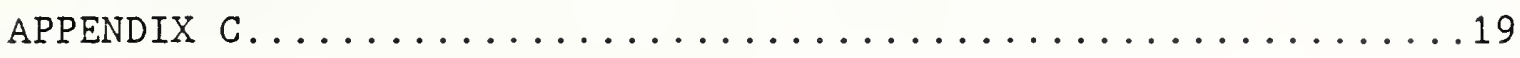

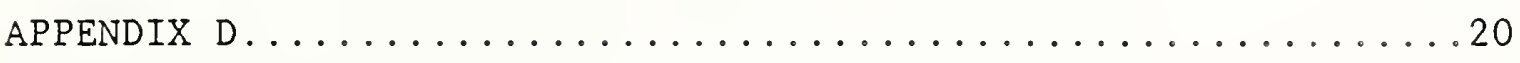

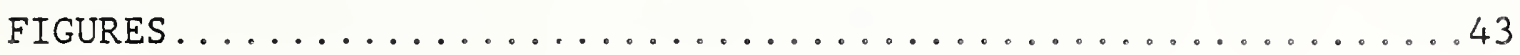




\section{TABLES}

1. Chemical Compositions of Plates $G$ and $U$

2. Chemical Compositions of Plate S

3. Tensile Properties of Plates $G$ and $U$

4. Tensile Properties of Plate S

5. Charpy V-notch Impact and Drop Weight Transition Temperatures for Plates $G, U$, and $S$ 
APPENDICES

A. Limitations Required for a Valid Instrumented Precracked Charpy Test.

B. Compliance Calculations

C. Values of the Function $h(a / W)$ Used to Calculate $\mathrm{K}_{I D}$.

D. Instrumented Precracked Charpy Impact Test Results.

Table D1. Raw Data for LT Orientation, Plate G.

Table D2. Results of Evaluation for LT Orientation, Plate G.

Table D3. Compliance Values for LT Orientation, Plate G.

Table D4. Raw Data for TL Orientation, Plate G.

Table D5. Results of Evaluation for TL Orientation, Plate G.

Table D6. Compliance Values for TL Orientation, Plate G.

Table D7. Raw Data for LT Orientation, Plate U.

Table D8. Results of Evaluation for LT Orientation, Plate U.

Table D9. Compliance Values for LT Orientation, Plate U.

Table D10. Raw Data for TL Orientation, Plate U.

Table D11. Results of Evaluation for TL Orientation, Plate U.

Table D12. Compliance Values for TL Orientation, Plate U.

Table D13. Raw Data for IT Orientation, Plate S.

Table D14. Results of Evaluation for LT Orientation, Plate S.

Dabje D15. Compliance Values for LT Orientation, Plate S.

Sable D16. Raw Data for TL Orientation, Plate S.

Table D17. Results of Evaluation for TL Orientation, Plate S.

Table D18. Compliance Values for TL Orientation, Plate S. 
FIGURES

Figure 1. Idealized Load-Time Record for a Three Point Bend Specimen.

Figure 2. Charpy V-notch-Energy Absorption Results for Plate G.

Figure 3. Charpy V-notch-Energy Absorption Results for Plate U.

Figure 4. Charpy V-notch-Energy Absorption Results for Plate S.

Figure 5. Charpy V-notch-Lateral Expansion Results for Plate G.

Figure 6. Charpy V-notch-Lateral Expansion Results for Plate U.

Figure 7. Chiarpy V-notch-Lateral Expansion Results for Plate S.

Figure 8. Charpy V-notch-Shear Fracture Appearance Results for Plate G.

Figure 9. Charpy V-notch-Shear Fracture Appearance Results for Plate U.

Figure 10. Charpy V-notch-Shear Fracture Appearance Results for Plate S.

Figure 11. Precracked Charpy-Total Energy Absorption Results for Plate G.

Figure 12. Precracked Charpy-Total Energy Absorption Results for Plate U.

Figure 13. Precracked Charpy-Total Energy Absorption Results for Plate S.

Figure 14. Comparison of Total Energy Absorbed for Plates G, U, and S.

Figure 15. Precracked Charpy-Energy Absorbed to Maximum Load for Plate G.

Figure 16. Precracked Charpy-Energy Absorbed to Maximum Load for Plate U.

Figure 17. Precracked Charpy-Energy Absorbed to Maximum Load for Plate S.

Figure 18. Comparison of Energy Absorbed to Maximum Load for Plates G, U, arit $S$.

Figure 19. Comparison of Total Energy and Energy Absorbed to Maximum Load for Plute is.

Figure 20. Comparison of Total Energy and Energy Absorbed to Maximum Load for Plate U.

Figure 21. Comparison of Total Energy and Energy Absorbed to Maximum Load for Plate S.

Figure 22. Comparison of l'otal Energy and Energy Absorbed to Maximum Load for Plates G, U, and $S$.

Eigure 23. Precracked Charpy-Normalized Total Energies for Plate G. 
Figure 24. Precracked Charpy-Normalized Total Energies for Plate U.

Figure 25. Precracked Charpy-Normalized Total Energies for Plate S.

Figure 26. Precracked Charpy-Normalized Initiation Energies for Plate G.

Figure 27. Precracked Charpy-Normalized Initiation Energies for Plate U.

Figure 28. Precracked Charpy-Normalized Initiation Energies for Plate S.

Figure 29. Precracked Charpy-Normalized Propagation Energies for Plate G.

Figure 30. Precracked Charpy-Normalized Propagation Energies for Plate U.

Figure 31. Precracked Charpy-Normalized Propagation Energies for Plate S.

Figure 32. Fracture Toughness Values for Plate G.

Figure 33. Fracture Toughness Values for Plate U.

Figure 34. Fracture Toughness Values for Plate S.

Figure 35. Comparison of $K_{I D}$ Values for Plates $G, U$, and $S$.

Figure 36. Comparison of $K_{J D}$ Values for Plates $G, U$, and $S$.

Figure 37. Dynamic Yield Stresses for Plate G.

Figure 38. Dynamic Yield Stresses for Plate U.

Figure 39. Dynamic Yield Stresses for Plate S.

Figure 40. Dynamic Tear-Energy Absorption Values for Plate G.

Figure 41. Dynamic Tear.Energy Absorption Values for Plate S.

Figure 42. Comparison of Dynamic Tear Results for Plates $G$ and $S$.

Figure 43. Comparison of Resuits for CVN, PCI, and DT Tests for Plate G.

Figure 44. Comparison of Results for CVN and PCI Tests for Plate U.

Figure 45. Comparison of Results for CVN, PCI, and DT Tests for Plate S. 


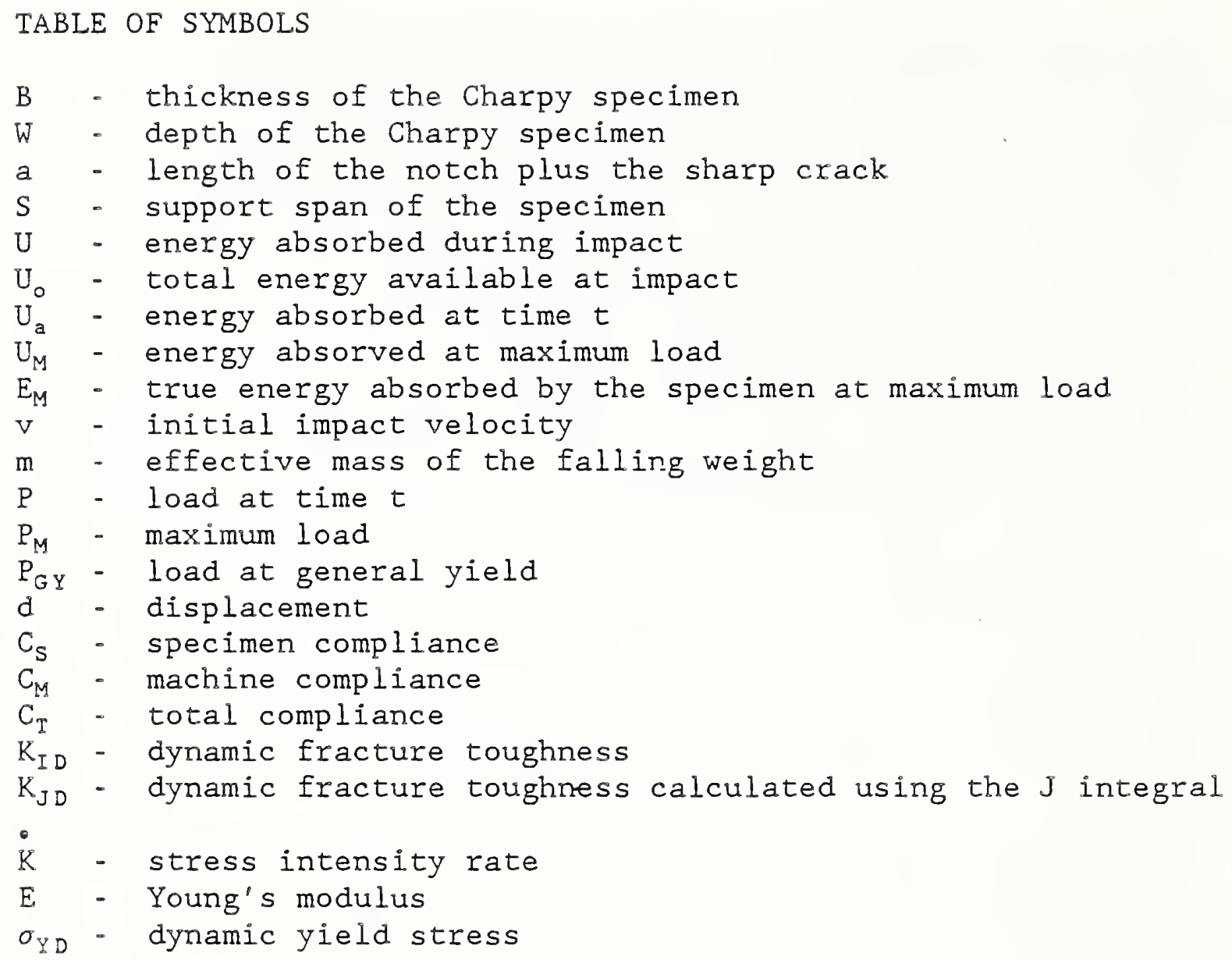




\section{INTRODUCTION}

The National Bureau of Standards was requested by the Federal Railroad Administration, Department of Transportation to conduct metallurgical evaluations of three steel plate samples taken from three railroad tank cars. These tank cars were identified as SOEX 3033, GATX 93412 and UTLX 38498. The details and history of the three tank cars were discussed in previous reports $(1,2)$. For simplicity, the three plate samples will be referred to as $S, G$ and $U$ respectively. Plate $S$ was reported to be ASTM A212-65, a high tensile strength, carbon-silicon steel. Plates $G$ and $U$ were reported to be $A A R$ M128, a high strength carbon manganese steel.

Previous NBS Reports $(1,2)$ have determined that plates $G$ and $U$ met the chemical, tensile strength, and tensile ductility requirements of AAR M128 steel. Plate $S$, however, while satisfying the chemical and tensile elongation requirements of ASTM A212-65 steel, failed to meet those for minimum yield and tensile strengths.

For plates G, U, and $S$ the nil-ductility transition (NDT) temperatures were determined to be $-20^{\circ} \mathrm{F},-40^{\circ} \mathrm{F}$, and $30^{\circ} \mathrm{F}$ respectively. The $15 \mathrm{ft}-1 \mathrm{bs}$ energy absorption temperatures were found to be approximately $-50^{\circ} \mathrm{F},-45^{\circ} \mathrm{F}$, and $67^{\circ} \mathrm{F}$, respectively. The values determined for plate $S$ are of considerable concern as they are well within the normal tank car service temperature range.

\section{PURPOSE}

The purpose of the present evaluation is to study further the impact test behaviors of these plate samples. Both instrumented precracked Charpy tests and dynamic tear tests were carried out over the temperature range of interest.

\section{SIGNIFICANCE}

\subsection{Instrumented Charpy Impact Test}

This test augments the information provided by a standard Charpy impact test. Strain gauges placed on the striking tup are used to sense the load variation with time. A typical load-time plot is shown in Figure 1. Such a plot may be integrated to obtain energies at specified points on the curve, e.g., at yield or maximum load.

\subsection{Precracked Charpy Specimen Tests}

In a precracked Charpy specimen the standard $V$ notch is extended by fatigue cracking to produce a sharp crack representing the most severe condition found in practice. In a standard Charpy test the energy obtained includes both the energy for initiation of the crack and that for its propagation. The energy required to initiate a crack may be considerably greater than that for its propagation. Thus using only the total energy can mask the fact that in a given material the energy required to propagate a crack already present in the material may be quite low. If a precracked Charpy specimen is used the initiation energy will be a much smaller part of the total energy, thus giving 
a more realistic value for propagation energy. This means that a precracked Charpy test more closely simulates the conditions under which an existing crack begins to extend.

Another reason for using precracked specimens is that results for tests where fracture occurs before general yield can be used to calculate a value for dynamic fracture toughness $K_{I D}\left(t_{M}\right)$. This can be correlated with the standard fracture toughness $K_{I C}$. The time value $\left(t_{M}\right)$ (illustrated in Figure 1 ) is the time taken to reach maximum load and references the relative testing rate in units of seconds.

\section{EXPERIMENTAL PROCEDURES}

\subsection{Instrumented Precracked Charpy Tests}

\subsubsection{Specimens}

The nominal dimensions of the specimens were those given in ASTM E23-72 (Notched Bar Impact Testing of Metallic Materials)(Figure 4, Charpy type A). These are 0.394 in $(10 \mathrm{~mm})$ thick by 0.394 in $(10 \mathrm{~mm})$ deep by 2.165 in ( $55 \mathrm{~mm}$ ) long. The machined notch was extended about 0.10 in $(2.5 \mathrm{~mm})$ by fatigue cycling such that the total depth of the notch plus the crack was between 0.177 $(4.5 \mathrm{~mm})$ and 0.217 in $(5.5 \mathrm{~mm})$. The fatigue precracking was carried out following the procedure given in ASTM E399-74.

Two orientations of specimens were used. In one the longitudinal specimen axis was aligned parallel to the rolling direction and the plane of notching was in the transverse direction. In the other the longitudinal axis was in the transverse direction while the notch plane in the rolling direction. These two orientations were given the standard notations of LT and TL.

\subsubsection{Test method}

The specimens were dynamically loaded in three point bending using a standard Charpy machine modified for acquisition of the load-time data. The tests were carried out in accordance with ASTM E23-72.

Additional requirements for acceptable frequency response, inertial oscillation dampening, velocity reduction and electronic curve fitting, as discussed by Server ${ }^{(3)}$ are summarized in Appendix A.

\subsubsection{Absorbed Energy Calculation}

The energy absorbed ( $U$ ) at any time ( $t$ ) during the impact event can be computed from the instrumented tup load-time record as follows ( 3 )

$$
U=U_{a}\left(1-\frac{U_{a}}{4 U_{0}}\right)
$$

where $U_{0}$ is the total available energy at impact, $1 / 2 \mathrm{mV}_{0}{ }^{2}$, and $U_{a}$ is determined at time $t$ as follows: 


$$
U_{a}=V_{0} \int_{0}^{t} P d t
$$

where $V_{0}$ is the initial impact velocity, $P$ is the load, and $m$ is the effective mass of the falling weight. The energy absorbed at maximum load, $U_{M}$, can be determined from the above expression when $t=t_{M}$ (see Figure 1 ).

When comparing energies absorbed in standard Charpy $V$-notch specimens and precracked specimens it should be noted that the ligament area, $B(W-a)$ (where $B$ is the specimen thickness, $W$ is the depth, and $a$ is the length of the notch plus the crack), will be smaller in the latter case because of the extension of the notch by fatigue cracking. Thus, it is not accurate to directly compare energies for the two types of specimens. A solution is to normalize the energy values by dividing by the fracture ligament area.

\subsubsection{True Energy Calculations}

The value of the energy calculated from the area under the load-time curve (equation 1) includes contributions due to the deflections of both the specimen and that of the testing machine. A calculation of true energy absorbed, therefore, needs to include a correction for the machine compliance.

For tests when fracture is linear elastic, the normalized value of $E_{M}$ can be calculated directly from the area under the load-displacement curve:

$$
E_{M}=\frac{P_{M} d}{2 B(W-a)}
$$

where $d$ is displacement. Since the specimen compliance $C_{S}$, is defined as

$$
C_{S}=\mathrm{d} / \mathrm{P}
$$

it follows that

$$
E_{M}=\frac{P_{M}^{2} C_{S}}{2 B(W-a)}
$$

For a caiculation of $C_{S}$ see Appendix $B$.

When general yield occurs before fracture a correction must be made to equation 1. If the total energy under the load-time curve is $U_{M}$, then the true energy absorbed at maximum load, $E_{M}$, is given by

$$
E_{M}=U_{M}-\frac{P_{M}^{2} C_{M}}{2 B(W-a)}
$$

where $C_{M}$ is the machine compliance and can be calculated from

$$
C_{M}=C_{T}-C_{S}
$$


where $C_{T}$ is the total system compliance. Therefore

$$
E_{M}=U_{M}-\frac{P_{M}^{2}\left(C_{T}-C_{S}\right)}{2 B(W-a)}
$$

For a calculation of $C_{T}$ see Appendix B.

The value of $E_{M}$ obtained is a measure of the initiation energy, i.e. the energy required to initiate cracking.

\subsubsection{Total Energy Absorbed}

The values of total energy absorbed were obtained from the dial energy recorded. As was described in section 4.1.3. a direct comparison of energies absorbed in different specimens is achieved by normalizing the energy values by the fracture ligament area, i.e. by $B(W-a)$.

\subsubsection{Calculations of Dynamic Fracture Toughness}

\subsubsection{Linear Elastic Fracture Toughness}

The dynamic fracture toughness, $K_{I D}$ can be calculated from the measured value of maximum load, $P_{M}$, and the initial specimen dimensions, in the manner specified by ASTM Method E399-74. The general specimen size requirements of this method appear to be too conservative for dynamic testing $(4)(5)$. It is therefore suggested by Server ${ }^{3)}$ that as long as general yielding has not occurred, a linear elastic value of fracture toughness can be calculated.

The relationship for $K_{I D}$ in units of psidin $(M P a / m)$, where $B=W$ and $S=4 W$ is

$$
K_{I D}=P_{M} h(a / W)
$$

where $B$ is specimen thickness, $S$ is the support span, $W$ is the specimen depth, $a$ is the crack length and the function $h(a / W)$ is given in Appendix $C$.

The fracture toughness values can be reported as $K_{I D}\left(t_{M}\right)$ where the time value, $t_{M}$, raferences the relative testing rate in units of seconds. The stress intersity rate, $\dot{\mathrm{k}}$, car be calculated as

$$
\dot{K}=\mathrm{K}_{I D} / t_{M}
$$

For impact loading a minimum value of $\dot{K}$ obtained is of the order of $0.9 \times 10^{5} \mathrm{ksi} \cdot \mathrm{in}^{1 / 2} / \mathrm{s}\left(1 \times 10^{5} \mathrm{MPa} \cdot \mathrm{m}^{2 / 2} / \mathrm{s}\right)$. 


\subsubsection{Post General Yield Fracture Toughness}

When general yielding occurs a valid $K_{I D}$ cannot be determined from a linear elastic analysis. An energy-based value of the $\mathrm{J}$ integral can be used to obtain a measure of fracture toughness. (3) When the initiation load can be determined and $a / W \geq 0.5^{(6)}(7)$

$$
J_{I D}=2 E_{M} / B(W-a)
$$

A dynamic value of the toughness $K_{J D} c a n$ be given as

$$
K_{J D}=\left(E J_{I D}\right)^{1 / 2}
$$

where $\mathrm{E}$ is Young's Modulus. Therefore

$$
K_{J D}=\left(2 E E_{M} / B(W-a)\right)^{1 / 2}
$$

\subsubsection{Dynamic Yield Stress}

The dynamic yield stress, $\sigma_{Y D},^{\cdot}$ can be calcuated from an equation of the form ${ }^{(4)}$

$$
\sigma_{Y D}=A P_{G Y} \frac{W}{B(W-a)^{2}}
$$

where $A$ is a constant. The upper and lower bounds for the value of $A$ are given by $\operatorname{Knott}^{(8)}$ to be about 2.5 and 4. For the present work, following Server ${ }^{(9,}$ 10), a value of 3.3 was used.

\subsection{Dynamic Tear Tests}

Testing procedure followed that given in ASTM Method E604-77. The specimen dimensions were: length 7.125 in $(181 \mathrm{~mm})$, width $1.6 \mathrm{in}(40.6 \mathrm{~mm})$ and thickness 0.625 in $(15.9 \mathrm{~mm})$.

\section{PREVIOUS RESULTS}

\subsection{Compositiors and Properties}

The chemical compusitions, as determined by check chemical analyses of the plate samples, are given in Tables 1 and 2. Results of these analyses along with those for macroscopic observations, metallographic analyses, hardness measurements, bend behavior and inclusion contents were given and discussed in the two previous reports $(1 ; 2)$. Also given previously, and reproduced here, were the tensile properties (Tables 3 and 4 ) for all three plates.

\subsection{Charpy V-notch Tests}

Figures 2 - 10 are given for comparison with the present work. They show the results of the previously conducted Charpy $V$-notch (CVN) impact tests for both longitudinal (LT) and transverse (TL) specimens. These include results for 
energy absorption, lateral expansion, shear fracture appearance and nilductility temperature. Table 5 shows the transition temperatures for four commonly reported fracture criteria: $15 \mathrm{ft}$-lbf energy absorption, $15 \mathrm{mil}$ lateral expansion, $50 \%$ shear fracture appearance and nil ductility. These results have been discussed in the previous reports. Of note are the transition temperatures for plate $S$ which all fall within the normal tank car service temperature range, e.g., a transition temperature of $67^{\circ} \mathrm{F}\left(19^{\circ} \mathrm{C}\right)$ for the $15 \mathrm{ft}$-lbs energy absorption. This is cause for concern since it indicates that for temperatures lower than $67^{\circ} \mathrm{F}\left(19^{\circ} \mathrm{C}\right)$ a crack that initiates may propagate in a brittle fashion, possibly leading to fracture.

\section{RESULTS AND DISCUSSION}

\subsection{Instrumented Precracker Charpy Tests}

The raw and calculated data for all the precracked tests are given in Appendix D, Tables D1 through D18. The tests from which these results were taken all satisfied the acceptance criteria as discussed in section 4.1.2. and Appendix A.

\subsubsection{Energy Absorption - Raw Data Values}

Figure 11-13 show the total energy absorbed, $E_{\mathrm{T}}$, as measured by the dial gauge, for each of the plates, G, U, and S. Results are shown for both LT and TL specimens. Figure 14 compares these results. Figures 15-17 show the energy absorbed up to the point of maximum load, $E_{M}$. These values were calculated as described in section 4.1.3. Figure 18 compares the results presented in Figures 15-17. Figures 19-21 compare $E_{M}$ and $E_{T}$ for $T L$ specimens taken from each plate. Figure 22 provides a comparison of all data in Figures 19-21.

It should be noted that Figures 11-22 show unnormalized energy absorption data. In order to compare these values with those obtained for standard CVN specimens they may be multiplied by $\left(W-a_{1}\right) /\left(W-a_{2}\right)$ where $a_{1}$ is the standard notch length and $a_{2}$ is the length of the notch plus the fatigue crack. This corrects for the different ligament areas as discussed in section 4.1.3. Using $W=0.394$ in $(10 \mathrm{~mm}), a_{1}=0.10$ in $(2.5 \mathrm{~mm})$ and assuming that the fatigue crack is of length 0.10 in $(2.5 \mathrm{~mm})$, this factor becomes 1.5 . Subsequent energy values quoted have been corrected in this fashion.

The value of $E_{M}$ can be considered as a measure of the energy required to initiate an extension to an existing sharp crack. It can be seen in Figure 22 that these energies, when corrected as described, are very small, of the order of 5-6 ft-lbf (3.7 - $4.4 \mathrm{~J})$ at the upper shelf and of less than $1 \mathrm{ft}-1 \mathrm{bf}(.7 \mathrm{~J})$ at the lower shelf. Thus, as stated earlier, very little energy is needed to initiate an extention of a sharp crack.

The values of $E_{T}$ are within a range of 22 to $29 \mathrm{ft}-\mathrm{lbf}(16-21 \mathrm{~J})$ for the upper shelf. These should be compared with the energies absorbed in the standard CVN TL specimens which fall in a range of about 37 - $47 \mathrm{ft}-\mathrm{lbf}$ (27 $35 \mathrm{~J}$ ) on the upper shelf (Figures $2-4$ ). It can be seen, therefore, that the energies required to initiate and propagate an existing sharp crack are 
considerably less that that needed to fracture a standard notched specimen.

\subsubsection{Transition Temperatures}

The transition region is the range of temperatures over which a transition from brittle to ductile fracture is observed. At lower temperatures in the range the fracture is predominately of a brittle or cleavage mode, while at higher temperatures fracture is dominated by a ductile or fibrous mode. For plates $G$ and $U$ the transition in precracked specimens occurs over a temperature range of approximately -70 to $-10 \mathrm{~F}(-56$ to $-23 \mathrm{C})$. For plate $\mathrm{S}$ the range is about 30 to $130 \mathrm{~F}$ (-1 to 54C). As noted previously for the CVN specimens the latter temperatures are within the range for normal tank car service. This indicates that brittle crack propagation may occur at the lower temperatures of this range.

\subsubsection{Normalized Energy}

\subsubsection{Total Energy Absorbed}

Figures 23-25 show the values of the $E_{T}$, the total energy absorbed for plates $G, U$, and $S$ respectively. These values were obtained from the dial energy normalized by the ligament area as discussed in section 4.1.3.

\subsubsection{Initiation Energy}

Figures 26-28 show the initiation energies, $E_{M}$, for each of the plates. These values were obtained from the energy absorbed up to maximum load, $U_{M}$, corrected for the deflection of the testing machine as described in section 4.1.4. In this case 'initiation' means the point of extension of the already existing fatigue crack. It can be seen that on the lower shelf these values are very low - of the order of $57 \mathrm{in}-\mathrm{lbf} / \mathrm{in}^{2}\left(10 \mathrm{~kJ} / \mathrm{m}^{2}\right)$ or less - for each of the plates.

\subsubsection{Propagation Energy}

The energy required for propagation of the crack was calculated as the difference between total energy absorbed and initiation energy. The results are plotted in Figures 29-31. For plates $G$ and $S$ the points are somewhat scattered making it hard to evaluate lower or upper shelf values. However it can be seen that these energies are considerably larger than those for initiation.

\subsubsection{Transition Temperatures}

The transition temperature ranges for total energies absorbed can be seen in Figures 23 - 25. For plate TL specimens of plate $G$ this range is about -40 to $20 \mathrm{~F}$ ( -40 to $-29 \mathrm{C}$ ), of plate $U$ about -50 to $\mathrm{OF}(-46$ to $-18 \mathrm{C}$ ) and of plate $\mathrm{S}$ up to about $125 \mathrm{~F}$ (52C). These compare with values found for the $15 \mathrm{ft}-1 \mathrm{bf}$ energy absorption for TL specimens of $-46 \mathrm{~F}(-43 \mathrm{C}),-41 \mathrm{~F}(-42 \mathrm{C})$ and $67 \mathrm{~F}(19 \mathrm{C})$ for plates G, U, and $S$ respectively. 


\subsubsection{Dynamic Fracture Toughness}

Figures 32-34 show the dynamic fracture toughness versus temperature for each of the plates, $G, U$, and $S$. Figure 35 shows a comparison for valid $K_{I C}$ results from the three plates. Figure 36 includes all the $\mathrm{K}_{\mathrm{JD}}$ values for $\mathrm{TL}$ orientation specimens of each plate.

For plate G (Figure 32) valid $K_{I D}$ values are of the order of $50 \mathrm{ksi} /$ in ( 55 $\mathrm{MPa} / \mathrm{m})$. The highest temperature at which a valid result was obtained was $O F$ $(-18 \mathrm{C})$. The transition temperature range was about -13 to $14 \mathrm{~F}$ ( -25 to $-10 \mathrm{C})$. For the upper shelf there was a considerable difference in the toughness, $\mathrm{K}_{J D}$, between the LT and TL orientations. The former had a toughness of the order of $200 \mathrm{ksi} /$ in $(220 \mathrm{MPa} / \mathrm{m})$, while the latter was about $150 \mathrm{ksi} /$ in $(165 \mathrm{MPa} / \mathrm{m})$. This difference between the two orientations was also found in the energy absorption results, see Figures 11 and 15 . This is a consequence of a large difference in the times taken to reach maximum load, $t_{M}$, for specimens of the two orientations. For the TL specimens $t_{M}$ is 3 to 5 times greater than for the LT specimens, as can be seen in Table D1.

For plate U (Figure 33) the results are not dependent on orientation. The lower shelf fracture toughness is about $50 \mathrm{ksi} / \mathrm{m}$ ( $55 \mathrm{MPa} / \mathrm{m}$ ), while that of the upper shelf is of the order of $180 \mathrm{ksi} /$ in $(200 \mathrm{MPa} / \mathrm{m})$. The transition temperature is around $-15 \mathrm{~F}(-26 \mathrm{C})$. The highest temperature at which a valid $K_{I C}$ was recorded was $-30 \mathrm{~F}(-34 \mathrm{C})$.

For Plate S (Figure 34) the lower and upper shelves also have values of the order of 40 and $180 \mathrm{ksi} / \mathrm{in}(44$ and $200 \mathrm{MPa} / \mathrm{m}$ ) respectively. The most significant difference between Plate $S$ and Plates $G$ and $U$ is that the transition temperature of the former is about $122 \mathrm{~F}$ (50C), compared to a value of about $-13 \mathrm{~F}(-25 \mathrm{C})$ for the latter two plates. A valid $\mathrm{K}_{\text {ID }}$ of $39 \mathrm{ksi} / \mathrm{in}$ ( 43 $\mathrm{MPa} / \mathrm{m}$ ) was obtained at a temperature of $125 \mathrm{~F}$ (52C). This indicates that at temperatures up to around $125 \mathrm{~F}$ (52C) an existing sharp crack subjected to impact loading could propagate in a brittle fashion, possibly causing failure.

\subsubsection{Dynamic Yield Stress}

Figures 37-39 show the results for dynamic yield stresses for plates $G$, $U$, and $S$, respectively. For plate $G$, there is a decrease in $\sigma_{Y D}$ with increasing temperature as would be expected. For plates $U$ and $S$ the results are so scattered that no trend is visible. At least part of this scatter is attributable to the variation in the rate of testing as shown by the values of $t_{M}$ given in the raw data tables in Appendix $D$.

\subsection{Dynamic Tear Tests}

Figures 40 and 41 show the energy absorbed in the dynamic tear tests for plates $G$ and $S$. No tests were carried out for plate U. Figure 42 compares the data from Figures 40 and 41 . The results for plate $G$ are somewhat scattered giving a wide range for the transition temperature of about 0 to $80 \mathrm{~F}$ (-18 to 27C) which overlaps the range of about 60-80F (16 to 27C) for plate S. It should be noted that for both plates these ranges include normal service temperatures for tank cars. 
Figures 43 and 45 show a comparison of energy absorption results for Charpy Vnotch (CVN), precracked Charpy (PCI) and dynamic tear (DT) transverse specimens for plates $G$ and $S$. The energy values are normalized so that the upper shelf energies are all equal to $100 \mathrm{ft}-\mathrm{lbf}$. Figure 44 shows the same results for plate $U$ with the exception of dynamic tear results which were not obtained for this plate. The purpose of these figures is to show the variation in transition temperature ranges for the three different tests.

For plate $G$ the DT tests show a large upward shift of the transition temperature compared to those for CVN and PCI tests. Since the specimens for the DT test are larger than the Charpy specimens it is possible that the greater constraint in the former leads to a higher transition temperature range. As noted previously, this higher range includes normal operating temperatures. For plate $U$ the $C V N$ and PCI results show rang's similar to each other within experimental error. For plate $S$ transition temperature ranges for all three tests are within normal service temperatures.

\section{CONCLUSIONS}

1. The results of the precracked Charpy tests show that:

a. The lower shelf for the normalized total energy absorbed is of the order of $600 \mathrm{in}-\mathrm{lbf} / \mathrm{in}^{2}\left(105 \mathrm{~kJ} / \mathrm{m}^{2}\right)$ for plates $G$ and $U$ and about 1000 in$\mathrm{lbf} / \mathrm{in}^{2}\left(175 \mathrm{KJ} / \mathrm{m}^{2}\right)$ for plate $\mathrm{S}$.

b. The upper shelf for the normalized total absorbed energy is about 2300 in-lbf/in ${ }^{2}\left(403 \mathrm{~kJ} / \mathrm{m}^{2}\right)$ for $\mathrm{TL}$ specimens of $\mathrm{G}$, and $2500 \mathrm{in}-\mathrm{lbf} / \mathrm{in}^{2}$ (438 $\mathrm{KJ} / \mathrm{m}^{2}$ ) for plate $\mathrm{U}$ and for $\mathrm{TL}$ specimens of plate $\mathrm{S}$.

c. The transition temperature range for plate $G$ is approximately -40 to $-20 \mathrm{~F}$ ( -40 to $-29 \mathrm{C}$ ), for plate $U$ about -50 to OF ( -46 to $-18 \mathrm{C}$ ), and for plate $S$ of up to $125 \mathrm{~F}(52 \mathrm{C})$. For a plate containing a sharp crack, brittle propagation may occur at and below the lower end of this range. For plate $S$ this is of concern since these temperatures include those found under normal service conditions.

d. When a sharp crack is present in a plate the energy to initiate further cracking is of the order of $57 \mathrm{in}-1 \mathrm{bf} / \mathrm{in}^{2}\left(10 \mathrm{KJ} / \mathrm{m}^{2}\right)$ or less for all three plates.

e. Valid fracture toughness tests give $K_{I D}$ values of about $46 \mathrm{ksi} /$ in ( 50 $\mathrm{MPa} \sqrt{\mathrm{m}}$ ) for all three plates.

f. Upper shelf values of post general yield fracture toughness, $\mathrm{K}_{\mathrm{J} D}$, are approximately $137 \mathrm{ksi} / \mathrm{in}(150 \mathrm{MPa} / \mathrm{m})$ for all three plates.

g. The transition temperatures for fracture toughness values are of the order of $-13 \mathrm{~F}(-25 \mathrm{C})$ for plates $G$ and $U$, and $122 \mathrm{~F}$ (50C) for plate $\mathrm{S}$.

h. The dynamic yield stresses calculated show a wide scatter believed to be largely caused by differences in the rate of testing. 
2. The results of the dynamic tear tests show that:

a. For plate $G$ the transition temperature range is considerably higher than that for the precracked Charpy tests, i.e. about 0 to $120 \mathrm{~F}$ (-18 to 49C) compared to about -40 to $-20 \mathrm{~F}$ ( -40 to $-29 \mathrm{C})$. Since the specimens for the dynamic tear tests are larger than the Charpy specimens it is possible that the greater constraint in the former leads to a higher transition temperature range. It should be noted that this higher range includes normal service temperatures.

b. For plate $S$ the transition temperature range for the dynamic tear test is about 60 to $130 \mathrm{~F}$ ( 16 to 54C) compared to a precracked Charpy range of up to $125 \mathrm{~F}$ (52C). Both ranges include normal service temperatures.

\section{ACKNOWLEDGEMENTS}

The authors wish to express thanks to Mr. D.E. Harne for his contribution to the mechanical testing involved in this project, and to Mrs. J. Vaughan for typing the manuscript and to the Federal Railroad Administration for support and valuable comments and advice. 


\section{REFERENCES}

1. Early, J.G., "A Metallurgical Analysis of an ASTM A212-B Steel Tank Car Head Plate," Report No. NBSIR-78-1582, National Bureau of Standards, Sept. 1978.

2. Early, J.G., and Interrante, C.G., "A Metallurgical Evaluation of Two AAR M128 Steel tank Car Head Plates Used in Switchyard Imact Tests," Report No. NBSIR-80-2039, National Bureau of Standards, May 1980.

3. Server, W.L., "Impact Three-Point Bend Testing for Notched and Precracked Specimens," Journal of Testing and Evaluation, JTEVA, Vol. 6, No. 1, Jan. 1978, pp $29-34$.

4. Server, W.L., Wullaert, R.A., and Sheckherd, J.W., "Verification of the EPRI Dynamic Fracture Toughness Testing Procedures, "Report TR75-42, Effects Technology, Inc., Santa Barbara, California, October 1975.

5. Wullaert, R.A., Oldfield, W., and Server, W.L., "Fracture Toughness Data for Ferritic Nuclear Pressure Vessel Materials: Task A, "Final Report to the Electric Power Research Institute on Research Project PR232-1, EPRI Report NP-121, Palo Alto, California, April 1976.

6. Rice, J.R., "Mathematical Analyses in the Mechanics of Fracture," in Fracture, An Advance Treatise, Vol. 2, H. Liebowitz, Ed., Academic Press, New York 1968.

7. Sumpter, J.D.G. and Turner, C.E., "Method for Laboratory Determination of $\mathrm{J}_{c}$," in Cracks and Fracture, STP 601, American Society for Testing and Materials, Philadelphia, 1976, pp. 3-18.

8. Knott, J.F., "Fundamentals of Fracture Mechanics," Butterworths, 1973, pp. $37-38$.

9. Server, W.L. and Wullaert, R.A., "Dynamic Three-Point Bend Analysis for Notched and Precracked Samples," Fracture Control Corporation, FCC 76-8, Aug. 1976.

10. Server, W.L., "Dynamic Fracture Toughness Determined from Instrunented Precracked Charpy Ttists," UCLA-ENG-7267, Aug. 1972. 
Table 1. Chemical Compositions of Plates $G$ and $U$.

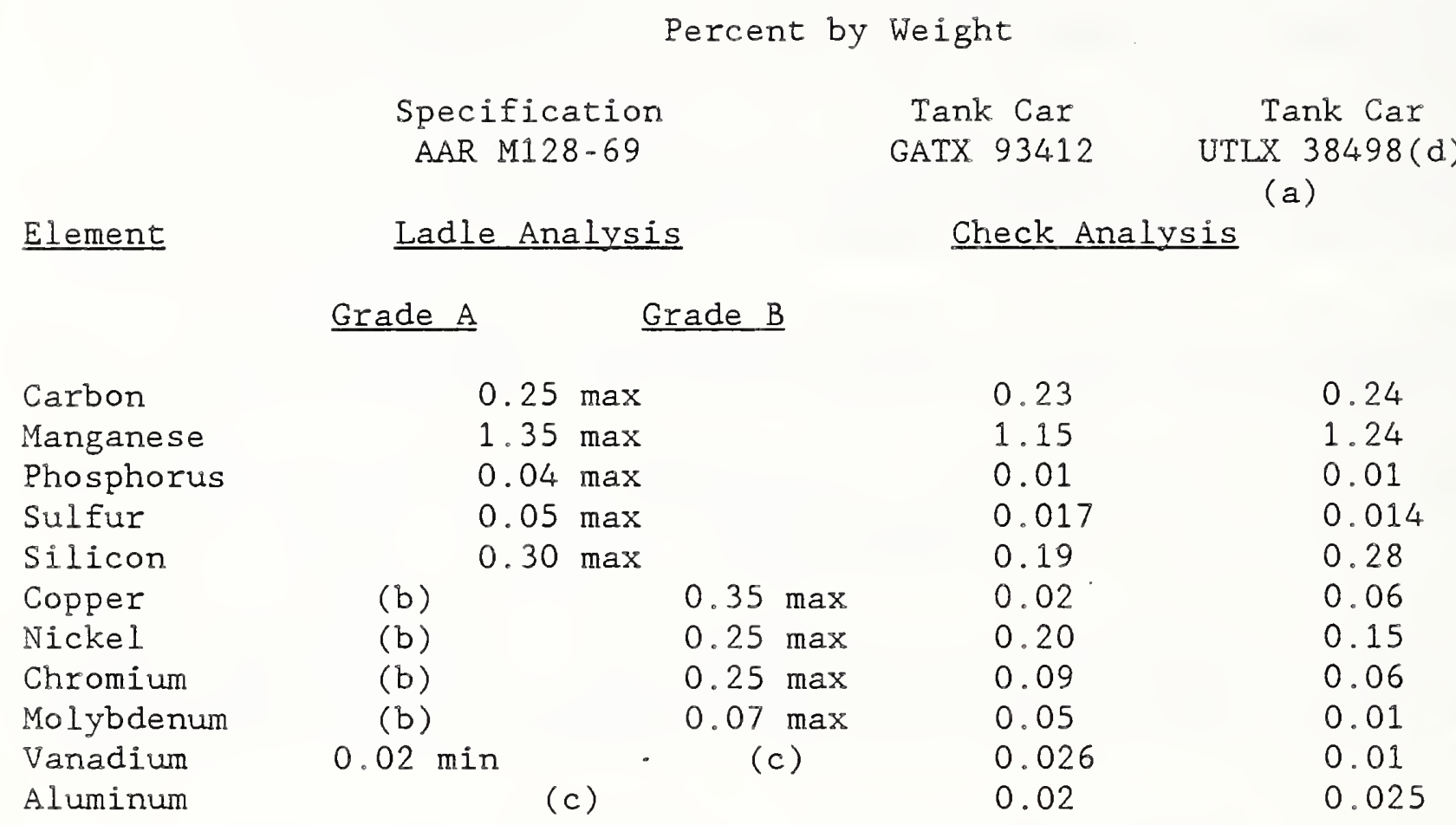

(a) Carbon was determined by combustion-conductometric analysis; all other elements were determined by emission spectroscopy.

(b) Element not specified.

(c) Element not specified, fine grain practice is required.

(d) Producers Report: UTLX 38498 plate sample is reported to be Kawasaki heat number 91-7850, AAR M128-B, with the ladle analysis of 0.25 carbon, 1.30 manganese, 0.0015 phosphorus, 0.0019 sulfur, 0.29 silicon, 0.08 copper, 0.15 nickel, 0.05 chromium, and 0.0015 molybdenum; all weight percent. 
Table 2. Chemical Compositions of Plate S

Percent by Weight

Specification ASTM A212-65-B

Element Ladle Analysis

Check Analysis (a)

Carbon

Manganese

Phosphorus

Sulfur

Silicon

Copper

Nickel

Chromium

Molybdenum

$0.31 \max$

$0.90 \max$

$0.04 \max$

$0.05 \mathrm{max}$

$0.13 / 0.33^{(b)}$

(c)

(c)

0.24

0.73

$<0.005$

0.026

0.26

$<0.05$

$<0.05$

(c)

0.07

(c)

$<0.05$

(d)

$<0.01$

Vanadium

(d)

$<0.01$

(a) Carbon was determined by combusion-conductometric analysis; all other elements were determined by emission spectroscopy.

(b) Check analysis

(c) Element not specified

(d) Element not specified, either fine-or coarse-grain practice allowed. 


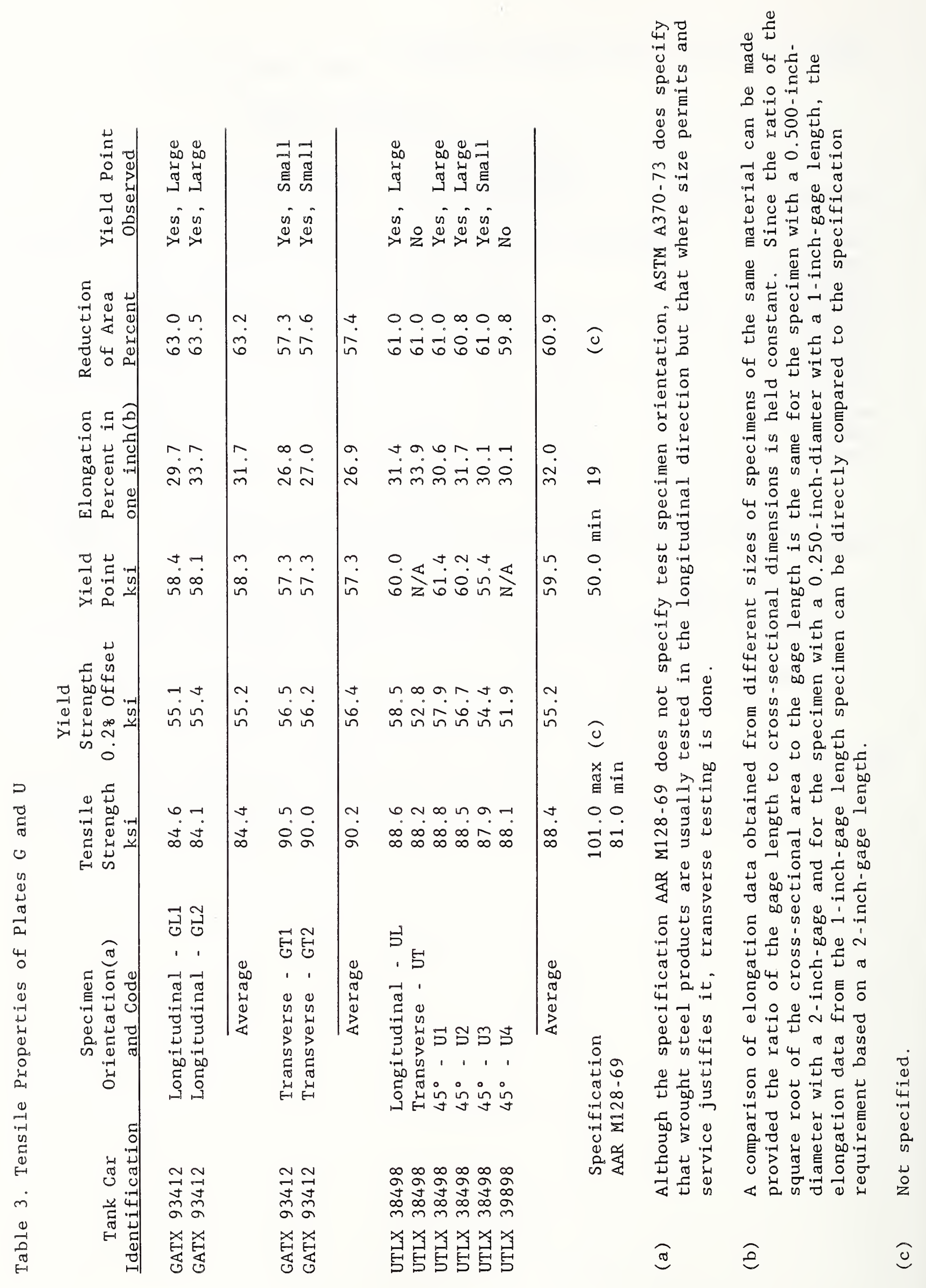


Table 4. Tensile Properties of Plate S

\begin{tabular}{|c|c|c|c|c|c|}
\hline $\begin{array}{c}\text { Specimen } \\
\text { Orientation(a) } \\
\text { and Code } \\
\end{array}$ & $\begin{array}{l}\text { Tensile } \\
\text { Strength } \\
\text { ksi }\end{array}$ & $\begin{array}{c}\text { Yield Strength } \\
0.2 \% \text { Offset } \\
\mathrm{ksi}\end{array}$ & $\begin{array}{l}\text { Yield } \\
\text { Point } \\
\text { ksi }\end{array}$ & $\begin{array}{l}\text { Elongation } \\
\text { Percent in } \\
\text { one inch(b) }\end{array}$ & $\begin{array}{l}\text { Reduction } \\
\text { of Area } \\
\text { Percent }\end{array}$ \\
\hline $\begin{array}{l}\text { Longitudinal - SL1 } \\
\text { Longitudinal - SL2 }\end{array}$ & $\begin{array}{l}68.1 \\
67.7\end{array}$ & $\begin{array}{l}33.0 \\
33.0\end{array}$ & $\begin{array}{l}35.0 \\
33.4\end{array}$ & $\begin{array}{l}37.7 \\
37.1\end{array}$ & $\begin{array}{l}61.3 \\
61.5\end{array}$ \\
\hline Average & 67.9 & 33.0 & 34.2 & 37.4 & 61.4 \\
\hline $\begin{array}{l}\text { Transverse - ST1 } \\
\text { Transverse - ST2 }\end{array}$ & $\begin{array}{l}67.7 \\
67.6\end{array}$ & $\begin{array}{l}32.2 \\
32.2\end{array}$ & $\begin{array}{l}34.3 \\
N / A\end{array}$ & $\begin{array}{l}35.5 \\
36.0\end{array}$ & $\begin{array}{l}56.4 \\
58.0\end{array}$ \\
\hline Average & 67.6 & 32.2 & 34.3 & 35.8 & 57.2 \\
\hline $\begin{array}{l}\text { Specification } \\
\text { ASTM A212-B-65 }\end{array}$ & $\begin{array}{ll}85.0 & \max \\
70.0 & \min \end{array}$ & (c) & 38.0 & $\min$ & (c) \\
\hline
\end{tabular}

(a) Although the specification ASTM A212-65 does not specify test specimen orientation, ASTM A370-73 does specify that wrought steel products are usually tested in the longitudinal direction but that where size permits and service justifies it, transverse testing is done.

(b) A comparison of elongation data obtained from different sizes of specimens of the same mateial can be made prodived the ratio of the gage length to cross-sectional dimensions is held constant. Since the ratio of the square root of the cross-sectional area to the gage length is the same for the specimen with a 0.500 -inch-diameter with a 2 -inchgage and for the specimen with a 0.250 -inch-diameter with a 1 -inch-gage length, the elongation data from the 1 -inch-gage length specimen can be directly compared to the specification requirement based on a 2 -inchgage length.

(c) Not specified. 
Table 5. Charpy V-notch Impact and Drop Weight Transition Temperatures for Plates $G, U$, and $S$.

\begin{tabular}{|c|c|c|c|c|c|}
\hline Plate & $\begin{array}{c}\text { Specimen } \\
\text { Orientation }\end{array}$ & $\begin{array}{c}15 \mathrm{ft}-\mathrm{lbf} \\
\text { Energy } \\
\text { Absorption }\end{array}$ & $\begin{array}{c}\text { ansition } \mathrm{Te} \\
15 \mathrm{mil} \\
\text { Laterial } \\
\text { Expansion }\end{array}$ & $\begin{array}{l}\text { Eure, F/C } \\
50 \% \\
\text { Shear } \\
\text { Fracture }\end{array}$ & $\begin{array}{c}\text { Nil } \\
\text { Ductility } \\
\text { Temp. } \\
\end{array}$ \\
\hline G & LT & $\begin{array}{l}-58 F \\
-50 C\end{array}$ & $\begin{array}{l}-64 \\
-53\end{array}$ & $\begin{array}{l}-30 \\
-34\end{array}$ & $\begin{array}{l}-20 \\
-29\end{array}$ \\
\hline G & TL & $\begin{array}{l}-46 \\
-43\end{array}$ & $\begin{array}{l}-50 \\
-46\end{array}$ & $\begin{array}{l}-17 \\
-27\end{array}$ & \\
\hline U & LT & $\begin{array}{l}-47 \\
-44\end{array}$ & $\begin{array}{l}-46 \\
-43\end{array}$ & $\begin{array}{r}.7 \\
.22\end{array}$ & $\begin{array}{l}-40 \\
-40\end{array}$ \\
\hline U & TL & $\begin{array}{l}-42 \\
-41\end{array}$ & $\begin{array}{l}-46 \\
-43\end{array}$ & $\begin{array}{r}4 \\
16\end{array}$ & \\
\hline$S$ & LT & $\begin{array}{l}66 \\
19\end{array}$ & $\begin{array}{l}50 \\
10\end{array}$ & $\begin{array}{r}111 \\
44\end{array}$ & $\begin{array}{l}30 \\
-1\end{array}$ \\
\hline$S$ & TL & $\begin{array}{l}67 \\
19\end{array}$ & $\begin{array}{r}44 \\
7\end{array}$ & $\begin{array}{r}100 \\
38\end{array}$ & \\
\hline
\end{tabular}




\section{$\underline{\text { APPENDIX A }}$}

\section{Limitations Required for a Valid Test}

As discussed in detail by Server(3) the following limitations need to be satisfied to ensure acceptable load and available energy values:

1. $t \geq 3 \tau$

where $t$ is the time of any event being considered, and $\tau$ is related to the period of inertial oscillations in the contact load between tup and specimen. $\tau$ is predicted empirically for $\mathrm{S} / \mathrm{W}=4$ to be

$$
\tau=3.36\left(\mathrm{~W} / \mathrm{S}_{0}\right)\left(\mathrm{EBC}_{\mathrm{S}}\right)^{1 / 2}
$$

where $W$ is specimen width, $S$ is support span, $B$ is specimen thickness, $S_{0}$ is speed of sound in the specimen, $E$ is Young's Modulus and $C_{S}$ is specimen compliance. (See Appendix B.)

2. $t_{M} \geq 1.1 T_{R}$

where $T_{R}$ is the frequency response time of the instrumentation and is given by

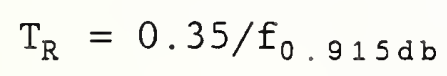

where $f_{0.915 d B}$ is the frequency at a $0.915 \mathrm{db}$ attenuation (10\% voltage attenuation) of a sine wave superimposed on the output of the strain gauge bridge circuit.

3. $\mathrm{T}_{\mathrm{R}} \geq 1.4 \tau$

where $T_{R}$ and $\tau$ are defined as in equation Al-A4. Specifying a minimum $T_{R}$ for the curve fitting of the oscillations reduces the amplitude of the oscillations so that the disparity between tup contact load and the effective minimum load is minimal.

4. $U_{0} \geq 3 E_{M}$

where $U_{\circ}$ is the total available energy at impact (section 4.1.3.) and $E_{M}$ is the energy absorbed by the specimen at maximum load. This requirement is based on minimizing the reduction to hammer velocity during the period needed to reach maximum load. 


\section{APPENDIX B}

\section{Compliance Calculations}

For each test specimen the compliance of the total system $\left(C_{T}\right)$ and that of the specimen $\left(C_{S}\right)$ were calculated. Subtracting $C_{S}$ from $C_{I}$ gave the machine compliance $\left(C_{M}\right)$.

Server(3) gives an equation for the total system complicance calculated at general yield and corrected for the decrease in velocity through general yield:

$$
C_{T}=\left(V_{0} t_{G Y} / P_{G Y}\right)-\left(V_{0}^{2} t_{G Y} / 8 E_{0}\right)
$$

where $V_{0}$ is the impact velocity, $t_{G Y}$ is time to general yield and $P_{G Y}$ is load at general yield. For typical values of $V_{O}, t_{G Y}$, and $E_{0}$ used in the present tests the second term of equation B1 is of the order of $0.1 \%$ of the first term and is thus not considered significant.

The specimen compliance $C_{S}$ was calculated from

$$
C_{S}=72[f(a / W)+0.215(1-\nu)] /(E B)
$$

where $E$ is Young's Modulus, $B$ is specimen thickness and $f(a / W)$ is given by

$$
\begin{gathered}
1.86(\mathrm{a} / \mathrm{W})^{2}-3.95(\mathrm{a} / \mathrm{W})^{3}+16.4(\mathrm{a} / \mathrm{W})^{4}-37.2(\mathrm{a} / \mathrm{W})^{5}+77.6(\mathrm{a} / \mathrm{W})^{6} \\
-127(\mathrm{a} / \mathrm{W})^{7}+173(\mathrm{a} / \mathrm{W})^{8}-144(\mathrm{a} / \mathrm{W})^{9}+66.6(\mathrm{a} / \mathrm{W})^{2}
\end{gathered}
$$

The machine compliance $C_{M}$ was obtained from

$$
C_{M}=C_{I}-C_{S}
$$

Values of $C_{M}, C_{T}, C_{S}$ are tabulated in Appendix D, Tables D3, 6, 9, 12, 15, and 18. 


\section{APPENDIX $C$}

Values of the Function $h(a / W)$ Used to Calculate $K_{I D}$

\begin{tabular}{llll}
$\mathrm{a} / \mathrm{W}$ & $\underline{\mathrm{h}(\mathrm{a} / \mathrm{W})}$ & $\underline{\mathrm{a} / \mathrm{W}}$ & $\mathrm{h}(\mathrm{a} / \mathrm{W})$ \\
0.450 & 36.86 & 0.520 & 45.92 \\
0.455 & 37.41 & 0.525 & 46.70 \\
0.460 & 39.98 & 0.530 & 47.49 \\
0.465 & 38.55 & 0.535 & 48.31 \\
0.470 & 39.15 & 0.540 & 49.14 \\
0.475 & 39.75 & 0.545 & 50.00 \\
0.480 & 40.37 & 0.550 & 50.88 \\
0.485 & 41.01 & 0.555 & 51.78 \\
0.490 & 41.66 & & \\
0.495 & 42.33 & & \\
0.500 & 43.01 & & \\
0.505 & 43.71 & & \\
0.510 & 44.43 & & \\
0.515 & 45.17 & & \\
\hline & & &
\end{tabular}


Table D1. Raw Data for Instrumented Impact Evaluation of Precracked Charpy Specimens, Plate $G$, Orientation LT

\begin{tabular}{|c|c|c|c|c|c|c|c|c|}
\hline \multirow{4}{*}{$\begin{array}{c}\text { Specimen } \\
\text { Code }\end{array}$} & \multirow{4}{*}{$\begin{array}{c}\text { Test } \\
\text { Temperature } \\
\text { F } \\
\text { C } \\
\end{array}$} & \multirow{3}{*}{$\begin{array}{c}\text { Dial } \\
\text { Energy } \\
\text { ft-lbf }\end{array}$} & \multicolumn{2}{|c|}{ Loads } & \multirow{2}{*}{\multicolumn{2}{|c|}{ Times }} & \multicolumn{2}{|c|}{ nitiation } \\
\hline & & & \multirow{3}{*}{$\begin{array}{c}P_{G Y} \\
I b f \\
N\end{array}$} & \multirow{3}{*}{$\begin{array}{c}\mathrm{P}_{\mathrm{M}} \\
\mathrm{lbf} \\
\mathrm{N}\end{array}$} & & & Energy & \\
\hline & & & & & $t_{G X}$ & $t_{M}$ & ft-lbf & \\
\hline & & $\mathrm{J}$ & & & $\mathrm{ms}$ & $\mathrm{ms}$ & $\mathrm{J}$ & $a / w$ \\
\hline \multirow[t]{2}{*}{ GL6 } & -20 & 14.5 & 1412 & 1472 & 0.19 & 0.22 & 0.8 & 0.48 \\
\hline & -29 & 19.7 & 6282 & 6549 & & & 1.0 & \\
\hline \multirow[t]{2}{*}{ GL11 } & -10 & 20.4 & 1338 & 1422 & 0.18 & 0.79 & 4.8 & 0.50 \\
\hline & -23 & 27.7 & 5951 & 6324 & & & 6.5 & \\
\hline \multirow[t]{2}{*}{ GL4 } & -10 & 23.6 & 1301 & 1437 & 0.25 & 1.12 & 6.6 & 0.50 \\
\hline & -23 & 32.0 & 5786 & 6391 & & & 8.9 & \\
\hline \multirow[t]{2}{*}{ GL2 } & 0 & 18.5 & 1351 & 1486 & 0.17 & 0.74 & 4.7 & 0.48 \\
\hline & -18 & 25.1 & 6010 & 6624 & & & 6.3 & \\
\hline \multirow[t]{2}{*}{ GL8 } & 15 & 23.5 & 1312 & 1450 & 0.17 & 0.80 & 4.9 & 0.49 \\
\hline & -9 & 31.9 & 5834 & 6448 & & & 6.7 & \\
\hline
\end{tabular}


Table D2. Results of Instrumented Impact Evaluation of Precracked Charpy Specimens, Plate G, Orientation LT

\begin{tabular}{|c|c|c|c|c|c|c|c|}
\hline $\begin{array}{l}\text { Specimen } \\
\text { Code }\end{array}$ & $\begin{array}{c}\text { Test } \\
\text { Temp. } \\
\text { F } \\
C \\
\end{array}$ & $\begin{array}{l}\text { Dynamic } \\
\text { Yield } \\
\text { Stress } \\
\mathrm{ksi} \\
\mathrm{MPa} \\
\end{array}$ & Total & $\begin{array}{l}\text { rmaliz } \\
\text { nergit } \\
-\operatorname{lb} f / \\
\mathrm{KJ} / \mathrm{M}^{2} \\
\text { Init }\end{array}$ & Prop. & $\begin{array}{c}\text { Eracture } \\
\text { Toughness } \\
\text { ksi/in } \\
\mathrm{MPa} / \mathrm{m} \\
\mathrm{K}_{\mathrm{ID}} \mathrm{K}_{\mathrm{JD}}\end{array}$ & $\begin{array}{c}\text { Stress } \\
\text { Intensity } \\
\text { Rate } \\
\mathrm{ksi} / \mathrm{in} / \mathrm{s} \\
\mathrm{MPa} / \mathrm{m} / \mathrm{s} \\
\end{array}$ \\
\hline GL6 & $\begin{array}{l}-20 \\
-29\end{array}$ & $\begin{array}{l}113.1 \\
779.7\end{array}$ & $\begin{array}{r}2175 \\
381\end{array}$ & $\begin{array}{l}56 \\
10\end{array}$ & $\begin{array}{r}2119 \\
371\end{array}$ & $\begin{array}{l}58.5 \\
64.3\end{array}$ & $\begin{array}{l}0.26 \mathrm{E} 6 \\
0.29 \mathrm{E} 6\end{array}$ \\
\hline GL11 & $\begin{array}{l}-10 \\
-23\end{array}$ & $\begin{array}{l}112.6 \\
776.4\end{array}$ & $\begin{array}{r}3138 \\
550\end{array}$ & $\begin{array}{l}689 \\
121\end{array}$ & $\begin{array}{r}2449 \\
429\end{array}$ & $\begin{array}{l}204.2 \\
224.4\end{array}$ & $\begin{array}{l}0.26 \mathrm{E} 6 \\
0.28 \mathrm{E} 6\end{array}$ \\
\hline GL4 & $\begin{array}{l}-10 \\
-23\end{array}$ & $\begin{array}{l}109.5 \\
754.9\end{array}$ & $\begin{array}{r}3630 \\
636\end{array}$ & $\begin{array}{l}908 \\
159\end{array}$ & $\begin{array}{r}2722 \\
477\end{array}$ & $\begin{array}{l}234.4 \\
257.6\end{array}$ & $\begin{array}{l}0.21 E 6 \\
0.23 E 6\end{array}$ \\
\hline GL2 & $\begin{array}{r}0 \\
-18\end{array}$ & $\begin{array}{l}108.2 \\
746.0\end{array}$ & $\begin{array}{r}2776 \\
486\end{array}$ & $\begin{array}{l}650 \\
114\end{array}$ & $\begin{array}{r}2126 \\
372\end{array}$ & $\begin{array}{l}198.1 \\
217.7\end{array}$ & $\begin{array}{l}0.27 E 6 \\
0.29 E 6\end{array}$ \\
\hline GL8 & $\begin{array}{l}15 \\
-9\end{array}$ & $\begin{array}{l}107.1 \\
738.7\end{array}$ & $\begin{array}{c}3561 . \\
624\end{array}$ & $\begin{array}{l}694 \\
121\end{array}$ & $\begin{array}{r}2867 \\
502\end{array}$ & $\begin{array}{l}204.4 \\
224.7\end{array}$ & $\begin{array}{l}0.25 \mathrm{E} 6 \\
0.28 \mathrm{E} 6\end{array}$ \\
\hline
\end{tabular}


Table D3. Young's Modulus and Compliance Values for Plate G, Orientation LT

\begin{tabular}{|c|c|c|c|c|c|}
\hline Specimen & $\begin{array}{l}\text { Temp } \\
\text { F } \\
\text { C }\end{array}$ & $\begin{array}{l}\text { YM } \\
k s i \times 10^{3} \\
M P a \times 10^{3}\end{array}$ & $\begin{array}{c}\mathrm{C}_{\frac{T}{1}} \\
\mathrm{in}-1 \mathrm{bf^{-1 }} \times 10^{-6} \\
\mathrm{mN}^{-1} \times 10^{-8}\end{array}$ & $\begin{array}{c}\mathrm{C}_{\mathrm{S}} \\
\mathrm{in}-1 \mathrm{bf^{-1 }} \times 10^{-6} \\
\mathrm{mN}^{-1} \times 10^{-8}\end{array}$ & $\begin{aligned} & \mathrm{C}_{\mathrm{M}} \\
\mathrm{in}-1 \mathrm{lb} \mathrm{f}^{-1} & \times 10^{-6} \\
\mathrm{mN}^{-1} & \times 10^{-8}\end{aligned}$ \\
\hline GL6 & $\begin{array}{l}-20 \\
-29\end{array}$ & $\begin{array}{r}30 \\
207\end{array}$ & $\begin{array}{l}8.8 \\
5.0\end{array}$ & $\begin{array}{l}4.5 \\
2.6\end{array}$ & $\begin{array}{l}4.3 \\
2.5\end{array}$ \\
\hline GL11 & $\begin{array}{l}-10 \\
-23\end{array}$ & $\begin{array}{r}30 \\
207\end{array}$ & $\begin{array}{l}8.8 \\
5.0\end{array}$ & $\begin{array}{l}4.7 \\
2.7\end{array}$ & $\begin{array}{l}4.1 \\
2.3\end{array}$ \\
\hline GL4 & $\begin{array}{l}-10 \\
-23\end{array}$ & $\begin{array}{r}30 \\
207\end{array}$ & $\begin{array}{r}13.0 \\
7.4\end{array}$ & $\begin{array}{l}4.7 \\
2.7\end{array}$ & $\begin{array}{l}7.9 \\
4.5\end{array}$ \\
\hline GL2 & $\begin{array}{r}0 \\
-17\end{array}$ & $\begin{array}{r}30 \\
207\end{array}$ & $\begin{array}{l}8.2 \\
4.7\end{array}$ & $\begin{array}{l}4.5 \\
2.6\end{array}$ & $\begin{array}{l}3.7 \\
2.1\end{array}$ \\
\hline GL8 & $\begin{array}{l}15 \\
-9\end{array}$ & $\begin{array}{r}30 \\
207\end{array}$ & $\begin{array}{l}8.5 \\
4.8\end{array}$ & $\begin{array}{l}4.6 \\
2.6\end{array}$ & $\begin{array}{l}3.9 \\
2.2\end{array}$ \\
\hline
\end{tabular}


Table D4. Raw Data for Instrumented Impact Evaluation of Precracked Charpy Specimens, Plate G, Orientation TL

\begin{tabular}{|c|c|c|c|c|c|c|c|c|}
\hline & Test & Dial & & & & & nitiati & \\
\hline & Temperature & Energy & $P_{G Y}$ & $\mathrm{P}_{M}$ & Tin & & Energy & \\
\hline Specimen & $F$ & $f t-l b f$ & $\operatorname{lbf}$ & $\operatorname{lbf}$ & $t_{G Y}$ & $t_{M}$ & $f t-l b f$ & \\
\hline Code & C & $\mathrm{J}$ & $\mathrm{N}$ & $\mathrm{N}$ & $\mathrm{ms}$ & $\mathrm{ms}$ & $\mathrm{J}$ & $a / \mathrm{W}$ \\
\hline GT29 & -60 & 4.2 & - & 912 & - & .140 & .2 & .50 \\
\hline & -51 & 5.7 & - & 4057 & & & .3 & \\
\hline GT12 & -60 & 5.3 & - & 1228 & - & .180 & .4 & .48 \\
\hline & -51 & 7.2 & - & 5463 & & & .6 & \\
\hline GT3 & -40 & 14.9 & 1314 & 1490 & .200 & .260 & .9 & .48 \\
\hline & -40 & 20.2 & 5846 & 6629 & & & 1.2 & \\
\hline GT8 & -40 & 6.5 & - & 1250 & - & .180 & .5 & .48 \\
\hline & -40 & 8.8 & - & 5560 & & & .7 & \\
\hline GT30 & -30 & 7.0 & - & 1174 & - & .180 & .4 & .51 \\
\hline & -34 & 9.5 & - & 5224 & & & .6 & \\
\hline GT9 & -20 & 14.7 & 1301 & 1423 & .210 & .260 & .8 & .48 \\
\hline & -29 & 19.9 & 5789 & 6332 & & & 1.1 & \\
\hline GT17 & -20 & 11.5 & 1274 & 1344 & .220 & .290 & .8 & .50 \\
\hline & -29 & 15.6 & 5667 & 5978 & & & 1.1 & \\
\hline GT20 & -10 & 14.4 & 1325 & 1325 & .210 & .210 & 1.0 & .50 \\
\hline & -23 & 19.5 & 5895 & 5895 & & & .14 & \\
\hline GT2 & -10 & 14.7 & 1242 & 1342 & .170 & .210 & .8 & .50 \\
\hline & -23 & 19.9 & 5525 & 5969 & & & 1.1 & \\
\hline GT36 & 0 & 13.7 & 1070 & 1170 & .170 & .440 & 2.1 & .53 \\
\hline & -18 & 18.6 & 4760 & 5204 & & & 2.8 & \\
\hline GT4 & 0 & 15.7 & - & 1417 & - & .190 & .8 & .48 \\
\hline & -18 & 21.3 & - & 6304 & & & 1.0 & \\
\hline GT14 & 15 & 14.8 & 1277 & 1289 & .190 & .520 & 2.6 & .49 \\
\hline & -9 & 20.1 & 5682 & 5736 & & & 3.5 & \\
\hline GT13 & 15 & 14.3 & 1255 & 1311 & .180 & .500 & 2.7 & .49 \\
\hline & -9 & 19.4 & 5582 & 5831 & & & 3.7 & \\
\hline GT23 & $\begin{array}{l}60 \\
16\end{array}$ & 14.1 & 1085 & 1187 & .160 & .510 & 2.5 & .51 \\
\hline & 16 & 19.1 & 4827 & 5281 & & & 3.4 & \\
\hline
\end{tabular}


Table D4. Continued.

\begin{tabular}{|c|c|c|c|c|c|c|c|c|}
\hline \multirow{4}{*}{$\begin{array}{c}\text { Specimen } \\
\text { Code }\end{array}$} & \multirow{4}{*}{$\begin{array}{c}\text { Test } \\
\text { Temperature } \\
\text { F } \\
\text { C }\end{array}$} & \multirow{4}{*}{$\begin{array}{c}\text { Dial } \\
\text { Energy } \\
\text { ft-lbf } \\
\mathrm{J}\end{array}$} & \multicolumn{2}{|c|}{ Loads } & \multirow{2}{*}{\multicolumn{2}{|c|}{ Times }} & \multicolumn{2}{|c|}{ Enitiation } \\
\hline & & & $P_{G Y}$ & $P_{M}$ & & & Energy & \\
\hline & & & lbf & $1 b f$ & $t_{G Y}$ & $t_{M}$ & $f t-1 b f$ & \\
\hline & & & $\mathrm{N}$ & $\mathrm{N}$ & $\mathrm{ms}$ & $\mathrm{ms}$ & $\mathrm{J}$ & $a / w$ \\
\hline \multirow[t]{2}{*}{ GT16 } & 90 & 14.6 & 1115 & 1191 & \multirow[t]{2}{*}{.180} & \multirow[t]{2}{*}{.670} & 3.3 & \multirow[t]{2}{*}{.50} \\
\hline & 32 & 19.8 & 4959 & 5297 & & & 4.5 & \\
\hline \multirow[t]{2}{*}{ GT5 } & 90 & 15.5 & 1182 & 1280 & \multirow[t]{2}{*}{.156} & \multirow[t]{2}{*}{.464} & 3.6 & \multirow[t]{2}{*}{.48} \\
\hline & 32 & 21.0 & 5257 & 5693 & & & 4.9 & \\
\hline
\end{tabular}


Table D5. Results of Instrumented Impact Evaluation of Precracked Charpy Specimens, Plate $G$, Orientation TL

\begin{tabular}{|c|c|c|c|c|c|c|c|c|}
\hline \multirow{2}{*}{$\begin{array}{c}\text { Specimen } \\
\text { Code }\end{array}$} & \multirow{2}{*}{$\begin{array}{l}\text { Test } \\
\text { Temp. } \\
\text { F } \\
\text { C } \\
\end{array}$} & \multirow[t]{2}{*}{$\begin{array}{l}\text { Dynamic } \\
\text { Yield } \\
\text { Stress } \\
\mathrm{ksi} \\
\mathrm{MPa} \\
\end{array}$} & \multicolumn{3}{|c|}{$\begin{array}{c}\text { Normalized } \\
\text { Energies } \\
\text { in- } 1 \mathrm{~b} f / \mathrm{in}^{2} \\
\mathrm{KJ} / \mathrm{M}^{2}\end{array}$} & \multicolumn{2}{|c|}{$\begin{array}{l}\text { Fracture } \\
\text { Toughness } \\
\mathrm{ksi} / \mathrm{in} \\
\mathrm{MPa} / \mathrm{m}\end{array}$} & \multirow[t]{2}{*}{$\begin{array}{c}\text { Stress } \\
\text { Intensity } \\
\text { Rate } \\
\mathrm{ksi} / \mathrm{in} / \mathrm{s} \\
\mathrm{MPa} / \mathrm{m} / \mathrm{s}\end{array}$} \\
\hline & & & Total & Init. & Prop. & $\underline{K}_{\text {I D }}$ & $\underline{K}_{J D}$ & \\
\hline \multirow[t]{2}{*}{ GT29 } & -60 & $>76.8$ & 646 & 23 & 624 & 38.8 & - & $0.28 \mathrm{E} 6$ \\
\hline & -51 & $>529.3$ & 113 & 4 & 109 & 42.7 & - & $0.30 E 6$ \\
\hline \multirow[t]{2}{*}{ GT12 } & -60 & $>97.4$ & 791 & 38 & 754 & 49.8 & - & $0.28 \mathrm{E} 6$ \\
\hline & -51 & $>671.5$ & 139 & 7 & 132 & 54.8 & - & $0.30 \mathrm{E} 6$ \\
\hline \multirow[t]{2}{*}{ GT3 } & -40 & 104.2 & 2225 & 85 & 2140 & - & 71.7 & $0.27 E 6$ \\
\hline & -40 & 718.5 & 390 & 15 & 375 & - & 78.8 & $0.30 E 6$ \\
\hline \multirow[t]{2}{*}{ GT8 } & -40 & $>99.1$ & 970 & 39 & 931 & 50.7 & - & $0.28 E 6$ \\
\hline & -40 & $>683.9$ & 170 & 7 & 163 & 55.7 & - & $0.31 E 6$ \\
\hline \multirow[t]{2}{*}{ GT30 } & -30 & $>101.9$ & 1093 & 40 & 1054 & 51.2 & - & $0.28 \mathrm{E} 6$ \\
\hline & -34 & $>702.7$ & $191^{\circ}$ & 7 & 185 & 56.3 & - & $0.31 \mathrm{E} 6$ \\
\hline \multirow[t]{2}{*}{ GT9 } & -20 & 103.2 & 2195 & 74 & 2120 & - & 67.1 & $0.26 \mathrm{E} 6$ \\
\hline & -29 & 711.5 & 384 & 13 & 371 & - & 73.7 & $0.28 E 6$ \\
\hline \multirow[t]{2}{*}{ GT17 } & -20 & 108.3 & 1778 & 79 & 1699 & - & 69.2 & $0.24 E 6$ \\
\hline & -29 & 746.9 & 311 & 14 & 298 & - & 76.1 & $0.26 \mathrm{E} 6$ \\
\hline \multirow[t]{2}{*}{ GT20 } & -10 & 112.7 & 2226 & 100 & 2126 & - & 77.8 & $0.37 \mathrm{E} 6$ \\
\hline & -23 & 776.9 & 390 & 18 & 372 & - & 85.5 & $0.41 \mathrm{E} 6$ \\
\hline \multirow[t]{2}{*}{ GT2 } & -10 & 104.5 & 2261 & 81 & 2180 & - & 69.9 & $0.33 \mathrm{E} 6$ \\
\hline & -23 & 720.8 & 396 & 14 & 382 & - & 76.8 & $0.36 \mathrm{E} 6$ \\
\hline \multirow[t]{2}{*}{ GT36 } & 0 & 102.1 & 2243 & 295 & 1948 & - & 133.5 & $0.30 E 6$ \\
\hline & -18 & 703.7 & 393 & 52 & 341 & - & 146.7 & $0.33 \mathrm{E} 6$ \\
\hline \multirow[t]{2}{*}{ GT4 } & 0 & $>111.3$ & 2333 & 50 & 2283 & 57.0 & - & $0.30 E 6$ \\
\hline & -18 & $>767.3$ & 408 & 9 & 400 & 62.7 & - & $0.33 \mathrm{E} 6$ \\
\hline \multirow[t]{2}{*}{ GT14 } & 15 & 105.4 & 2254 & 349 & 1905 & - & 145.0 & $0.28 \mathrm{E} 6$ \\
\hline & -9 & 726.6 & 395 & 61 & 334 & - & 159.3 & $0.31 \mathrm{E} 6$ \\
\hline \multirow[t]{2}{*}{ GT13 } & 15 & 104.6 & 2189 & 361 & 1828 & - & 147.5 & $0.29 \mathrm{E} 6$ \\
\hline & -9 & 720.9 & 383 & 63 & 320 & - & 162.1 & $0.32 E 6$ \\
\hline \multirow[t]{2}{*}{ GT23 } & 60 & 97.1 & 2237 & 361 & 1876 & - & 146.9 & $0.29 \mathrm{E} 6$ \\
\hline & 16 & 669.8 & 392 & 63 & 329 & - & 161.4 & $0.32 E 6$ \\
\hline
\end{tabular}


Table D5. Continued.

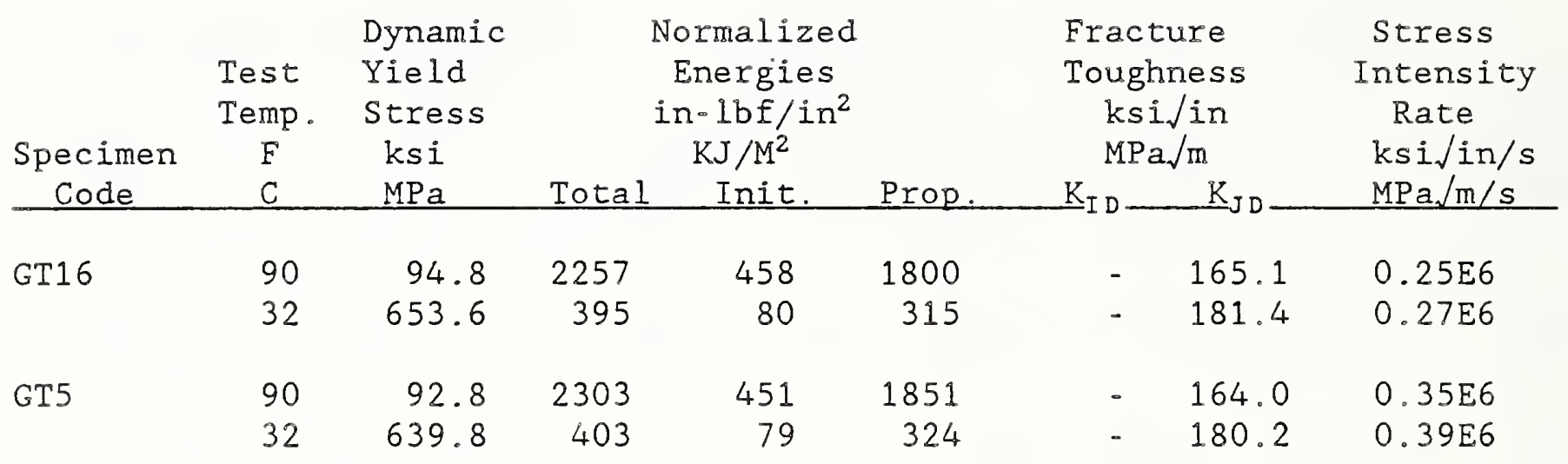


Table D6. Young's Modulus and Compliance Values for Plate G, Orientation IL

\begin{tabular}{|c|c|c|c|c|c|}
\hline Specimen & $\begin{array}{l}\text { Temp } \\
\text { F } \\
\text { C }\end{array}$ & $\begin{array}{l}\text { YM } \\
k s i \times 10^{3} \\
M P a \times 10^{3}\end{array}$ & $\begin{array}{c}\mathrm{C}_{\frac{T}{1}} \\
\mathrm{in-1bf^{-1 }} \times 10^{-6} \\
\mathrm{mN}^{-1} \times 10^{-8}\end{array}$ & $\begin{array}{c}\mathrm{C}_{S} \\
\mathrm{in}-1 \mathrm{lbf^{-1 }} \times 10^{-6} \\
\mathrm{mN}^{-1} \times 10^{-8}\end{array}$ & $\begin{array}{c}\mathrm{C}_{M} \\
\text { in- } 1 \mathrm{bf} \mathrm{f}^{-1} \times 10^{-6} \\
\mathrm{mN}^{-1} \times 10^{-8}\end{array}$ \\
\hline GT29 & $\begin{array}{l}-60 \\
-51\end{array}$ & $\begin{array}{r}33 \\
228\end{array}$ & $\begin{array}{l}7.7 \\
4.4\end{array}$ & $\begin{array}{l}4.3 \\
2.5\end{array}$ & $\begin{array}{l}3.4 \\
1.9\end{array}$ \\
\hline GT12 & $\begin{array}{l}-60 \\
-51\end{array}$ & $\begin{array}{r}33 \\
228\end{array}$ & $\begin{array}{l}7.4 \\
4.2\end{array}$ & $\begin{array}{l}4.0 \\
2.3\end{array}$ & $\begin{array}{l}3.4 \\
1.9\end{array}$ \\
\hline GT3 & $\begin{array}{l}-40 \\
-40\end{array}$ & $\begin{array}{r}30 \\
207\end{array}$ & $\begin{array}{l}7.7 \\
4.4\end{array}$ & $\begin{array}{l}4.4 \\
2.5\end{array}$ & $\begin{array}{l}3.3 \\
1.9\end{array}$ \\
\hline GT 8 & $\begin{array}{l}-40 \\
-40\end{array}$ & $\begin{array}{r}33 \\
228\end{array}$ & $\begin{array}{l}9.4 \\
5.4\end{array}$ & $\begin{array}{l}4.0 \\
2.3\end{array}$ & $\begin{array}{l}5.4 \\
3.1\end{array}$ \\
\hline GT30 & $\begin{array}{l}-30 \\
-34\end{array}$ & $\begin{array}{r}33 \\
228\end{array}$ & $\begin{array}{l}7.7 \\
4.4\end{array}$ & $\begin{array}{l}4.4 \\
2.5\end{array}$ & $\begin{array}{l}3.3 \\
1.9\end{array}$ \\
\hline GT9 & $\begin{array}{l}-20 \\
-29\end{array}$ & $\begin{array}{r}30 \\
207\end{array}$ & $\begin{array}{l}8.1 \\
4.6\end{array}$ & $\begin{array}{l}4.4 \\
2.5\end{array}$ & $\begin{array}{l}3.7 \\
2.1\end{array}$ \\
\hline GT17 & $\begin{array}{l}-20 \\
-29\end{array}$ & $\begin{array}{r}30 \\
207\end{array}$ & $\begin{array}{l}8.7 \\
5.0\end{array}$ & $\begin{array}{l}4.8 \\
2.7\end{array}$ & $\begin{array}{l}4.0 \\
2.3\end{array}$ \\
\hline GT20 & $\begin{array}{l}-10 \\
-23\end{array}$ & $\begin{array}{r}30 \\
207\end{array}$ & $\begin{array}{l}9.6 \\
5.5\end{array}$ & $\begin{array}{l}4.8 \\
2.7\end{array}$ & $\begin{array}{l}4.8 \\
2.7\end{array}$ \\
\hline GT2 & $\begin{array}{l}-10 \\
-20\end{array}$ & $\begin{array}{r}30 \\
207\end{array}$ & $\begin{array}{l}8.9 \\
5.1\end{array}$ & $\begin{array}{l}4.7 \\
2.7\end{array}$ & $\begin{array}{l}4.2 \\
2.4\end{array}$ \\
\hline GT36 & $\begin{array}{r}0 \\
-18\end{array}$ & $\begin{array}{r}30 \\
207\end{array}$ & $\begin{array}{r}10.0 \\
5.7\end{array}$ & $\begin{array}{l}5.4 \\
3.1\end{array}$ & $\begin{array}{l}5.0 \\
2.9\end{array}$ \\
\hline GT4 & $\begin{array}{r}0 \\
-18\end{array}$ & $\begin{array}{r}33 \\
223\end{array}$ & $\begin{array}{l}8.8 \\
5.0\end{array}$ & $\begin{array}{l}4.0 \\
2.3\end{array}$ & $\begin{array}{l}4.7 \\
2.7\end{array}$ \\
\hline GT14 & $\begin{array}{l}15 \\
-9\end{array}$ & $\begin{array}{r}30 \\
207\end{array}$ & $\begin{array}{l}9.0 \\
5.1\end{array}$ & $\begin{array}{l}4.6 \\
2.6\end{array}$ & $\begin{array}{l}4.4 \\
2.5\end{array}$ \\
\hline GT13 & $\begin{array}{l}15 \\
-9\end{array}$ & $\begin{array}{r}30 \\
207\end{array}$ & $\begin{array}{l}9.4 \\
5.4\end{array}$ & $\begin{array}{l}4.7 \\
2.7\end{array}$ & $\begin{array}{l}4.7 \\
2.7\end{array}$ \\
\hline GT23 & $\begin{array}{l}60 \\
16\end{array}$ & $\begin{array}{r}30 \\
207\end{array}$ & $\begin{array}{l}9.6 \\
5.5\end{array}$ & $\begin{array}{l}5.1 \\
2.9\end{array}$ & $\begin{array}{l}4.5 \\
2.6\end{array}$ \\
\hline GT16 & $\begin{array}{l}90 \\
32\end{array}$ & $\begin{array}{r}30 \\
207\end{array}$ & $\begin{array}{r}11.0 \\
6.3\end{array}$ & $\begin{array}{l}4.8 \\
2.7\end{array}$ & $\begin{array}{l}5.7 \\
3.2\end{array}$ \\
\hline GT5 & $\begin{array}{l}90 \\
32\end{array}$ & $\begin{array}{r}30 \\
207\end{array}$ & $\begin{array}{r}12.0 \\
6.8\end{array}$ & $\begin{array}{l}4.5 \\
2.6\end{array}$ & $\begin{array}{l}8.0 \\
4.6\end{array}$ \\
\hline
\end{tabular}


Table D7. Raw Data for Instrumented Impact Evaluation of Precracked Charpy Specimens, Plate U, Orientation LI

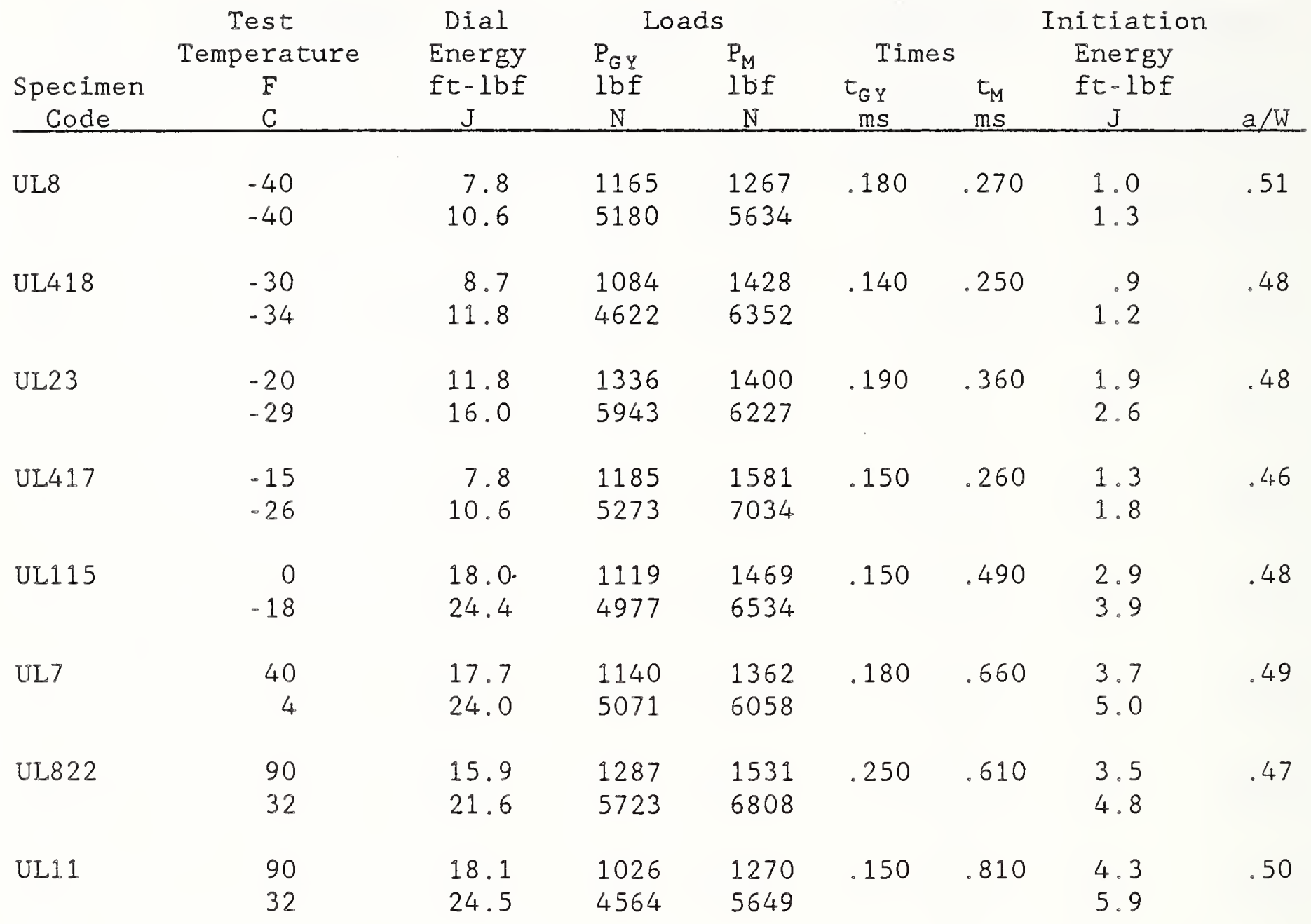


Table D8. Results of Instrumented Impact Evaluation of Precracked Charpy Specimens, Plate U, Orientation LT.

\begin{tabular}{|c|c|c|c|c|c|c|c|}
\hline Specimen & $\begin{array}{c}\text { Test } \\
\text { Temp. } \\
\text { F } \\
C\end{array}$ & $\begin{array}{l}\text { Dynamic } \\
\text { Yield } \\
\text { Stress } \\
\text { ksi } \\
\text { MPa }\end{array}$ & & $\begin{array}{l}\text { rmaliz } \\
\text { nergie } \\
\text { - } 1 \mathrm{~b} f / \mathrm{i} \\
\mathrm{KJ} / \mathrm{M}^{2} \\
\text { Init. }\end{array}$ & Prop & $\begin{array}{c}\text { Fracture } \\
\text { Toughness } \\
\text { ksi } \sqrt{ } \text { in } \\
\mathrm{MPa} / \mathrm{m}\end{array}$ & $\begin{array}{c}\text { Stress } \\
\text { Intensity } \\
\text { Rate } \\
\mathrm{ksi} / \mathrm{in} / \mathrm{s} \\
\mathrm{MPa} / \mathrm{m} / \mathrm{s}\end{array}$ \\
\hline UL8 & $\begin{array}{l}-40 \\
-40\end{array}$ & $\begin{array}{l}104.3 \\
718.8\end{array}$ & $\begin{array}{r}1237 \\
217\end{array}$ & $\begin{array}{r}118 \\
21\end{array}$ & $\begin{array}{r}1120 \\
196\end{array}$ & $\begin{array}{l}84.6 \\
92.9\end{array}$ & $\begin{array}{l}0.31 \mathrm{E} 6 \\
0.34 \mathrm{E} 6\end{array}$ \\
\hline UL418 & $\begin{array}{l}-30 \\
-34\end{array}$ & $\begin{array}{r}86.0 \\
592.7\end{array}$ & $\begin{array}{r}1299 \\
227\end{array}$ & $\begin{array}{l}95 \\
17\end{array}$ & $\begin{array}{r}1204 \\
211\end{array}$ & $\begin{array}{l}76.0 \\
83.5\end{array}$ & $\begin{array}{l}0.30 E 6 \\
0.33 E 6\end{array}$ \\
\hline UL23 & $\begin{array}{l}-20 \\
-29\end{array}$ & $\begin{array}{l}103.9 \\
716.3\end{array}$ & $\begin{array}{r}1745 \\
306\end{array}$ & $\begin{array}{r}22.1 \\
39\end{array}$ & $\begin{array}{r}1523 \\
267\end{array}$ & $\begin{array}{l}-115.8 \\
-\quad 127.3\end{array}$ & $\begin{array}{l}0.32 E 6 \\
0.35 E 6\end{array}$ \\
\hline UL412 & $\begin{array}{l}-15 \\
-26\end{array}$ & $\begin{array}{r}85.4 \\
588.9\end{array}$ & $\begin{array}{r}1110 \\
194\end{array}$ & $\begin{array}{r}124 \\
22\end{array}$ & $\begin{array}{l}986 \\
173\end{array}$ & $\begin{array}{l}86.6 \\
95.2\end{array}$ & $\begin{array}{l}0.33 E 6 \\
0.36 E 6\end{array}$ \\
\hline UL115 & $\begin{array}{r}0 \\
-18\end{array}$ & $\begin{array}{r}87.0 \\
599.9\end{array}$ & $\begin{array}{c}2661- \\
466\end{array}$ & $\begin{array}{r}368 \\
65\end{array}$ & $\begin{array}{r}2293 \\
402\end{array}$ & $\begin{array}{l}-149.1 \\
-\quad 163.9\end{array}$ & $\begin{array}{l}0.30 \mathrm{E} 6 \\
0.33 \mathrm{E} 6\end{array}$ \\
\hline UL7 & $\begin{array}{r}40 \\
4\end{array}$ & $\begin{array}{r}95.0 \\
655.0\end{array}$ & $\begin{array}{r}2709 \\
474\end{array}$ & $\begin{array}{r}494 \\
87\end{array}$ & $\begin{array}{r}2215 \\
388\end{array}$ & $\begin{array}{l}-172.3 \\
-\quad 189.3\end{array}$ & $\begin{array}{l}0.26 \mathrm{E} 6 \\
0.29 \mathrm{E} 6\end{array}$ \\
\hline UL822 & $\begin{array}{l}90 \\
32\end{array}$ & $\begin{array}{r}97.2 \\
670.2\end{array}$ & $\begin{array}{r}2317 \\
406\end{array}$ & $\begin{array}{r}395 \\
69\end{array}$ & $\begin{array}{r}1922 \\
337\end{array}$ & $\begin{array}{l}-153.5 \\
-\quad 168.6\end{array}$ & $\begin{array}{l}0.25 \mathrm{E} 6 \\
0.27 \mathrm{E} 6\end{array}$ \\
\hline UL11 & $\begin{array}{l}90 \\
32\end{array}$ & $\begin{array}{r}87.2 \\
601.5\end{array}$ & $\begin{array}{r}2798 \\
490\end{array}$ & $\begin{array}{l}621 \\
109\end{array}$ & $\begin{array}{r}2178 \\
381\end{array}$ & $\begin{array}{l}-\quad 192.3 \\
-\quad 211.3\end{array}$ & $\begin{array}{l}0.24 \mathrm{E} 6 \\
0.26 \mathrm{E} 6\end{array}$ \\
\hline
\end{tabular}


Table D9. Young's Modulus and Compliance Values for Plate U, Orientation LT

\begin{tabular}{|c|c|c|c|c|c|c|}
\hline Specimen & $\begin{array}{l}\text { Temp } \\
\text { F } \\
C\end{array}$ & $\begin{array}{l}\text { YM } \\
\text { ksi } \times 10^{3} \\
\text { MPa } \times 10^{3}\end{array}$ & $\underset{m N^{-1}}{i n-1 b f^{-}}$ & $\begin{array}{l}\times 10^{-6} \\
\times 10^{-8}\end{array}$ & $\begin{array}{c}\mathrm{C}_{\mathrm{S}} \\
\text { in- } \mathrm{LfF}^{-1} \times 10^{-6} \\
\mathrm{mN}^{-1} \times 10^{-8}\end{array}$ & $\begin{array}{c}\mathrm{C}_{\mathrm{M}} \\
\mathrm{in-1bf^{-1 }} \times 10^{-6} \\
\mathrm{mN}^{-1} \times 10^{-8}\end{array}$ \\
\hline \multirow[t]{2}{*}{ UL8 } & -40 & 30 & & 8.6 & 5.0 & 3.6 \\
\hline & -40 & 207 & & 4.9 & 2.9 & 2.1 \\
\hline \multirow[t]{2}{*}{ UL418 } & -30 & 30 & & 7.2 & 4.4 & 2.7 \\
\hline & -34 & 207 & & 4.1 & 2.5 & 1.5 \\
\hline \multirow[t]{2}{*}{ UL23 } & -20 & 30 & & 9.3 & 4.4 & 4.9 \\
\hline & -29 & 207 & & 5.3 & 2.5 & 2.8 \\
\hline \multirow[t]{2}{*}{ UL417 } & -15 & 30 & & 8.3 & 4.0 & 4.2 \\
\hline & -9 & 207 & & 4.7 & 2.3 & 2.4 \\
\hline \multirow[t]{2}{*}{ UL115 } & 0 & 30 & & 8.8 & 4.4 & 4.4 \\
\hline & -18 & 207 & . & 5.0 & 2.5 & 2.5 \\
\hline \multirow[t]{2}{*}{ UL7 } & 40 & 30 & & 10.0 & 4.7 & 5.6 \\
\hline & 4 & 207 & & 5.7 & 2.7 & 3.2 \\
\hline \multirow[t]{2}{*}{ UL822 } & 90 & 30 & & 13.0 & 4.3 & 8.4 \\
\hline & 32 & 207 & & 7.4 & 2.5 & 4.8 \\
\hline \multirow[t]{2}{*}{ UL11 } & 90 & 30 & & 9.6 & 4.8 & 4.7 \\
\hline & 32 & 207 & & 5.5 & 2.7 & 2.7 \\
\hline
\end{tabular}


Table D10. Raw Data for Instrumented Impact Evaluation of Precracked Charpy Specimens, Plate U, Orientation TL

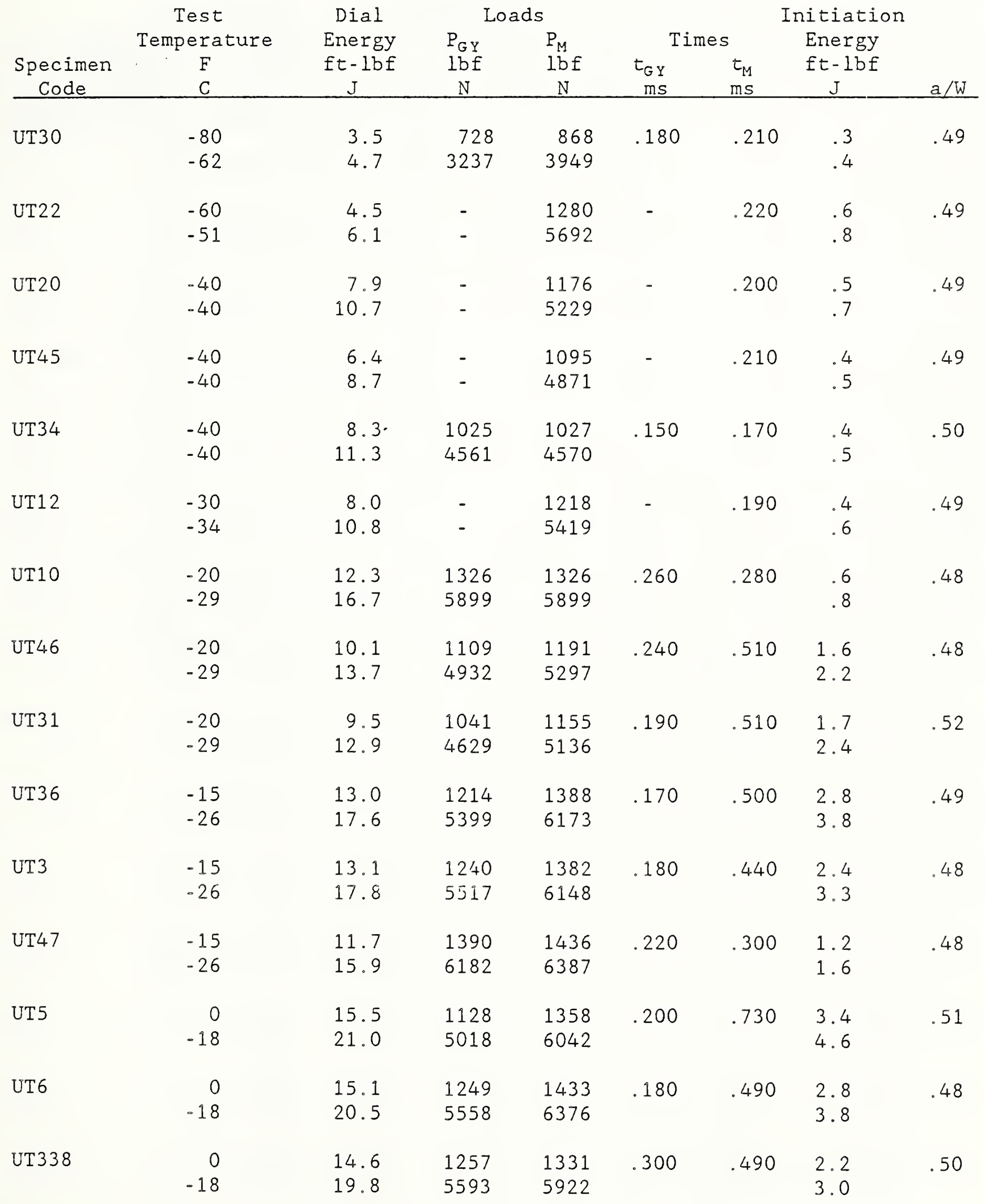


Table D10. Continued.

\begin{tabular}{|c|c|c|c|c|c|c|c|c|}
\hline \multirow{4}{*}{$\begin{array}{c}\text { Specimen } \\
\text { Code }\end{array}$} & \multirow{4}{*}{$\begin{array}{c}\text { Test } \\
\text { Temperature } \\
\text { F } \\
\text { C } \\
\end{array}$} & \multirow{4}{*}{$\begin{array}{c}\text { Dial } \\
\text { Energy } \\
\text { ft-lbf } \\
\mathrm{J}\end{array}$} & \multicolumn{2}{|c|}{ Loads } & \multirow{2}{*}{\multicolumn{2}{|c|}{ Times }} & & \\
\hline & & & $P_{G Y}$ & $P_{M}$ & & & \multirow{3}{*}{$\begin{array}{l}\text { Energy } \\
f t-1 b f \\
\mathrm{~J}\end{array}$} & \multirow[b]{3}{*}{$a / W$} \\
\hline & & & $\mathrm{lbf}$ & $\mathrm{lbf}$ & $t_{G Y}$ & $t_{M}$ & & \\
\hline & & & $\mathrm{N}$ & $\mathrm{N}$ & $\mathrm{ms}$ & $\mathrm{ms}$ & & \\
\hline \multirow[t]{2}{*}{ UT9 } & 15 & 15.8 & 1103 & 1271 & \multirow[t]{2}{*}{.170} & \multirow[t]{2}{*}{.650} & 3.5 & \multirow[t]{2}{*}{.52} \\
\hline & -9 & 21.4 & 4908 & 5655 & & & 4.7 & \\
\hline \multirow[t]{2}{*}{ UT17 } & 40 & 17.3 & 1178 & 1408 & \multirow[t]{2}{*}{.188} & \multirow[t]{2}{*}{.504} & 2.7 & \multirow[t]{2}{*}{.49} \\
\hline & 4 & 23.5 & 5239 & 6262 & & & 3.7 & \\
\hline \multirow[t]{2}{*}{ UT7 } & 40 & 17.0 & 1160 & 1360 & \multirow[t]{2}{*}{.180} & \multirow[t]{2}{*}{.660} & 3.7 & \multirow[t]{2}{*}{.49} \\
\hline & 4 & 23.0 & 5158 & 6048 & & & 5.0 & \\
\hline \multirow[t]{2}{*}{ UT1 } & 90 & 18.0 & 1493 & 1493 & \multirow[t]{2}{*}{.504} & \multirow[t]{2}{*}{.504} & 4.6 & \multirow[t]{2}{*}{.47} \\
\hline & 32 & 24.4 & 6643 & 6643 & & & 6.2 & \\
\hline \multirow[t]{2}{*}{ UT32 } & 90 & $17.0^{\circ}$ & 1313 & 1313 & \multirow[t]{2}{*}{.504} & \multirow[t]{2}{*}{.504} & 4.0 & \multirow[t]{2}{*}{.56} \\
\hline & 32 & 23.0 & 5840 & 5840 & & & 5.4 & \\
\hline \multirow[t]{2}{*}{ UT16 } & 135 & 17.0 & 1339 & 1339 & \multirow[t]{2}{*}{.498} & \multirow[t]{2}{*}{.498} & 4.1 & \multirow[t]{2}{*}{.49} \\
\hline & 57 & 23.0 & 5957 & 5957 & & & 5.6 & \\
\hline \multirow[t]{2}{*}{ UT8 } & 135 & 15.5 & 1172 & 1172 & \multirow[t]{2}{*}{.500} & \multirow[t]{2}{*}{.500} & 3.5 & \multirow[t]{2}{*}{.52} \\
\hline & 57 & 21.0 & 5212 & 5212 & & & 4.7 & \\
\hline
\end{tabular}


Table D11. Results of Instrumented Impact Evaluation of Precracked Charpy Specimens, Plate U, Orientation TL

\begin{tabular}{|c|c|c|c|c|c|c|c|c|}
\hline $\begin{array}{l}\text { Specimen } \\
\text { Code }\end{array}$ & $\begin{array}{c}\text { Test } \\
\text { Temp. } \\
\text { F } \\
C \\
\end{array}$ & $\begin{array}{l}\text { Dynamic } \\
\text { Yield } \\
\text { Stress } \\
\text { ksi } \\
\mathrm{MPa} \\
\end{array}$ & Total & $\begin{array}{l}\text { rmaliz } \\
\text { nergie } \\
-\operatorname{lbf} / \mathrm{i} \\
\mathrm{KJ} / \mathrm{M}^{2} \\
\text { Init. }\end{array}$ & Prop. & $\begin{array}{r}\text { Frac } \\
\text { Toug } \\
k s \\
M P \\
\mathrm{~K}_{\text {ID }}\end{array}$ & $\begin{array}{l}\text { cure } \\
\text { aness } \\
\text { i. in } \\
a_{\text {m }} \\
\mathrm{K}_{\mathrm{JD}}\end{array}$ & $\begin{array}{c}\text { Stress } \\
\text { Intensity } \\
\text { Rate } \\
\mathrm{ksi} / \mathrm{in} / \mathrm{s} \\
\mathrm{MPa} / \mathrm{m} / \mathrm{s} \\
\end{array}$ \\
\hline UT30 & $\begin{array}{l}-80 \\
-62\end{array}$ & $\begin{array}{r}60.6 \\
418.2\end{array}$ & $\begin{array}{r}536 \\
94\end{array}$ & $\begin{array}{l}8 \\
1\end{array}$ & $\begin{array}{r}528 \\
92\end{array}$ & - & $\begin{array}{l}22.3 \\
24.5\end{array}$ & $\begin{array}{l}0.11 \mathrm{E} 6 \\
0.12 \mathrm{E} 6\end{array}$ \\
\hline UT22 & $\begin{array}{l}-60 \\
-51\end{array}$ & $\begin{array}{l}>103.5 \\
>713.5\end{array}$ & $\begin{array}{l}678 \\
119\end{array}$ & $\begin{array}{r}42 \\
7\end{array}$ & $\begin{array}{l}636 \\
111\end{array}$ & $\begin{array}{l}52.7 \\
58.0\end{array}$ & - & $\begin{array}{l}0.24 E 6 \\
0.26 E 6\end{array}$ \\
\hline UT20 & $\begin{array}{l}-40 \\
-40\end{array}$ & $\begin{array}{l}>97.0 \\
>668.7\end{array}$ & $\begin{array}{r}1203 \\
211\end{array}$ & $\begin{array}{r}37 \\
6\end{array}$ & $\begin{array}{r}1166 \\
204\end{array}$ & $\begin{array}{l}49.2 \\
54.1\end{array}$ & - & $\begin{array}{l}0.25 \mathrm{E} 6 \\
0.27 \mathrm{E} 6\end{array}$ \\
\hline UT45 & $\begin{array}{l}-40 \\
-40\end{array}$ & $\begin{array}{l}>89.4 \\
>616.7\end{array}$ & $\begin{array}{l}970 \\
170\end{array}$ & $\begin{array}{r}31 \\
6\end{array}$ & $\begin{array}{l}938 \\
164\end{array}$ & $\begin{array}{l}45.5 \\
50.0\end{array}$ & - & $\begin{array}{l}0.22 E 6 \\
0.24 E 6\end{array}$ \\
\hline UT34 & $\begin{array}{l}-40 \\
-40\end{array}$ & $\begin{array}{r}87.2 \\
601.2\end{array}$ & $\begin{array}{c}1283 \\
225\end{array}$ & $\begin{array}{r}23 \\
4\end{array}$ & $\begin{array}{r}1260 \\
221\end{array}$ & - & $\begin{array}{l}37.6 \\
41.4\end{array}$ & $\begin{array}{l}0.22 \mathrm{E} 6 \\
0.24 \mathrm{E} 6\end{array}$ \\
\hline UT12 & $\begin{array}{l}-30 \\
-34\end{array}$ & $\begin{array}{l}>100.5 \\
>692.9\end{array}$ & $\begin{array}{r}1218 \\
213\end{array}$ & $\begin{array}{r}40 \\
7\end{array}$ & $\begin{array}{r}1179 \\
206\end{array}$ & $\begin{array}{l}51.0 \\
56.1\end{array}$ & - & $\begin{array}{l}0.27 E 6 \\
0.30 E 6\end{array}$ \\
\hline UT10 & $\begin{array}{l}-20 \\
-29\end{array}$ & $\begin{array}{l}105.2 \\
725.1\end{array}$ & $\begin{array}{r}1836 \\
322\end{array}$ & $\begin{array}{r}29 \\
5\end{array}$ & $\begin{array}{r}1808 \\
317\end{array}$ & - & $\begin{array}{l}41.6 \\
45.7\end{array}$ & $\begin{array}{l}0.15 \mathrm{E} 6 \\
0.16 \mathrm{E} 6\end{array}$ \\
\hline UT46 & $\begin{array}{l}-20 \\
-29\end{array}$ & $\begin{array}{r}86.2 \\
594.5\end{array}$ & $\begin{array}{r}1493 \\
262\end{array}$ & $\begin{array}{r}181 \\
32\end{array}$ & $\begin{array}{r}1312 \\
230\end{array}$ & - & $\begin{array}{l}104.8 \\
115.2\end{array}$ & $\begin{array}{l}0.20 \mathrm{E} 6 \\
0.22 \mathrm{E} 6\end{array}$ \\
\hline UT31 & $\begin{array}{l}-20 \\
-29\end{array}$ & $\begin{array}{r}94.1 \\
649.0\end{array}$ & $\begin{array}{r}1515 \\
265\end{array}$ & $\begin{array}{l}242 \\
42\end{array}$ & $\begin{array}{r}1273 \\
223\end{array}$ & - & $\begin{array}{l}121.1 \\
133.0\end{array}$ & $\begin{array}{l}0.24 E 6 \\
0.26 E 6\end{array}$ \\
\hline UT36 & $\begin{array}{l}-15 \\
-26\end{array}$ & $\begin{array}{l}101.1 \\
697.4\end{array}$ & $\begin{array}{r}1990 \\
348\end{array}$ & $\begin{array}{r}375 \\
66\end{array}$ & $\begin{array}{r}1615 \\
283\end{array}$ & $\begin{array}{l}- \\
-\end{array}$ & $\begin{array}{l}150.6 \\
165.5\end{array}$ & $\begin{array}{l}0.30 E 6 \\
0.33 E 6\end{array}$ \\
\hline UT3 & $\begin{array}{l}-15 \\
-26\end{array}$ & $\begin{array}{r}98.3 \\
678.1\end{array}$ & $\begin{array}{r}1956 \\
343\end{array}$ & $\begin{array}{r}299 \\
52\end{array}$ & $\begin{array}{r}1656 \\
290\end{array}$ & - & $\begin{array}{l}134.6 \\
148.0\end{array}$ & $\begin{array}{l}0.30 \mathrm{E} 6 \\
0.33 \mathrm{E} 6\end{array}$ \\
\hline UT47 & $\begin{array}{l}-15 \\
-26\end{array}$ & $\begin{array}{l}108.1 \\
745.2\end{array}$ & $\begin{array}{r}1730 \\
303\end{array}$ & $\begin{array}{r}101 \\
18\end{array}$ & $\begin{array}{r}1629 \\
285\end{array}$ & - & $\begin{array}{l}78.2 \\
85.9\end{array}$ & $\begin{array}{l}0.26 \mathrm{E} 6 \\
0.28 \mathrm{E} 6\end{array}$ \\
\hline UT5 & $\begin{array}{r}0 \\
-18\end{array}$ & $\begin{array}{r}98.9 \\
682.1\end{array}$ & $\begin{array}{r}2433 \\
426\end{array}$ & $\begin{array}{r}468 \\
82\end{array}$ & $\begin{array}{r}1966 \\
344\end{array}$ & - & $\begin{array}{l}168.0 \\
184.7\end{array}$ & $\begin{array}{l}0.23 \mathrm{E} 6 \\
0.25 \mathrm{E} 6\end{array}$ \\
\hline UT6 & $\begin{array}{r}0 \\
-18\end{array}$ & $\begin{array}{r}98.1 \\
688.4\end{array}$ & $\begin{array}{r}2243 \\
393\end{array}$ & $\begin{array}{r}352 \\
62\end{array}$ & $\begin{array}{r}1892 \\
331\end{array}$ & - & $\begin{array}{l}145.7 \\
160.1\end{array}$ & $\begin{array}{l}0.30 E 6 \\
0.33 E 6\end{array}$ \\
\hline UT338 & $\begin{array}{r}0 \\
-18\end{array}$ & $\begin{array}{l}108.0 \\
744.7\end{array}$ & $\begin{array}{r}2269 \\
397\end{array}$ & $\begin{array}{r}224 \\
39\end{array}$ & $\begin{array}{r}2045 \\
358\end{array}$ & - & $\begin{array}{l}116.2 \\
127.7\end{array}$ & $\begin{array}{l}0.24 \mathrm{E} 6 \\
0.26 \mathrm{E} 6\end{array}$ \\
\hline
\end{tabular}


TABLE D11. CONTINUED

\begin{tabular}{|c|c|c|c|c|c|c|c|c|}
\hline $\begin{array}{c}\text { Specimen } \\
\text { Code }\end{array}$ & $\begin{array}{l}\text { Test } \\
\text { Temp. } \\
\text { F } \\
\text { C }\end{array}$ & $\begin{array}{l}\text { Dynamic } \\
\text { Yield } \\
\text { Stress } \\
\text { ksi } \\
\mathrm{MPa} \\
\end{array}$ & Total & $\begin{array}{l}\text { rmaliz } \\
\text { nergie } \\
-\mathrm{Ibf} / \mathrm{i} \\
\mathrm{KJ} / \mathrm{M}^{2} \\
\text { Init. }\end{array}$ & Prop. & $\begin{array}{l}\text { Fr } \\
\text { To } \\
\\
\mathrm{K}_{\mathrm{T}}\end{array}$ & $\begin{array}{l}\text { ire } \\
\text { hess } \\
\text { in } \\
\text { lm } \\
K_{\text {JD }}\end{array}$ & $\begin{array}{l}\text { Stress } \\
\text { Intensity } \\
\text { Rate } \\
\mathrm{ksi} / \mathrm{in} / \mathrm{s} \\
\mathrm{MPa} / \mathrm{m} / \mathrm{s}\end{array}$ \\
\hline UT9 & $\begin{array}{l}15 \\
-9\end{array}$ & $\begin{array}{r}99.8 \\
688.2\end{array}$ & $\begin{array}{r}2519 \\
441\end{array}$ & $\begin{array}{r}500 \\
88\end{array}$ & $\begin{array}{r}2020 \\
354\end{array}$ & - & $\begin{array}{l}173.5 \\
190.7\end{array}$ & $\begin{array}{l}0.27 E 6 \\
0.29 E 6\end{array}$ \\
\hline UT17 & $\begin{array}{r}40 \\
4\end{array}$ & $\begin{array}{r}98.2 \\
663.3\end{array}$ & $\begin{array}{r}2621 \\
459\end{array}$ & $\begin{array}{r}345 \\
60\end{array}$ & $\begin{array}{r}2277 \\
399\end{array}$ & $\begin{array}{l}- \\
-\end{array}$ & $\begin{array}{l}143.9 \\
158.1\end{array}$ & $\begin{array}{l}0.28 \mathrm{E} 6 \\
0.31 \mathrm{E} 6\end{array}$ \\
\hline UT7 & $\begin{array}{r}40 \\
4\end{array}$ & $\begin{array}{r}95.7 \\
659.6\end{array}$ & $\begin{array}{r}2589 \\
453\end{array}$ & $\begin{array}{r}498 \\
87\end{array}$ & $\begin{array}{r}2091 \\
366\end{array}$ & - & $\begin{array}{l}173.0 \\
190.1\end{array}$ & $\begin{array}{l}0.26 \mathrm{E} 6 \\
0.29 \mathrm{E} 6\end{array}$ \\
\hline UT1 & $\begin{array}{l}90 \\
32\end{array}$ & $\begin{array}{l}111.8 \\
770.5\end{array}$ & $\begin{array}{r}2611 \\
457\end{array}$ & $\begin{array}{l}588 \\
103\end{array}$ & $\begin{array}{r}2022 \\
354\end{array}$ & $\begin{array}{l}- \\
-\end{array}$ & $\begin{array}{l}187.2 \\
205.7\end{array}$ & $\begin{array}{l}0.37 \mathrm{E} 6 \\
0.41 \mathrm{E} 6\end{array}$ \\
\hline UT32 & $\begin{array}{l}90 \\
32\end{array}$ & $\begin{array}{l}112.8 \\
777.7\end{array}$ & $\begin{array}{r}2642 \\
463\end{array}$ & $\begin{array}{r}562 \\
98\end{array}$ & $\begin{array}{r}2080 \\
364\end{array}$ & $\begin{array}{l}- \\
-\end{array}$ & $\begin{array}{l}182.9 \\
201.0\end{array}$ & $\begin{array}{l}0.36 \mathrm{E} 6 \\
0.40 \mathrm{E} 6\end{array}$ \\
\hline UT16 & $\begin{array}{r}135 \\
57\end{array}$ & $\begin{array}{l}108.3 \\
746.8\end{array}$ & $\begin{array}{r}2563 \\
449\end{array}$ & $\begin{array}{r}561 \\
98\end{array}$ & $\begin{array}{r}2002 \\
351\end{array}$ & - & $\begin{array}{l}182.1 \\
200.1\end{array}$ & $\begin{array}{l}0.36 \mathrm{E} 6 \\
0.40 \mathrm{E} 6\end{array}$ \\
\hline UT8 & $\begin{array}{r}135 \\
57\end{array}$ & $\begin{array}{l}107.1 \\
738.4\end{array}$ & $\begin{array}{r}2485 \\
435\end{array}$ & $\begin{array}{r}509 \\
89\end{array}$ & $\begin{array}{r}1976 \\
346\end{array}$ & - & $\begin{array}{l}173.5 \\
190.6\end{array}$ & $\begin{array}{l}0.35 \mathrm{E} 6 \\
0.38 \mathrm{E} 6\end{array}$ \\
\hline
\end{tabular}


Table D12. Young's Modulus and Compliance Values for Plate U, Orientation TL

\begin{tabular}{|c|c|c|c|c|c|}
\hline Specimen & $\begin{array}{l}\text { Temp } \\
\text { F } \\
\text { C }\end{array}$ & $\begin{array}{l}\text { YM } \\
\text { ksi } \times 10^{3} \\
\text { MPa } \times 10^{3}\end{array}$ & $\begin{array}{c}\mathrm{C}_{\mathrm{T}} \\
\mathrm{in-1b \textrm {f } ^ { - 1 }} \times 10^{-6} \\
\mathrm{mN}^{-1} \times 10^{-8}\end{array}$ & $\begin{array}{c}\mathrm{C}_{S} \\
\mathrm{in}-1 \mathrm{bf^{-1 }} \times 10^{-6} \\
\mathrm{mN}^{-1} \times 10^{-8}\end{array}$ & $\begin{array}{c}\mathrm{C}_{M} \\
\text { in- }-1 b f^{-1} \times 10^{-8} \\
\mathrm{mN}^{-1} \times 10^{-8}\end{array}$ \\
\hline UT30 & $\begin{array}{l}-80 \\
-62\end{array}$ & $\begin{array}{r}31 \\
214\end{array}$ & $\begin{array}{r}12.0 \\
6.8\end{array}$ & $\begin{array}{l}4.6 \\
2.6\end{array}$ & $\begin{array}{l}7.9 \\
4.5\end{array}$ \\
\hline UT22 & $\begin{array}{l}-60 \\
-51\end{array}$ & $\begin{array}{r}33 \\
228\end{array}$ & $\begin{array}{l}8.7 \\
5.0\end{array}$ & $\begin{array}{l}4.1 \\
2.3\end{array}$ & $\begin{array}{l}4.6 \\
2.6\end{array}$ \\
\hline UT20 & $\begin{array}{l}-40 \\
-40\end{array}$ & $\begin{array}{r}33 \\
228\end{array}$ & $\begin{array}{l}8.6 \\
4.9\end{array}$ & $\begin{array}{l}4.2 \\
2.4\end{array}$ & $\begin{array}{l}4.4 \\
2.5\end{array}$ \\
\hline UT45 & $\begin{array}{l}-40 \\
-40\end{array}$ & $\begin{array}{r}33 \\
228\end{array}$ & $\begin{array}{r}11.0 \\
6.3\end{array}$ & $\begin{array}{l}4.2 \\
2.4\end{array}$ & $\begin{array}{l}6.5 \\
3.7\end{array}$ \\
\hline UT 34 & $\begin{array}{l}-40 \\
-40\end{array}$ & $\begin{array}{r}30 \\
207\end{array}$ & $\begin{array}{l}9.5 \\
5.4\end{array}$ & $\begin{array}{l}4.7 \\
2.7\end{array}$ & $\begin{array}{l}4.8 \\
2.7\end{array}$ \\
\hline UT12 & $\begin{array}{l}-30 \\
-34\end{array}$ & $\begin{array}{r}33 \\
228\end{array}$ & $\begin{array}{l}7.9 \\
4.5\end{array}$ & $\begin{array}{l}4.2 \\
2.4\end{array}$ & $\begin{array}{l}3.7 \\
2.1\end{array}$ \\
\hline UT10 & $\begin{array}{l}-20 \\
-29\end{array}$ & $\begin{array}{r}30 \\
207\end{array}$ & $\begin{array}{l}9.9 \\
5.6\end{array}$ & $\begin{array}{l}4.4 \\
2.5\end{array}$ & $\begin{array}{l}5.5 \\
3.1\end{array}$ \\
\hline UT46 & $\begin{array}{l}-20 \\
-29\end{array}$ & $\begin{array}{r}30 \\
207\end{array}$ & $\begin{array}{r}11.0 \\
6.3\end{array}$ & $\begin{array}{l}4.4 \\
2.5\end{array}$ & $\begin{array}{l}6.6 \\
3.8\end{array}$ \\
\hline UT31 & $\begin{array}{l}-20 \\
-29\end{array}$ & $\begin{array}{r}30 \\
207\end{array}$ & $\begin{array}{l}9.2 \\
5.2\end{array}$ & $\begin{array}{l}5.1 \\
2.9\end{array}$ & $\begin{array}{l}4.2 \\
2.4\end{array}$ \\
\hline UT36 & $\begin{array}{l}-15 \\
-26\end{array}$ & $\begin{array}{r}30 \\
207\end{array}$ & $\begin{array}{l}9.1 \\
5.2\end{array}$ & $\begin{array}{l}4.7 \\
2.7\end{array}$ & $\begin{array}{l}4.5 \\
2.6\end{array}$ \\
\hline UT3 & $\begin{array}{l}-15 \\
-26\end{array}$ & $\begin{array}{r}30 \\
207\end{array}$ & $\begin{array}{l}9.5 \\
5.7\end{array}$ & $\begin{array}{l}4.4 \\
2.5\end{array}$ & $\begin{array}{l}5.0 \\
2.9\end{array}$ \\
\hline UT47 & $\begin{array}{l}-15 \\
-26\end{array}$ & $\begin{array}{r}30 \\
207\end{array}$ & $\begin{array}{r}10.0 \\
5.7\end{array}$ & $\begin{array}{l}4.4 \\
2.5\end{array}$ & $\begin{array}{l}6.0 \\
3.4\end{array}$ \\
\hline UTS & $\begin{array}{r}0 \\
-17\end{array}$ & $\begin{array}{r}30 \\
207\end{array}$ & $\begin{array}{l}9.8 \\
5.6\end{array}$ & $\begin{array}{l}4.9 \\
2.8\end{array}$ & $\begin{array}{l}4.9 \\
2.8\end{array}$ \\
\hline UT6 & $\begin{array}{r}0 \\
-17\end{array}$ & $\begin{array}{r}30 \\
207\end{array}$ & $\begin{array}{l}9.4 \\
5.4\end{array}$ & $\begin{array}{l}4.4 \\
2.5\end{array}$ & $\begin{array}{l}5.0 \\
2.9\end{array}$ \\
\hline vT338 & $\begin{array}{r}0 \\
-17\end{array}$ & $\begin{array}{r}30 \\
207\end{array}$ & $\begin{array}{r}16.0 \\
9.1\end{array}$ & $\begin{array}{l}4.8 \\
2.7\end{array}$ & $\begin{array}{r}11.0 \\
6.3\end{array}$ \\
\hline
\end{tabular}


Table D12. Continued.

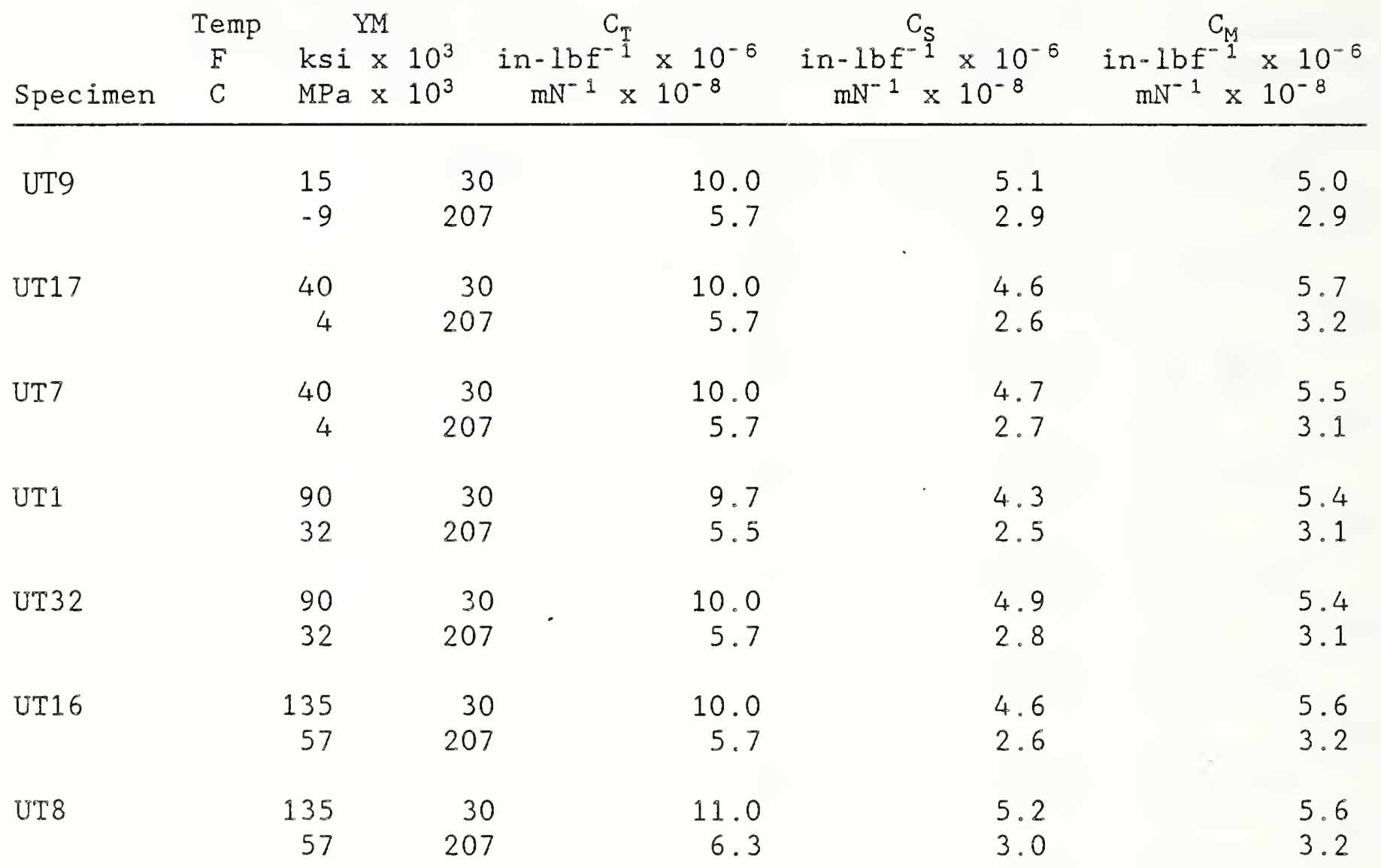


Table D13. Raw Data for Instrumented Impact Evaluation of Precracked Charpy Specimens, Plate S, Orientation LT

\begin{tabular}{|c|c|c|c|c|c|c|c|c|}
\hline $\begin{array}{l}\text { Specimen } \\
\text { Code } \\
\end{array}$ & $\begin{array}{c}\text { Test } \\
\text { Temperature } \\
\text { F } \\
\mathrm{C} \\
\end{array}$ & $\begin{array}{c}\text { Dial } \\
\text { Energy } \\
\text { ft-lbf } \\
\mathrm{J} \\
\end{array}$ & $\begin{array}{c}\quad I \\
P_{G Y} \\
I b f \\
N \\
\end{array}$ & $\begin{array}{l}s \\
\mathrm{P}_{\mathrm{M}} \\
\mathrm{lbf} \\
\mathrm{N} \\
\end{array}$ & $\begin{array}{c}\text { Ti } \\
t_{G Y} \\
m s\end{array}$ & $\begin{array}{l}t_{M} \\
m s \\
\end{array}$ & $\begin{array}{l}\text { Eitiatio } \\
\text { Energy } \\
\text { ft-lbf } \\
\mathrm{J}\end{array}$ & $a / w$ \\
\hline SL8 & $\begin{array}{r}110 \\
43\end{array}$ & $\begin{array}{l}12.9 \\
17.5\end{array}$ & $\begin{array}{r}884 \\
3932\end{array}$ & $\begin{array}{r}884 \\
3932\end{array}$ & - & .130 & $\begin{array}{l}.4 \\
.5\end{array}$ & .49 \\
\hline SL9 & $\begin{array}{r}135 \\
57\end{array}$ & $\begin{array}{l}21.3 \\
28.6\end{array}$ & $\begin{array}{l}1012 \\
4502\end{array}$ & $\begin{array}{l}1104 \\
4912\end{array}$ & .130 & .990 & $\begin{array}{l}4.5 \\
6.0\end{array}$ & .46 \\
\hline SL3 & $\begin{array}{r}135 \\
57\end{array}$ & $\begin{array}{l}15.7 \\
21.3\end{array}$ & $\begin{array}{r}761 \\
3383\end{array}$ & $\begin{array}{r}861 \\
3828\end{array}$ & .160 & .190 & $\begin{array}{l}.4 \\
.5\end{array}$ & .50 \\
\hline SL12 & $\begin{array}{r}160 \\
71\end{array}$ & $\begin{array}{l}21.2 \\
28.7\end{array}$ & $\begin{array}{r}842 \\
3744\end{array}$ & $\begin{array}{l}1046 \\
4652\end{array}$ & .150 & .980 & $\begin{array}{l}3.9 \\
5.3\end{array}$ & .49 \\
\hline SL1 & $\begin{array}{r}160 \\
71\end{array}$ & $\begin{array}{l}18.7 \\
25.4\end{array}$ & $\begin{array}{r}952 \\
4235\end{array}$ & $\begin{array}{r}952 \\
4235\end{array}$ & - & .490 & $\begin{array}{l}2.0 \\
2.7\end{array}$ & .52 \\
\hline SL5 & $\begin{array}{r}200 \\
93\end{array}$ & $\begin{array}{l}25.1 \\
34.0\end{array}$ & $\begin{array}{l}1191 \\
5300\end{array}$ & $\begin{array}{l}1191 \\
5300\end{array}$ & - & 1.250 & $\begin{array}{l}6.1 \\
8.2\end{array}$ & .48 \\
\hline SL2 & $\begin{array}{r}200 \\
93\end{array}$ & $\begin{array}{l}22.1 \\
30.0\end{array}$ & $\begin{array}{r}488 \\
4393\end{array}$ & $\begin{array}{r}488 \\
4393\end{array}$ & - & 1.030 & $\begin{array}{l}4.3 \\
5.9\end{array}$ & .51 \\
\hline
\end{tabular}


Table D14. Results of Instrumented Impact Evaluation of Precracked Charpy Specimens, Plate S, Orientation LT

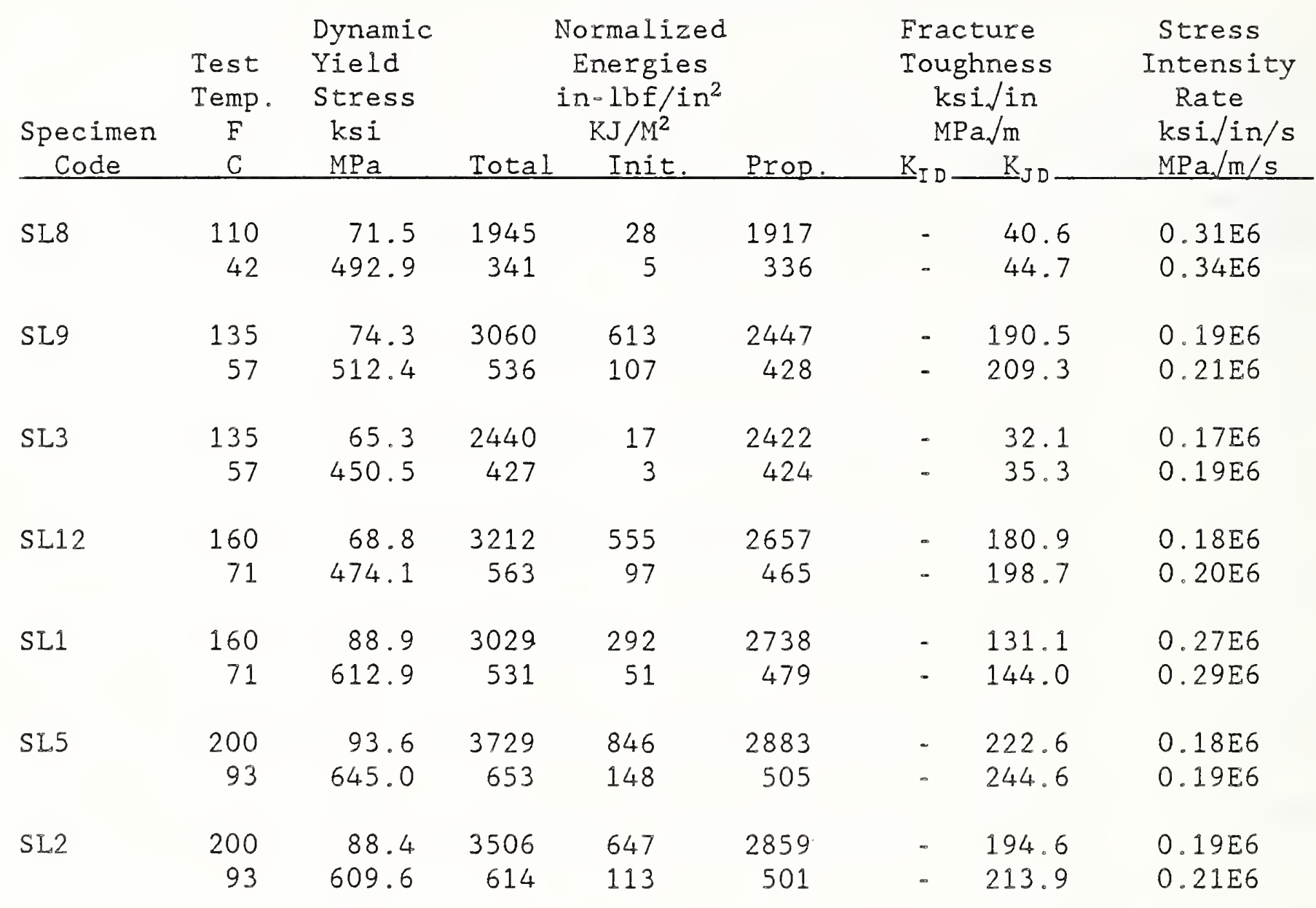


Table D15. Young's Modulus and Compliance Values for Plate S, Orientation LT

\begin{tabular}{|c|c|c|c|c|c|}
\hline Specimen & $\begin{array}{l}\text { Temp } \\
\text { F } \\
\text { C }\end{array}$ & $\begin{array}{l}\text { YM } \\
\text { ksi } \times 10^{3} \\
\mathrm{MPa} \times 10^{3}\end{array}$ & $\begin{array}{c}C_{T} \\
\text { in- } 1 b f^{-1} \times 10^{-6} \\
m N^{-1} \times 10^{-8}\end{array}$ & $\begin{array}{c}\mathrm{C}_{S} \\
\text { in- } 1 b f^{-1} \times 10^{-6} \\
\mathrm{mN}^{-1} \times 10^{-8}\end{array}$ & $\begin{array}{c}\mathrm{C}_{M} \\
\text { in- }-1 b f^{-1} \times 10^{-6} \\
\mathrm{mN}^{-1} \times 10^{-8}\end{array}$ \\
\hline SL8 & $\begin{array}{r}110 \\
43\end{array}$ & $\begin{array}{r}30 \\
207\end{array}$ & $\begin{array}{r}10.0 \\
5.7\end{array}$ & $\begin{array}{l}4.6 \\
2.6\end{array}$ & $\begin{array}{l}5.4 \\
3.1\end{array}$ \\
\hline SL9 & $\begin{array}{r}135 \\
57\end{array}$ & $\begin{array}{r}30 \\
207\end{array}$ & $\begin{array}{l}7.8 \\
4.4\end{array}$ & $\begin{array}{l}4.2 \\
2.4\end{array}$ & $\begin{array}{l}3.6 \\
2.1\end{array}$ \\
\hline SL3 & $\begin{array}{r}135 \\
57\end{array}$ & $\begin{array}{r}30 \\
207\end{array}$ & $\begin{array}{r}14.0 \\
8.0\end{array}$ & $\begin{array}{l}4.9 \\
2.8\end{array}$ & $\begin{array}{l}8.8 \\
5.0\end{array}$ \\
\hline SL12 & $\begin{array}{r}160 \\
71\end{array}$ & $\begin{array}{r}29 \\
200\end{array}$ & $\begin{array}{r}11.0 \\
6.3\end{array}$ & $\begin{array}{l}4.7 \\
2.7\end{array}$ & $\begin{array}{l}6.1 \\
3.5\end{array}$ \\
\hline SL1 & $\begin{array}{r}160 \\
71\end{array}$ & $\begin{array}{r}29 \\
200\end{array}$ & $\begin{array}{r}11.0 \\
6.3\end{array}$ & $\begin{array}{l}5.4 \\
3.1\end{array}$ & $\begin{array}{l}5.8 \\
3.3\end{array}$ \\
\hline SL5 & $\begin{array}{r}200 \\
93\end{array}$ & $\begin{array}{r}29 \\
200\end{array}$ & $\begin{array}{r}11.0 \\
6.3\end{array}$ & $\begin{array}{l}4.6 \\
2.6\end{array}$ & $\begin{array}{l}6.0 \\
3.4\end{array}$ \\
\hline SL2 & $\begin{array}{r}200 \\
93\end{array}$ & $\begin{array}{r}29 \\
200\end{array}$ & $\begin{array}{r}11.0 \\
6.3\end{array}$ & $\begin{array}{l}5.2 \\
3.0\end{array}$ & $\begin{array}{l}6.0 \\
3.4\end{array}$ \\
\hline
\end{tabular}


Table D16. Raw Data for Instrumented Impact Evaluation of Precracked Charpy Specimens, Plate S, Orientation TL

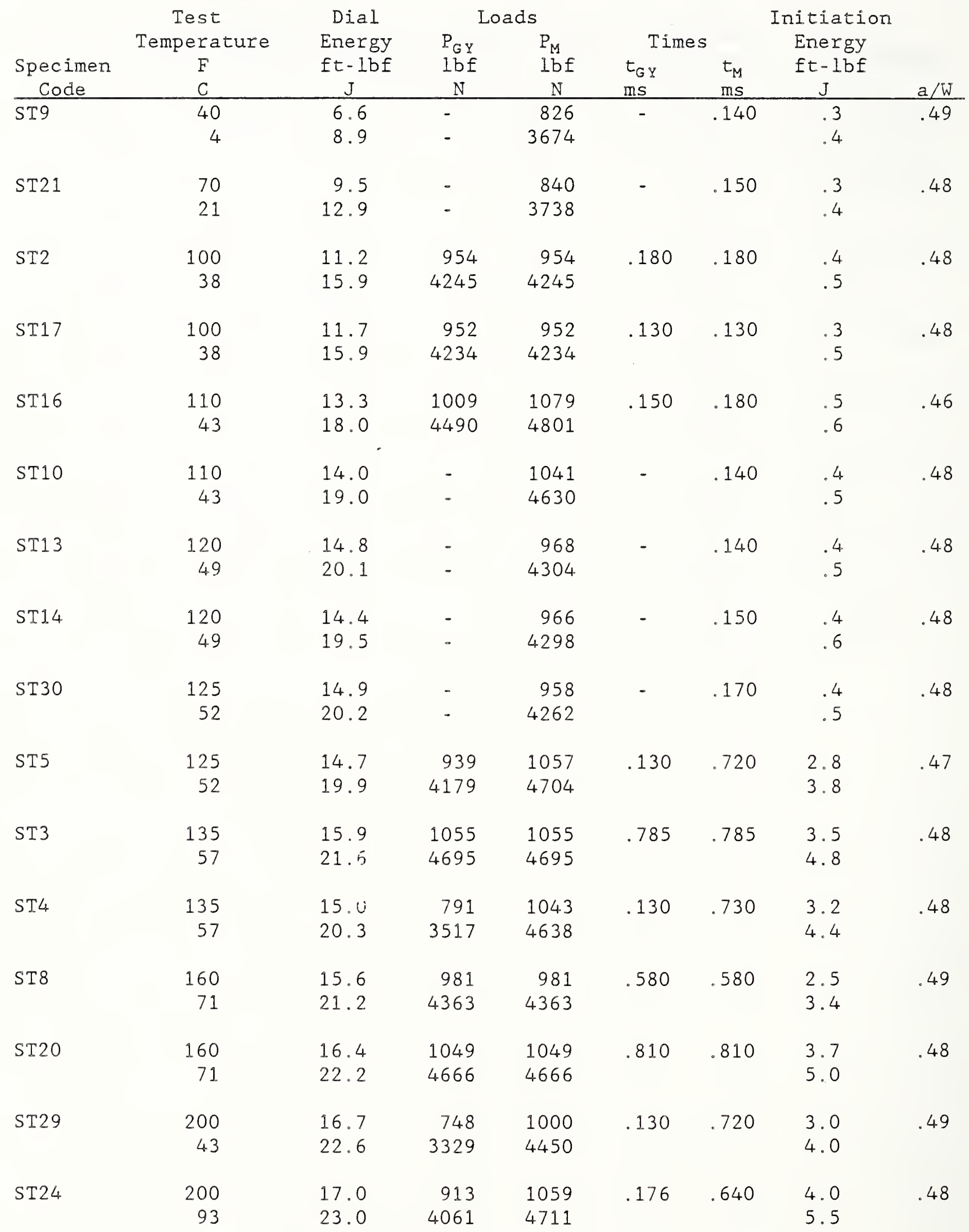


Table D17. Results of Instrumented Impact Evaluation of Precracked Charpy Specimens, Plate S, Orientation TL

\begin{tabular}{|c|c|c|c|c|c|c|c|c|}
\hline \multirow{2}{*}{$\begin{array}{l}\text { Specimen } \\
\text { Code }\end{array}$} & \multirow{2}{*}{$\begin{array}{l}\text { Test } \\
\text { Temp. } \\
\quad \text { F } \\
\text { C }\end{array}$} & \multirow[t]{2}{*}{$\begin{array}{l}\text { Dynamic } \\
\text { Yield } \\
\text { Stress } \\
\text { ksi } \\
\mathrm{MPa} \\
\end{array}$} & \multicolumn{3}{|c|}{$\begin{array}{c}\text { Normalized } \\
\text { Energies } \\
\text { in- } 1 \mathrm{~b} f / \mathrm{in}^{2} \\
\mathrm{KJ} / \mathrm{M}^{2}\end{array}$} & \multicolumn{2}{|c|}{$\begin{array}{l}\text { Fracture } \\
\text { Toughness } \\
\text { ksi/in } \\
\mathrm{MPa} / \mathrm{m}\end{array}$} & \multirow[t]{2}{*}{$\begin{array}{c}\text { Stress } \\
\text { Intensity } \\
\text { Rate } \\
\mathrm{ksi} / \mathrm{in} / \mathrm{s} \\
\mathrm{MPa} / \mathrm{m} / \mathrm{s}\end{array}$} \\
\hline & & & Total & Init. & Prop. & $\mathrm{K}_{\mathrm{ID}}$ & $\underline{K}_{\mathrm{JD}}$ & \\
\hline \multirow{2}{*}{ ST9 } & 40 & $>66.8$ & 995 & 18 & 977 & 34.0 & - & $0.24 E 6$ \\
\hline & 4 & $>460.6$ & 174 & 3 & 171 & 37.4 & - & $0.27 \mathrm{E} 6$ \\
\hline \multirow[t]{2}{*}{ ST21 } & 70 & $>66.0$ & 1411 & 18 & 1394 & 33.8 & - & $0.23 E 6$ \\
\hline & 21 & $>455.0$ & 247 & 3 & 244 & 37.2 & - & $0.25 \mathrm{E} 6$ \\
\hline \multirow[t]{2}{*}{ ST2 } & 100 & 75.7 & 1672 & 36 & 1636 & - & 46.4 & $0.26 E 6$ \\
\hline & 38 & 521.8 & 293 & 6 & 287 & - & 51.0 & $0.28 \mathrm{E} 6$ \\
\hline \multirow[t]{2}{*}{ ST17 } & 100 & 74.7 & 1738 & 21 & 1717 & - & 35.7 & $0.27 E 6$ \\
\hline & 38 & 515.3 & 304 & 4 & 301 & -. & 39.3 & $0.30 \mathrm{E} 6$ \\
\hline \multirow[t]{2}{*}{ ST16 } & 110 & 74.1 & 1911 & 37 & 1874 & - & 47.0 & $0.26 \mathrm{E} 6$ \\
\hline & 43 & 511.0 & 335 & 7 & 328 & - & 51.6 & $0.28 \mathrm{E} 6$ \\
\hline \multirow[t]{2}{*}{ ST10 } & 110 & $>80.9$ & 2070 & 27 & 2043 & 41.6 & - & $0.30 \mathrm{E} 6$ \\
\hline & 43 & $>558.0$ & 362 & 5 & 358 & 45.7 & - & $0.33 E 6$ \\
\hline \multirow[t]{2}{*}{ ST13 } & 120 & $>75.3$ & 2188 & 23 & 2165 & 38.6 & - & $0.28 E 6$ \\
\hline & 49 & $>518.9$ & 383 & 4 & 379 & 42.5 & - & $0.30 \mathrm{E} 6$ \\
\hline \multirow[t]{2}{*}{ ST14 } & 120 & $>76.6$ & 2150 & 24 & 2126 & 39.2 & - & $0.26 \mathrm{E} 6$ \\
\hline & 49 & $>528.3$ & 377 & 4 & 372 & 43.1 & - & $0.29 \mathrm{E} 6$ \\
\hline \multirow[t]{2}{*}{ ST30 } & 125 & $>76.0$ & 2225 & 24 & 2201 & 38.9 & - & $0.23 \mathrm{E} 6$ \\
\hline & 52 & $>523.9$ & 390 & 4 & 385 & 42.7 & - & $0.25 \mathrm{E} 6$ \\
\hline \multirow[t]{2}{*}{ ST5 } & 125 & 72.3 & 2163 & 387 & 1776 & - & 151.4 & $0.21 \mathrm{E} 6$ \\
\hline & 52 & 498.8 & 379 & 68 & 311 & - & 166.3 & $0.23 E 6$ \\
\hline \multirow[t]{2}{*}{ ST3 } & 135 & 81.3 & 2339 & 482 & 1857 & - & 168.9 & $0.21 \mathrm{E} 6$ \\
\hline & 57 & 560.4 & 410 & 84 & 325 & - & 185.6 & $0.24 E 6$ \\
\hline \multirow[t]{2}{*}{ ST4 } & 135 & 62.1 & 2229 & 439 & 1789 & - & 161.2 & $0.22 \mathrm{E} 6$ \\
\hline & 57 & 428.0 & 390 & 77 & 313 & - & 177.2 & $0.24 \mathrm{E} 6$ \\
\hline \multirow[t]{2}{*}{ ST8 } & 160 & 79.3 & 2352 & 338 & 2014 & - & 141.1 & $0.24 \mathrm{E} 6$ \\
\hline & 71 & 546.9 & 412 & 59 & 353 & - & 155.0 & $0.27 \mathrm{E} 6$ \\
\hline \multirow[t]{2}{*}{ ST20 } & 160 & 83.2 & 2448 & 514 & 1935 & - & 174.0 & $0.21 E 6$ \\
\hline & 71 & 573.5 & 429 & 90 & 339 & - & 191.2 & $0.24 E 6$ \\
\hline \multirow[t]{2}{*}{ ST29 } & 200 & 61.1 & 2530 & 410 & 2120 & - & 155.0 & $0.21 \mathrm{E} 6$ \\
\hline & 93 & 421.5 & 443 & 72 & 371 & - & 170.3 & $0.24 \mathrm{E} 6$ \\
\hline \multirow[t]{2}{*}{ ST24 } & $\begin{array}{r}200 \\
93\end{array}$ & 71.7 & 2526 & 503 & 2022 & - & 171.7 & $0.27 E 6$ \\
\hline & 93 & 494.3 & 442 & 88 & 354 & - & 188.6 & $0.29 \mathrm{E} 6$ \\
\hline
\end{tabular}


Table D18. Young's Modulus and Compliance Values for Plate S, Orientation TL

\begin{tabular}{|c|c|c|c|c|c|}
\hline Specimen & $\begin{array}{l}\text { Temp } \\
\text { F } \\
\text { C }\end{array}$ & $\begin{array}{c}\text { YM } \\
k s i \times 10^{3} \\
\operatorname{MPa} \times 10^{3}\end{array}$ & $\begin{array}{c}\mathrm{C}_{\mathrm{T}} \\
\mathrm{in-lbf^{-1 }} \times \mathrm{mN}^{-1} \times 10^{-6} \\
\mathrm{mN}^{-8}\end{array}$ & $\begin{array}{c}\mathrm{C}_{S} \\
\text { in- } 1 \mathrm{bf} f^{-1} \times 10^{-6} \\
\mathrm{mN}^{-1} \times 10^{-8}\end{array}$ & $\begin{array}{c}C_{M} \\
\text { in- } 1 b f^{-1} \times 10^{-6} \\
m N^{-1} \times 10^{-8}\end{array}$ \\
\hline ST9 & $\begin{array}{r}40 \\
4\end{array}$ & $\begin{array}{r}33 \\
228\end{array}$ & $\begin{array}{r}11.0 \\
6.3\end{array}$ & $\begin{array}{l}4.2 \\
2.4\end{array}$ & $\begin{array}{l}6.9 \\
3.9\end{array}$ \\
\hline ST21 & $\begin{array}{l}70 \\
21\end{array}$ & $\begin{array}{r}33 \\
228\end{array}$ & $\begin{array}{l}9.0 \\
5.1\end{array}$ & $\begin{array}{l}4.1 \\
2.3\end{array}$ & $\begin{array}{l}5.0 \\
2.9\end{array}$ \\
\hline ST2 & $\begin{array}{r}100 \\
38\end{array}$ & $\begin{array}{r}30 \\
207\end{array}$ & $\begin{array}{l}9.9 \\
5.6\end{array}$ & $\begin{array}{l}4.5 \\
2.6\end{array}$ & $\begin{array}{l}5.4 \\
3.1\end{array}$ \\
\hline ST17 & $\begin{array}{r}100 \\
38\end{array}$ & $\begin{array}{r}30 \\
207\end{array}$ & $\begin{array}{l}9.9 \\
5.6\end{array}$ & $\begin{array}{l}4.5 \\
2.6\end{array}$ & $\begin{array}{l}5.4 \\
3.1\end{array}$ \\
\hline ST16 & $\begin{array}{r}110 \\
43\end{array}$ & $\begin{array}{r}30 \\
207\end{array}$ & $\begin{array}{l}8.3 \\
4.7\end{array}$ & $\begin{array}{l}4.2 \\
2.4\end{array}$ & $\begin{array}{l}4.1 \\
2.3\end{array}$ \\
\hline ST10 & $\begin{array}{r}110 \\
43\end{array}$ & $\begin{array}{r}33 \\
228\end{array}$ & $\begin{array}{l}8.8 \\
5.0\end{array}$ & $\begin{array}{l}4.0 \\
2.3\end{array}$ & $\begin{array}{l}4.7 \\
2.7\end{array}$ \\
\hline ST13 & $\begin{array}{r}120 \\
49\end{array}$ & $\begin{array}{r}33 \\
228\end{array}$ & $\begin{array}{l}9.4 \\
5.4\end{array}$ & $\begin{array}{l}4.1 \\
2.3\end{array}$ & $\begin{array}{l}5.4 \\
3.1\end{array}$ \\
\hline ST14 & $\begin{array}{r}120 \\
49\end{array}$ & $\begin{array}{r}33 \\
228\end{array}$ & $\begin{array}{r}10.0 \\
5.7\end{array}$ & $\begin{array}{l}4.1 \\
2.3\end{array}$ & $\begin{array}{l}6.0 \\
3.4\end{array}$ \\
\hline $\mathrm{ST} 30$ & $\begin{array}{r}125 \\
52\end{array}$ & $\begin{array}{r}23 \\
228\end{array}$ & $\begin{array}{l}9.9 \\
5.6\end{array}$ & $\begin{array}{l}4.1 \\
2.3\end{array}$ & $\begin{array}{l}5.7 \\
3.2\end{array}$ \\
\hline ST5 & $\begin{array}{r}125 \\
52\end{array}$ & $\begin{array}{r}30 \\
207\end{array}$ & $\begin{array}{l}7.7 \\
4.4\end{array}$ & $\begin{array}{l}4.4 \\
2.5\end{array}$ & $\begin{array}{l}3.3 \\
1.9\end{array}$ \\
\hline ST 3 & $\begin{array}{r}135 \\
57\end{array}$ & $\begin{array}{r}30 \\
207\end{array}$ & $\begin{array}{r}10.0 \\
5.7\end{array}$ & $\begin{array}{l}4.4 \\
2.5\end{array}$ & $\begin{array}{l}5.6 \\
3.2\end{array}$ \\
\hline ST4 & $\begin{array}{r}135 \\
57\end{array}$ & $\begin{array}{r}30 \\
207\end{array}$ & $\begin{array}{r}11.0 \\
6.3\end{array}$ & $\begin{array}{l}4.5 \\
2.5\end{array}$ & $\begin{array}{l}6.2 \\
3.2\end{array}$ \\
\hline ST8 & $\begin{array}{r}160 \\
71\end{array}$ & $\begin{array}{r}29 \\
200\end{array}$ & $\begin{array}{r}10.0 \\
5.7\end{array}$ & $\begin{array}{l}4.7 \\
2.7\end{array}$ & $\begin{array}{l}5.8 \\
3.3\end{array}$ \\
\hline ST20 & $\begin{array}{r}160 \\
71\end{array}$ & $\begin{array}{r}29 \\
200\end{array}$ & $\begin{array}{r}10.0 \\
5.7\end{array}$ & $\begin{array}{l}4.6 \\
2.6\end{array}$ & $\begin{array}{l}5.8 \\
3.3\end{array}$ \\
\hline ST29 & $\begin{array}{r}200 \\
93\end{array}$ & $\begin{array}{r}29 \\
200\end{array}$ & $\begin{array}{r}11.0 \\
6.3\end{array}$ & $\begin{array}{l}4.7 \\
2.7\end{array}$ & $\begin{array}{l}6.6 \\
3.8\end{array}$ \\
\hline $\mathrm{ST} 24$ & $\begin{array}{r}200 \\
93\end{array}$ & $\begin{array}{r}29 \\
200\end{array}$ & $\begin{array}{l}18.0 \\
10.0\end{array}$ & $\begin{array}{l}4.6 \\
2.6\end{array}$ & $\begin{array}{r}14.0 \\
8.0\end{array}$ \\
\hline
\end{tabular}




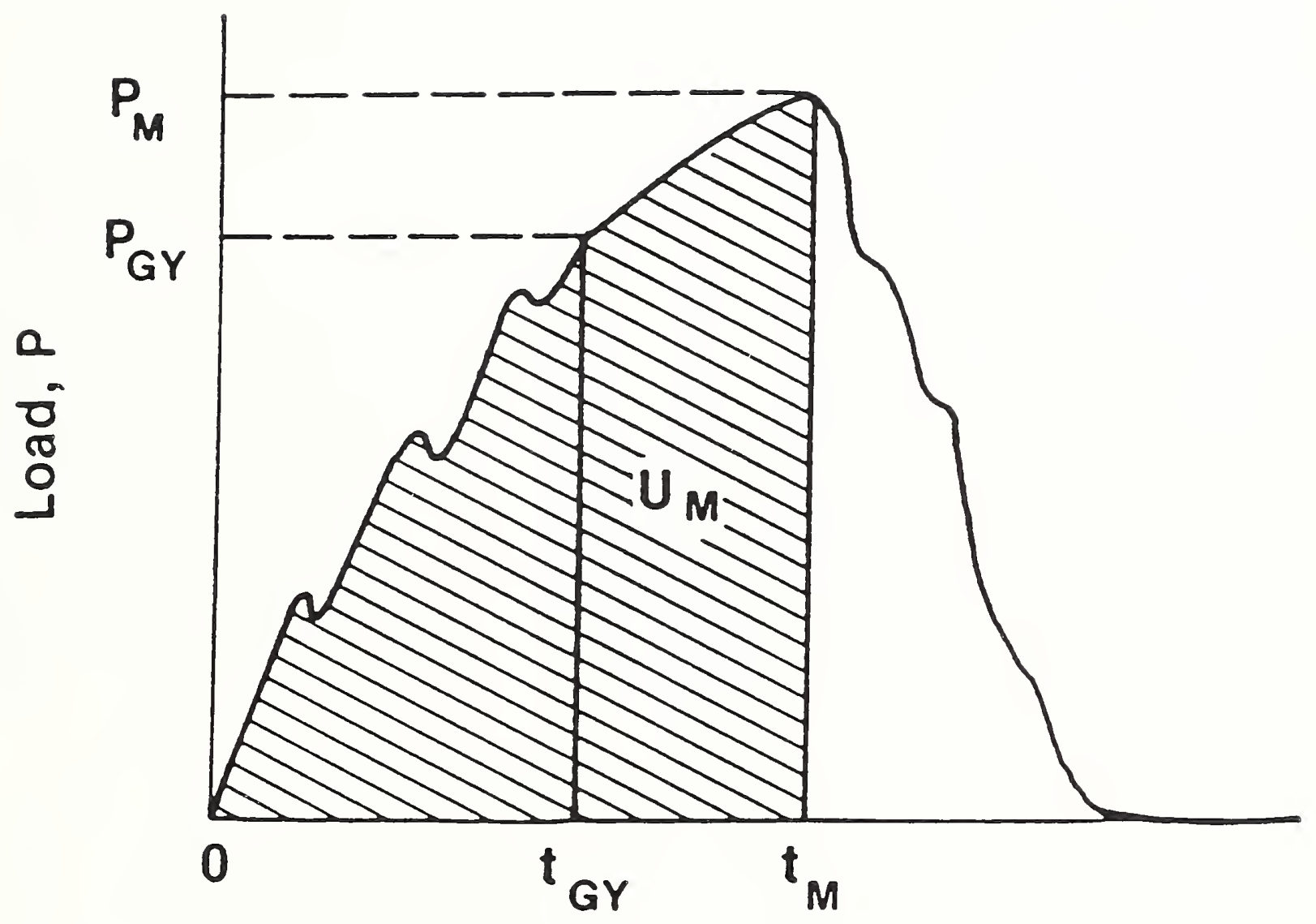

Time, $t$

Figure, 1. Idealized Load-Time Record for a Three Point Bend Specimen. 


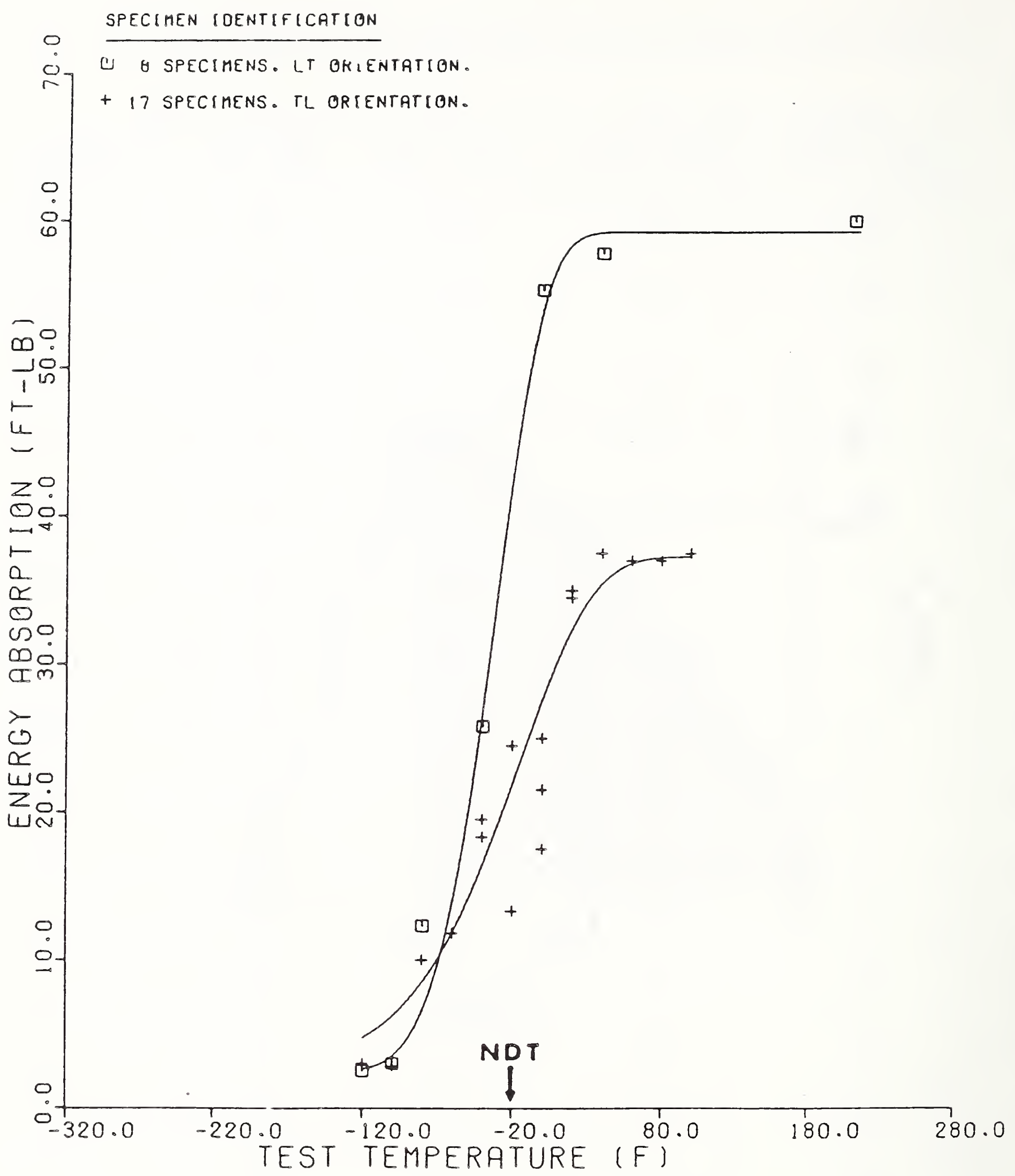

Figure 2. Charpy V-notch-Energy Absorption Results for Plate $G$. 


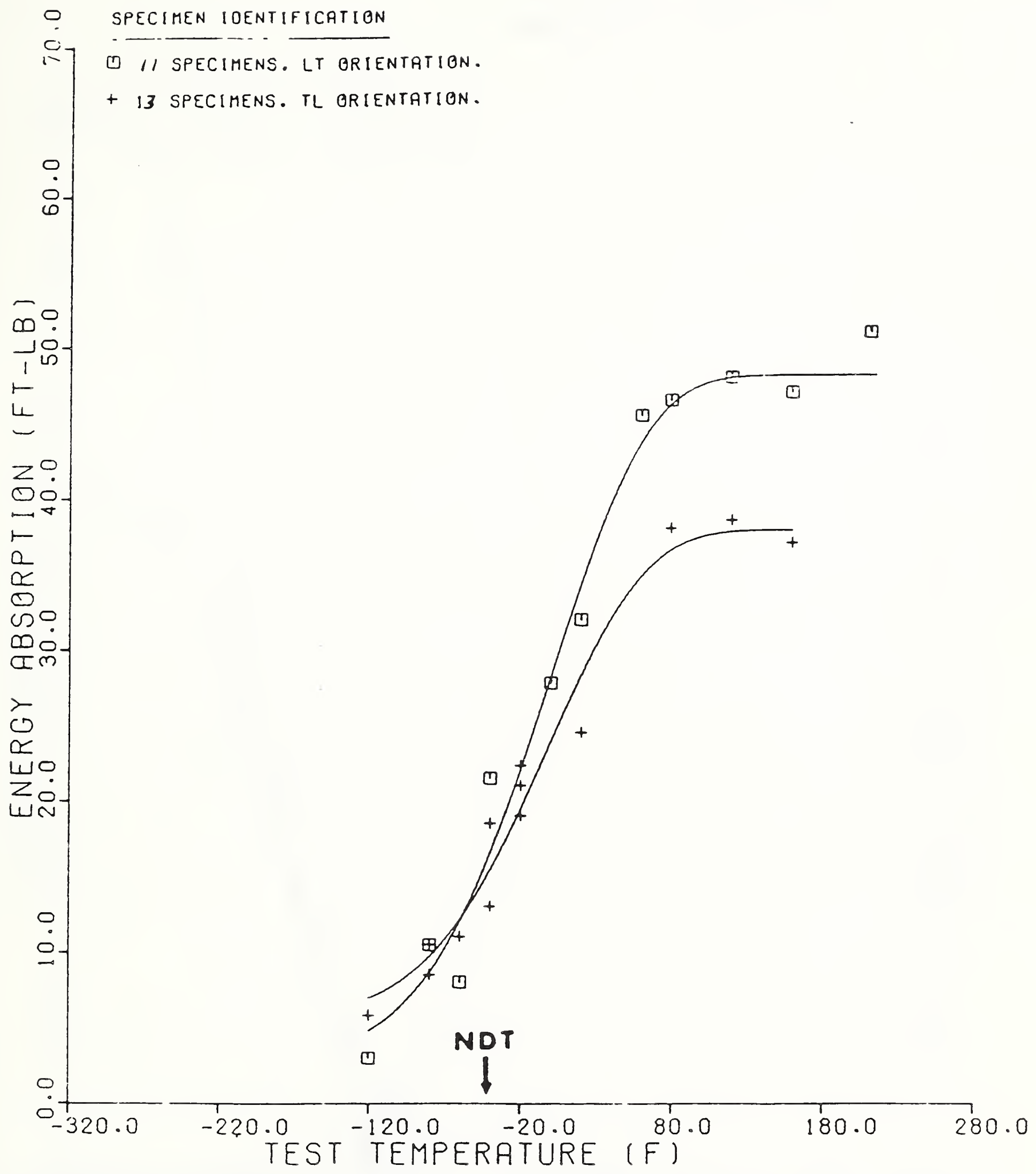

Eigure 3. Charpy V-notch-Energy Absorption Results for Plate U. 


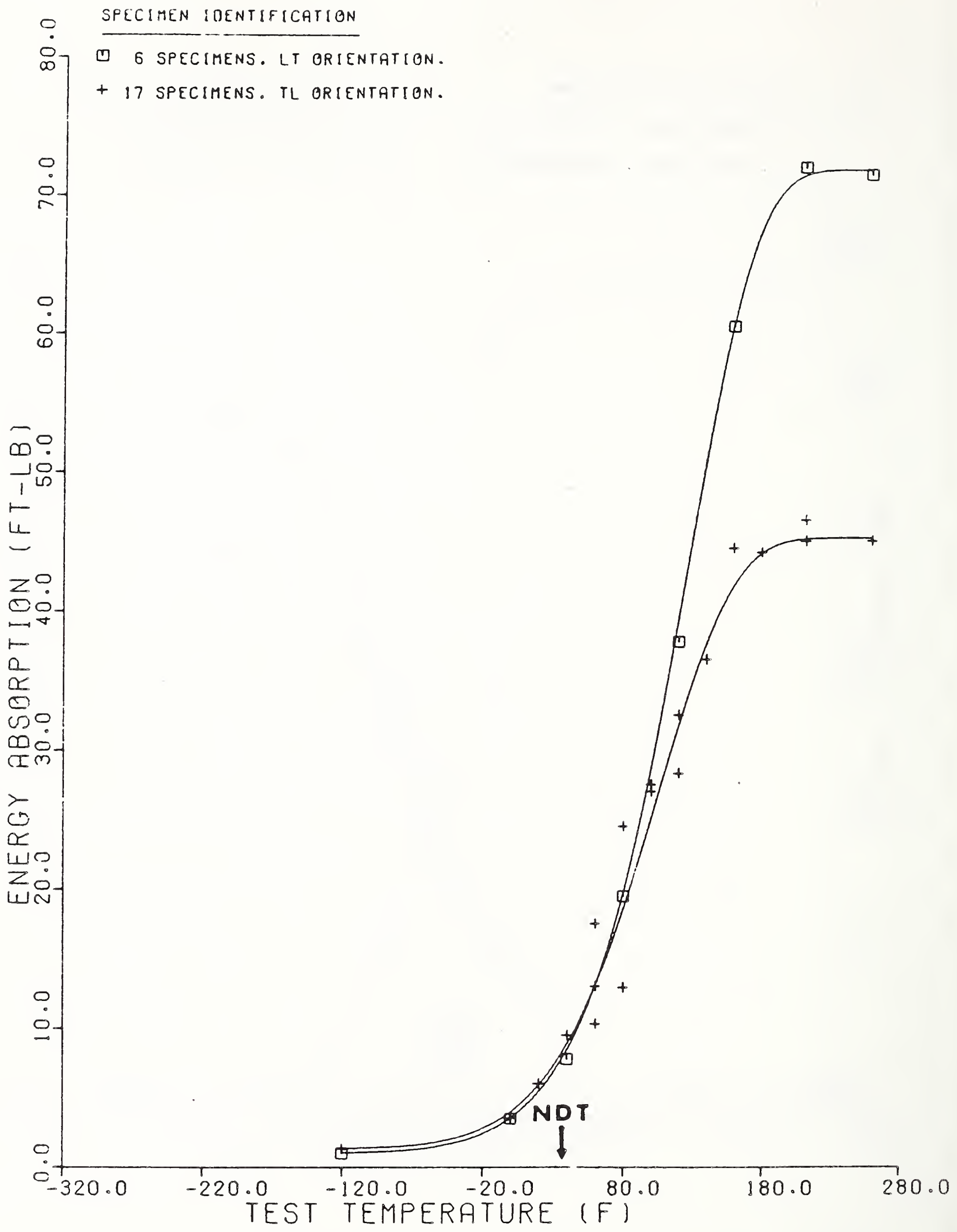

Figure 4. Charpy V-notch-Energy Absorption Results for Plate S. 


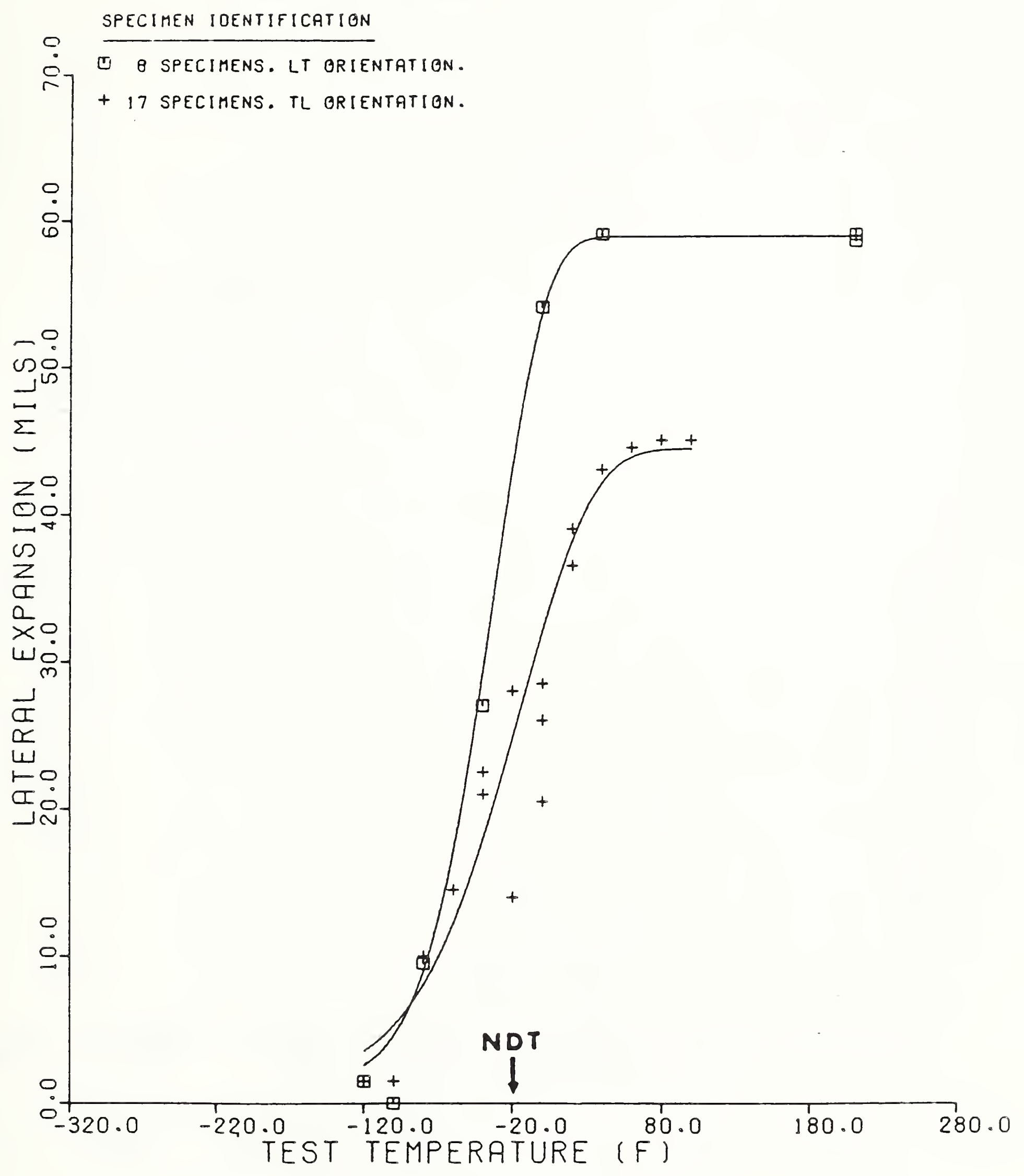

Figure 5. Charpy V-notch-Lateral Expansion Results for Plate G. 


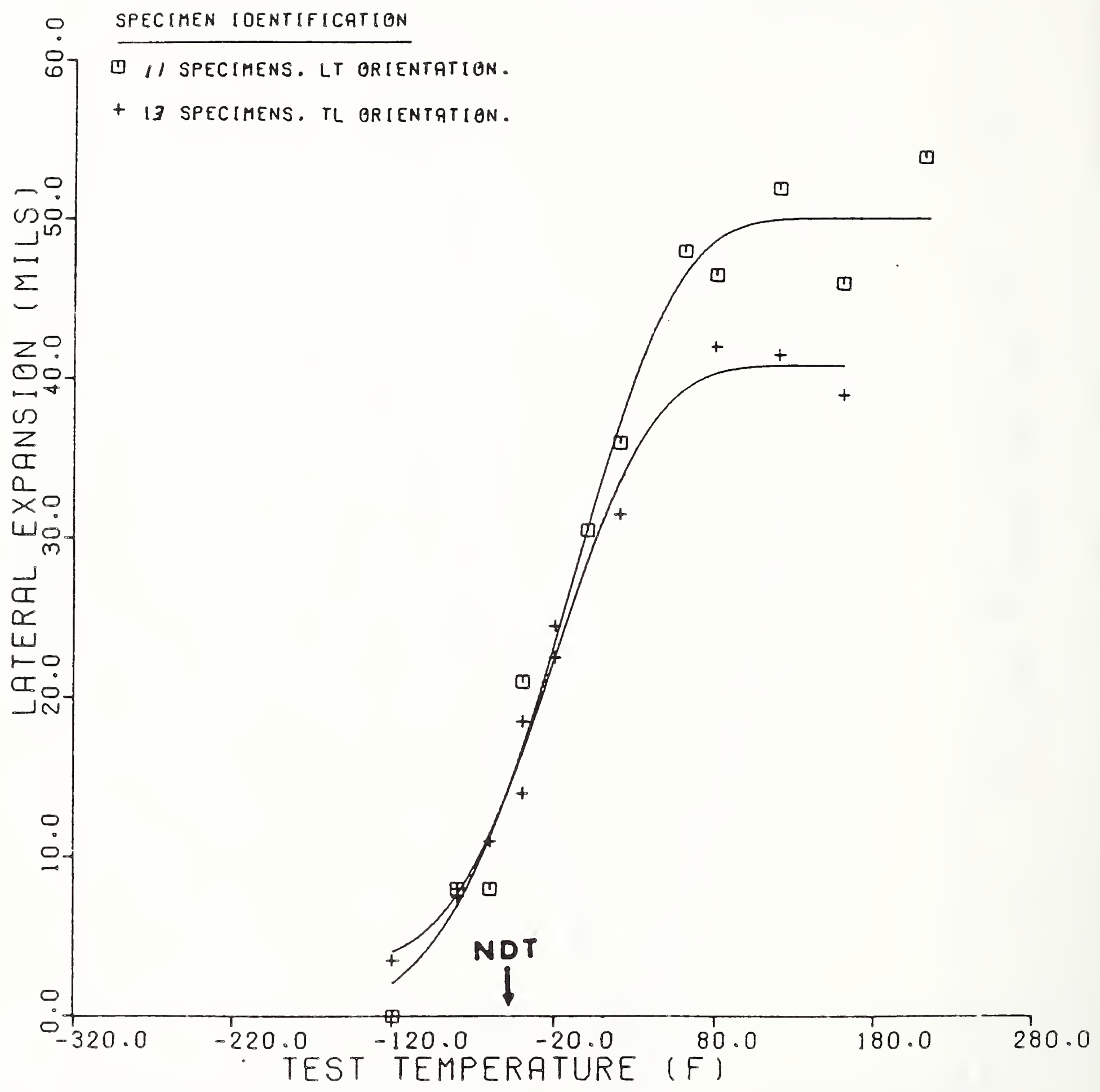

Figure 6. Charpy V-notch-Lateral Expansion Results for Plate U. 


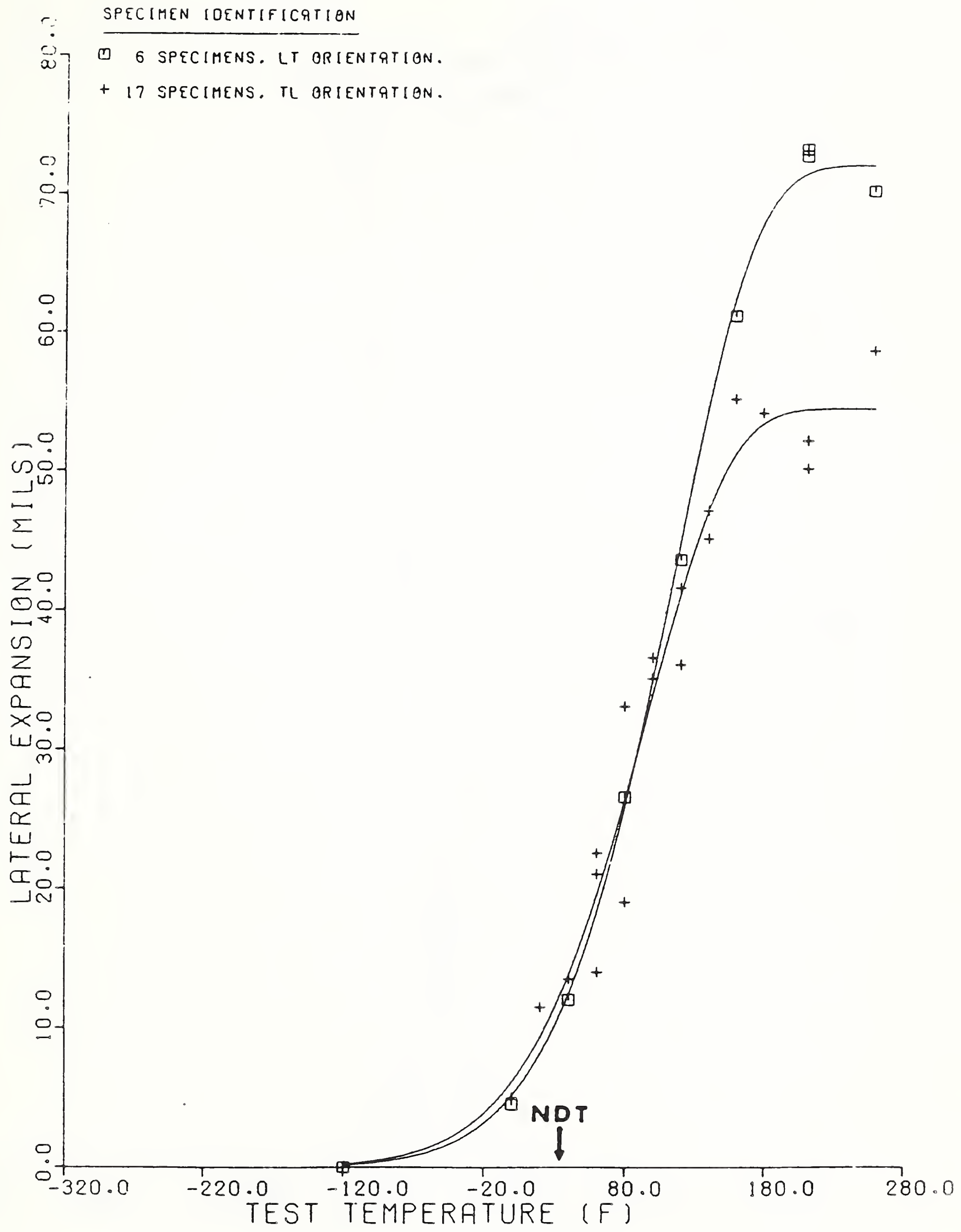

Figure 7. Charpy V-notch-Lateral Expansion Results for Plate S. 


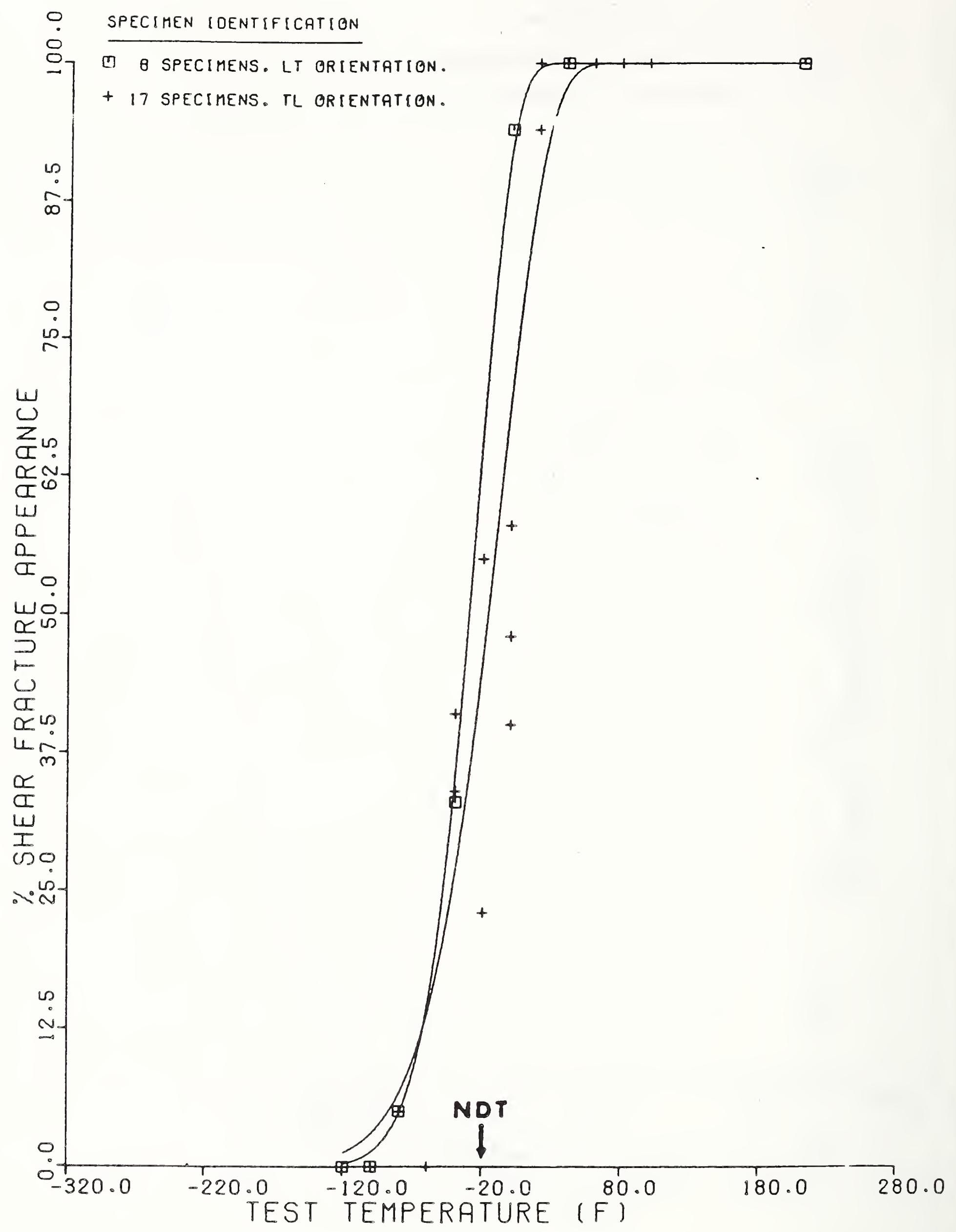

Figure 8. Charpy V-notch-Shear Fracture Appearance Results for Plate G. 
- SPECIMEN IDENTIFICATION

○. $\square$ II SPECIMENS. LT ORIENTGTION.

+13 SPECIMENS. Tl orientgTion.

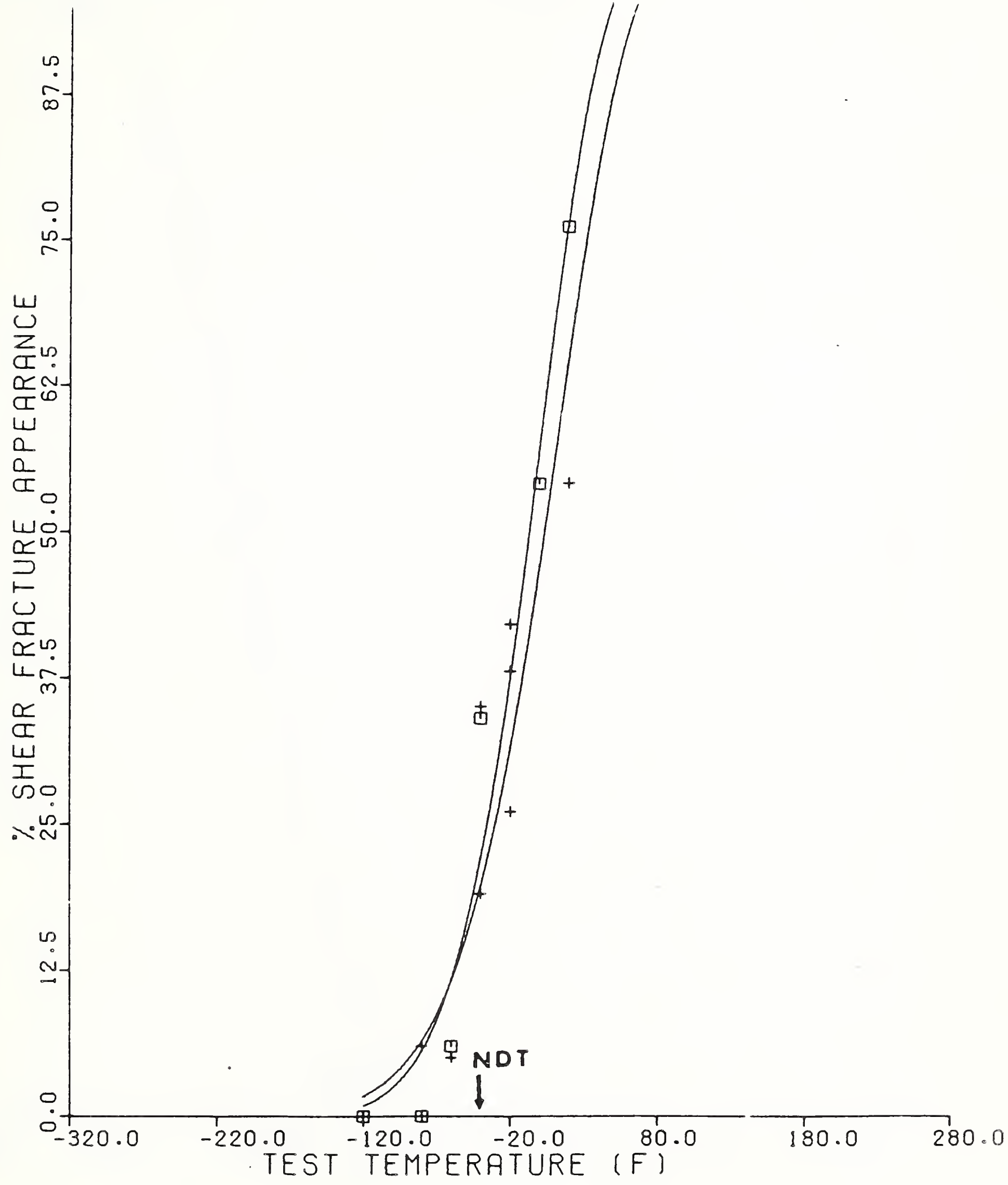

Figure 9. Charpy V-notch-Shear Fracture Appearance Results for Plate U. 


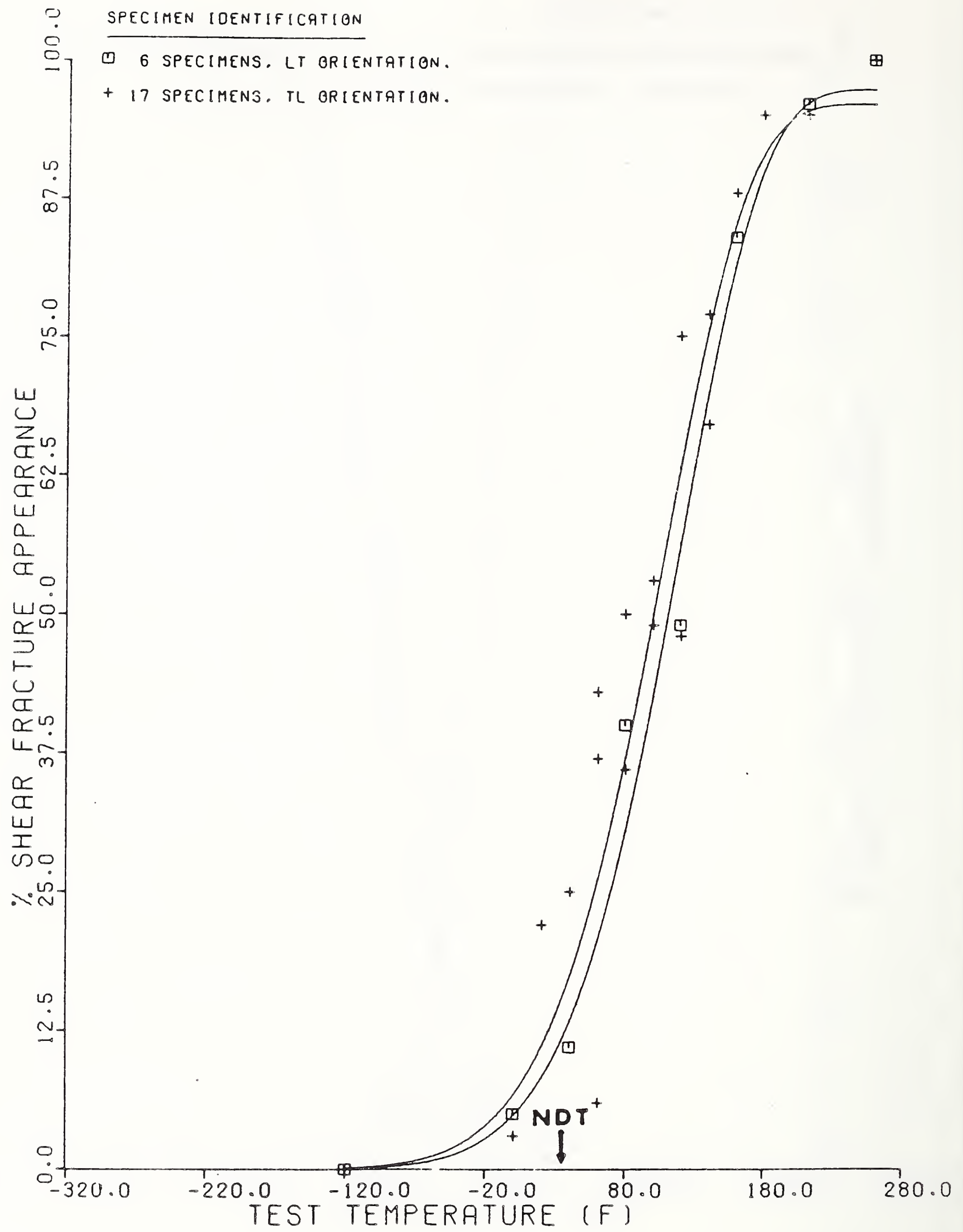

Figure 10. Charpy V-notch-Shear Fracture Appearance Results for Plate S. 


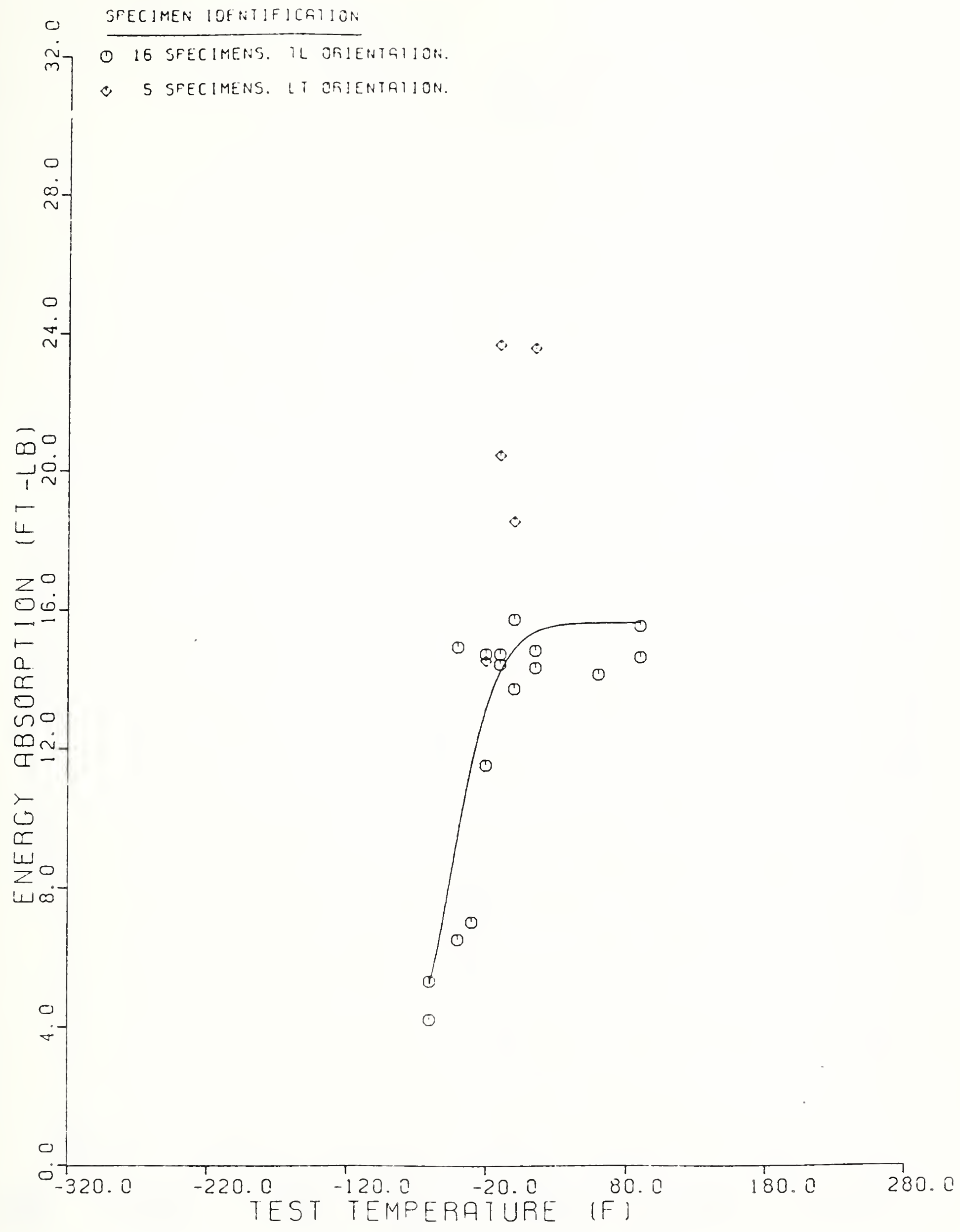

Figure 11. Precracked Charpy-Total Energy Absorption Results for Plate G. 


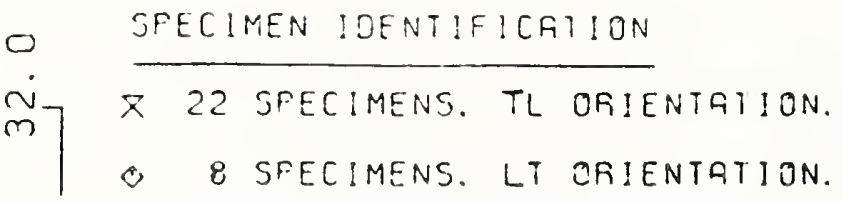

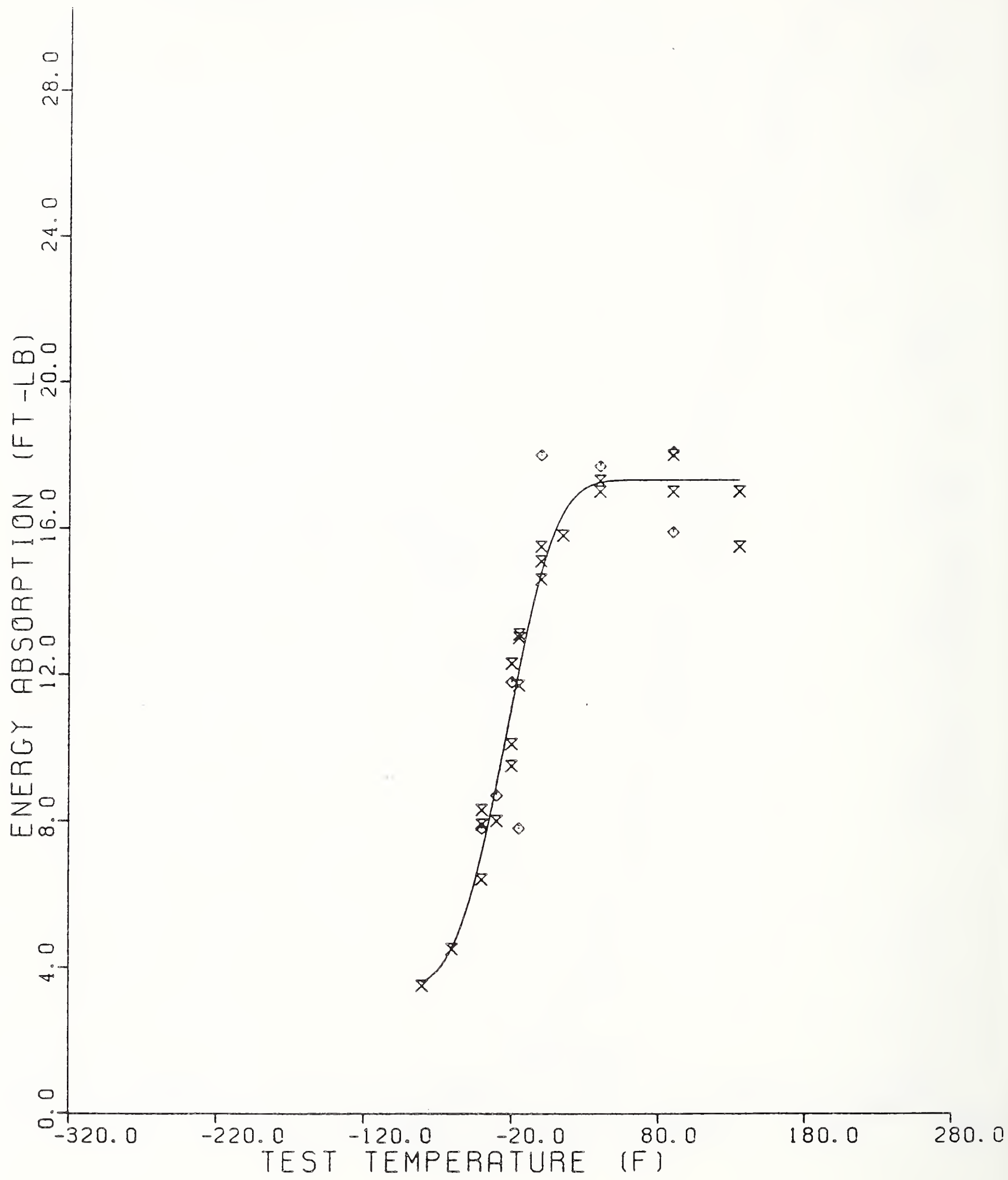

Figure 12. Precracked Charpy-Total Energy Absorption Results for Plate U. 


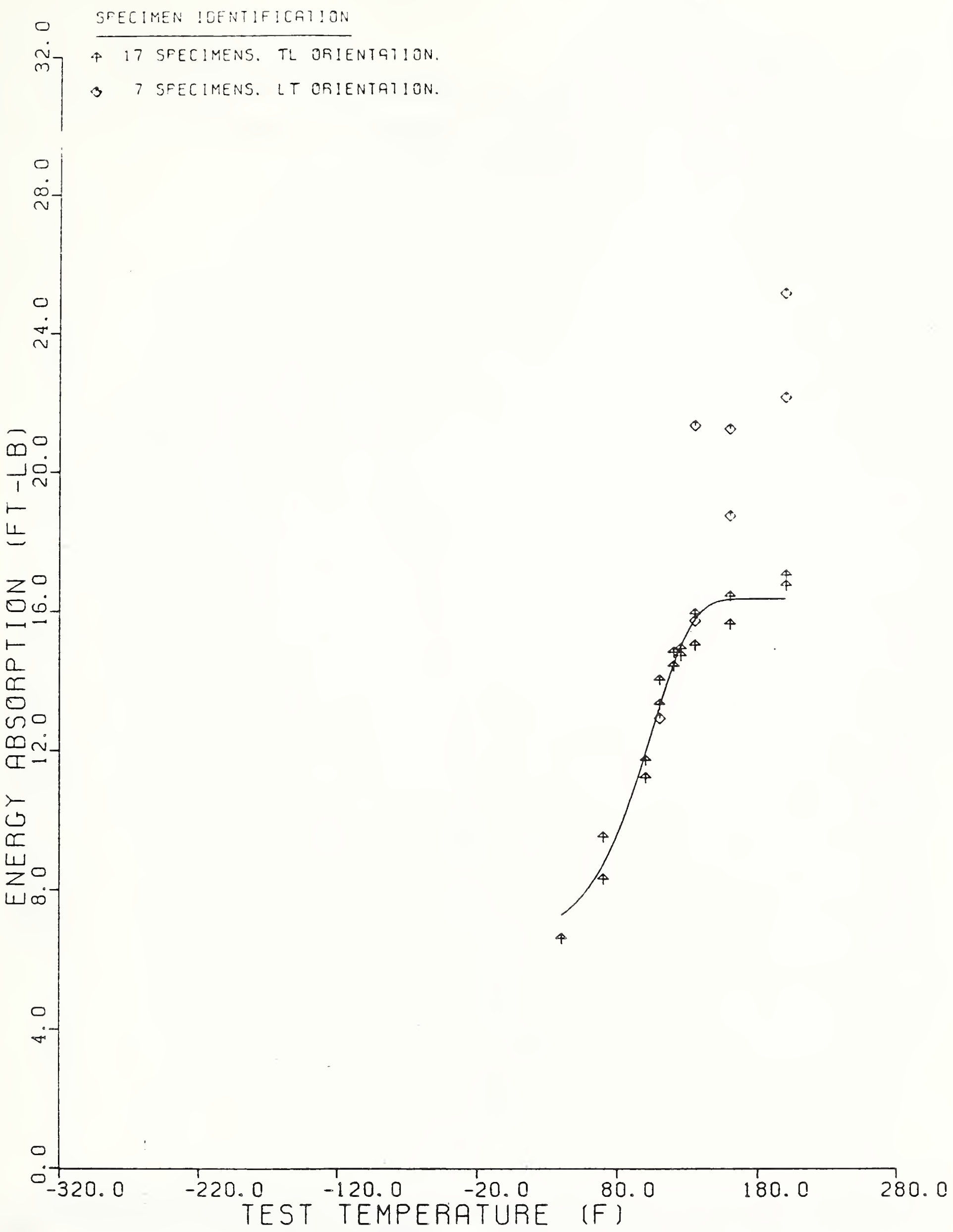

Figure 13. Precracked Charpy-Total Energy Absorption Results for Plate S. 


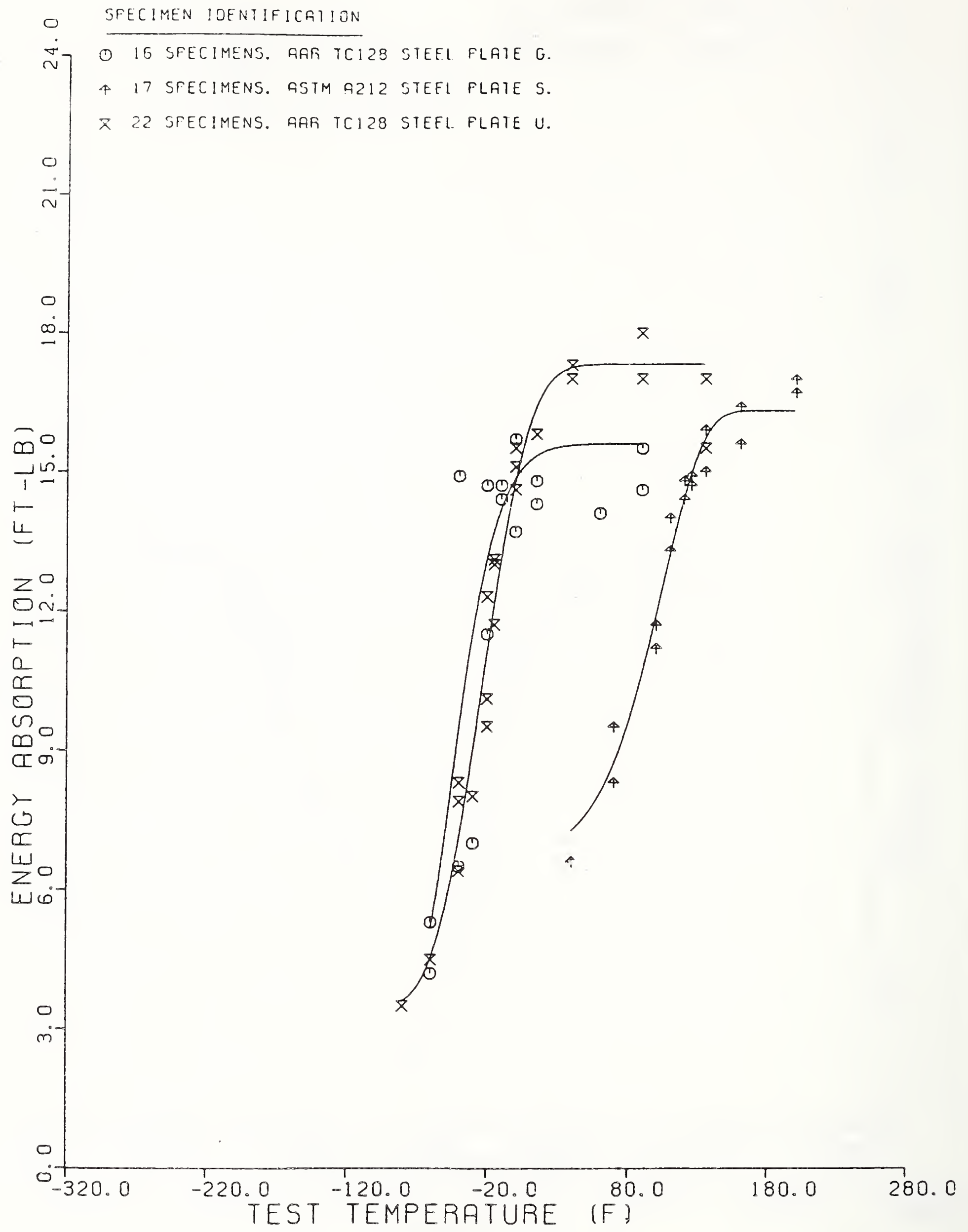

Figure 14. Comparison of Total Energy Absorbed for Plates G, U, and S. 


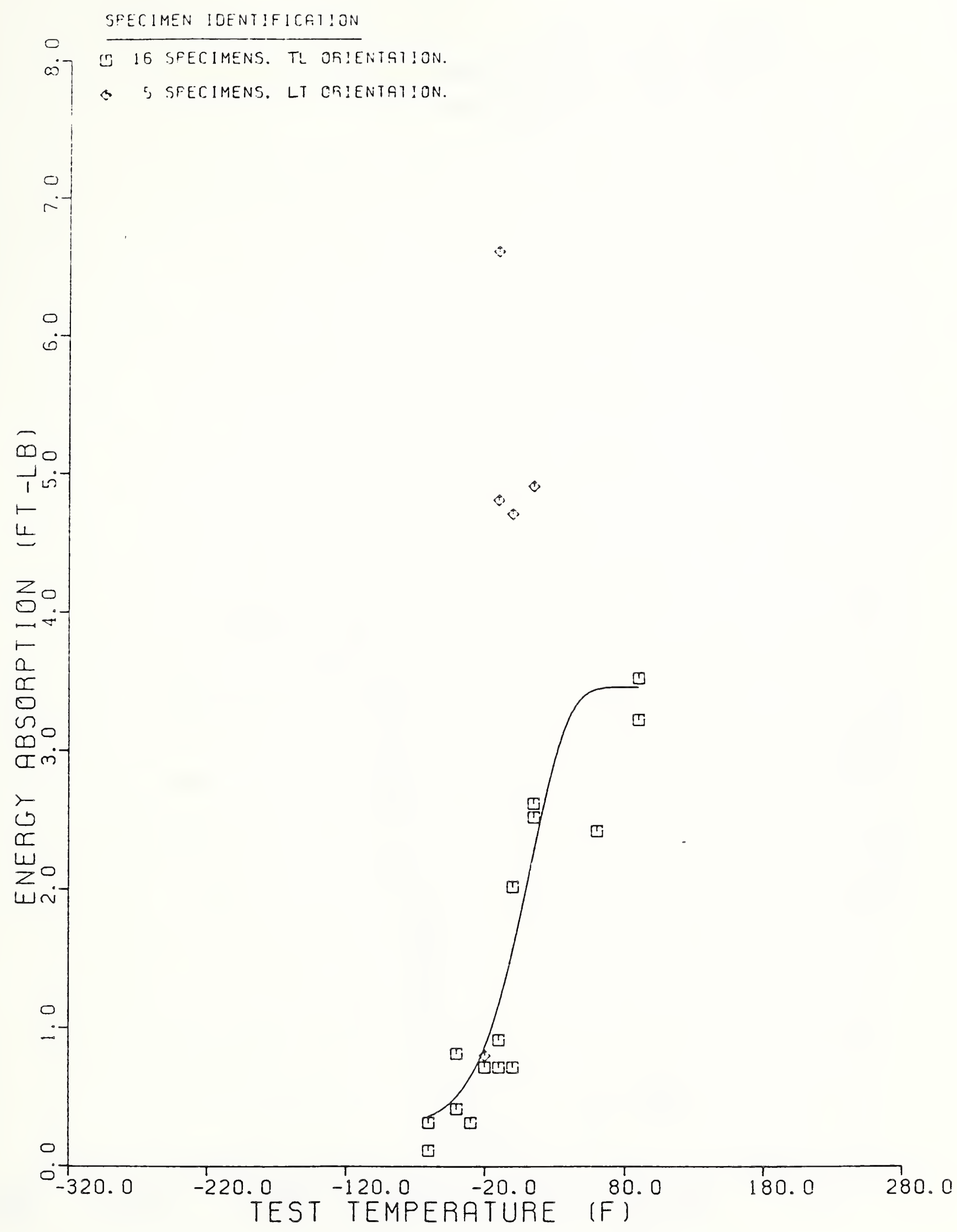

Figure 15. Precracked Charpy-Energy Absorbed to Maximum Load for Plate G. 


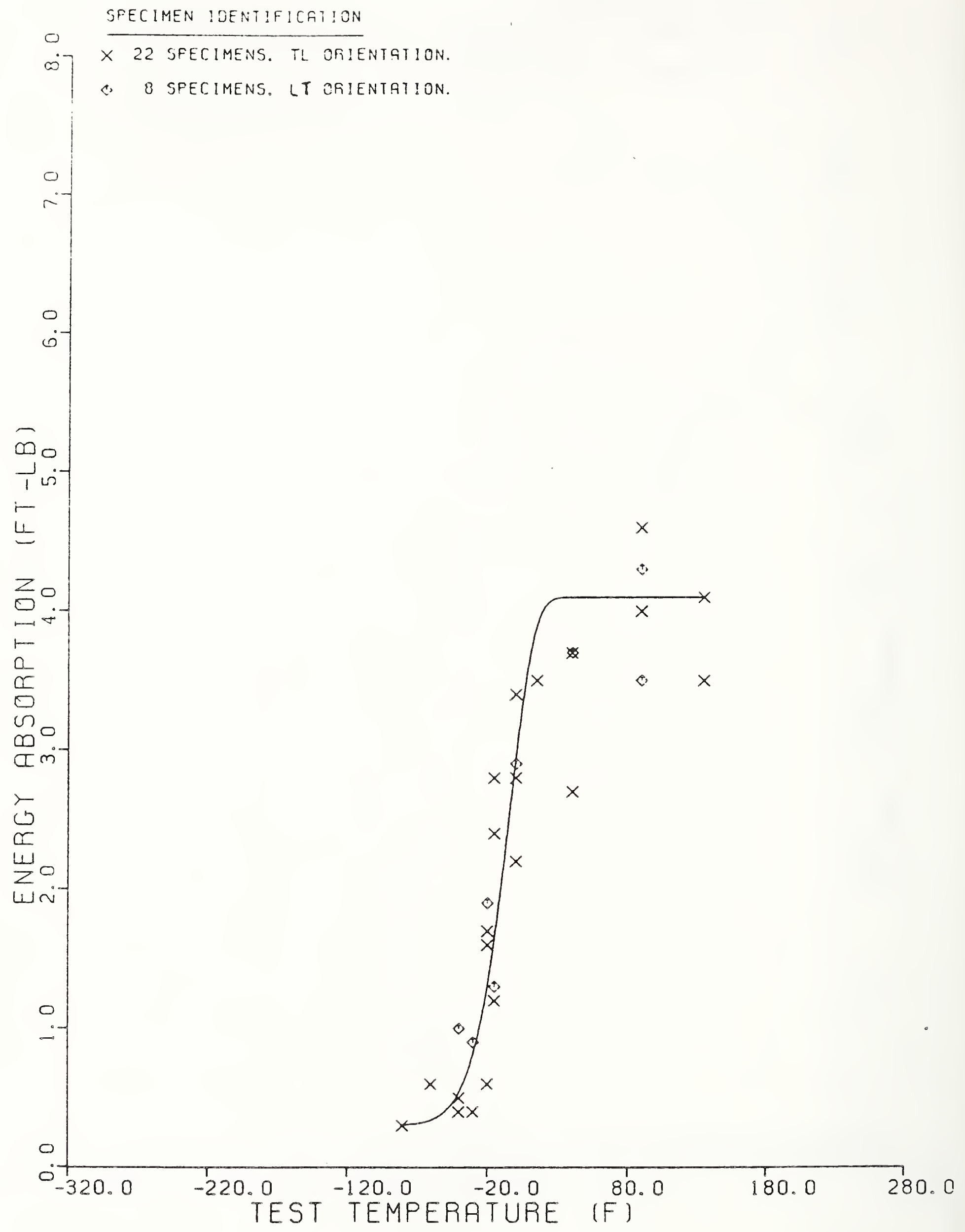

Figure 16. Precracked Charpy-Energy Absorbed to Maximum Load for Plate U. 


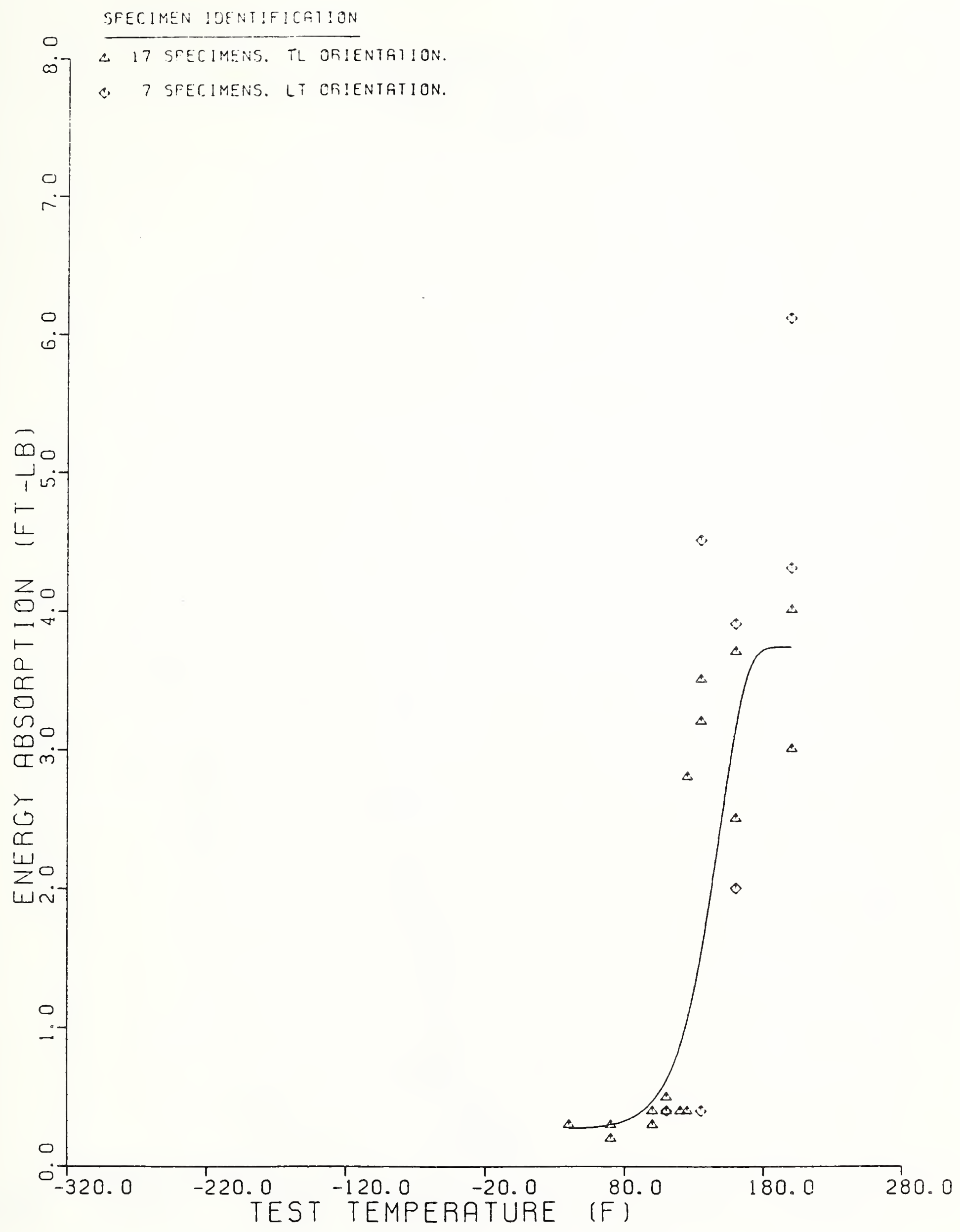

Figure 17. Precracked Charpy-Energy Absorbed to Maximum Load for Plate S. 


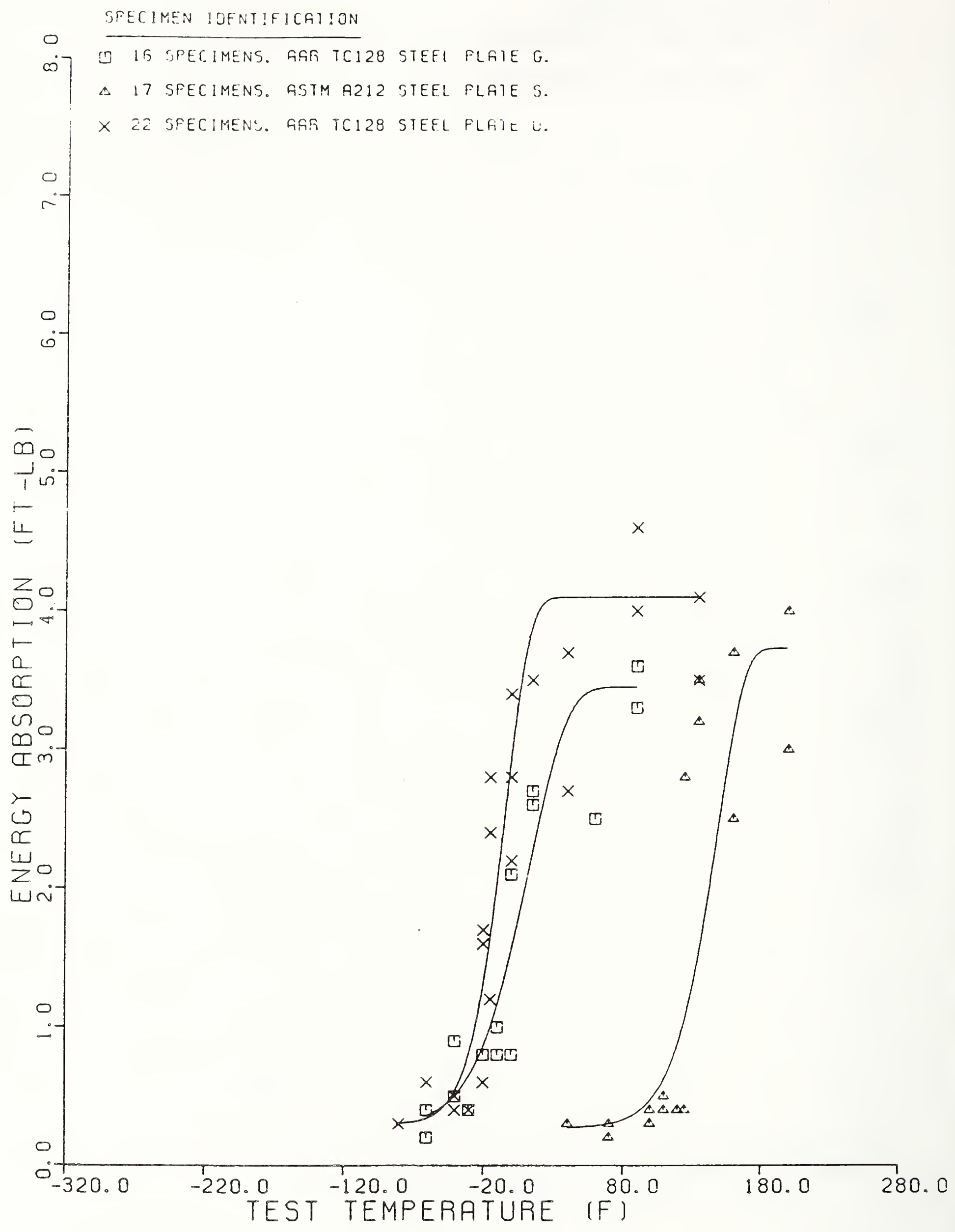

Figure 18. Comparison of Energy Absorbed to Maximum Load for Plates G, U, and $S$. 


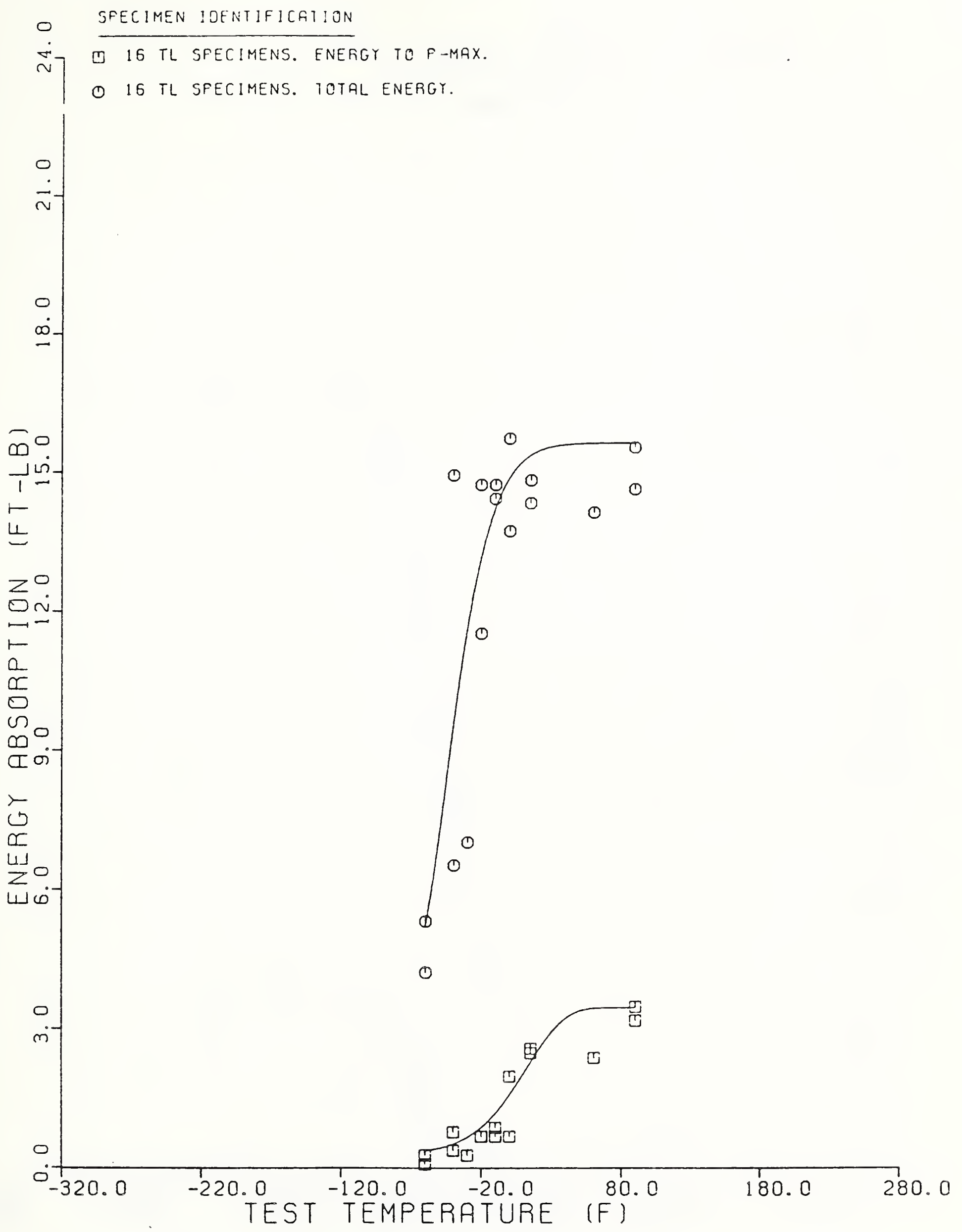

Figure 19. Comparison of Total Energy and Energy Absorbed to Maximum Load for Plate $G$. 


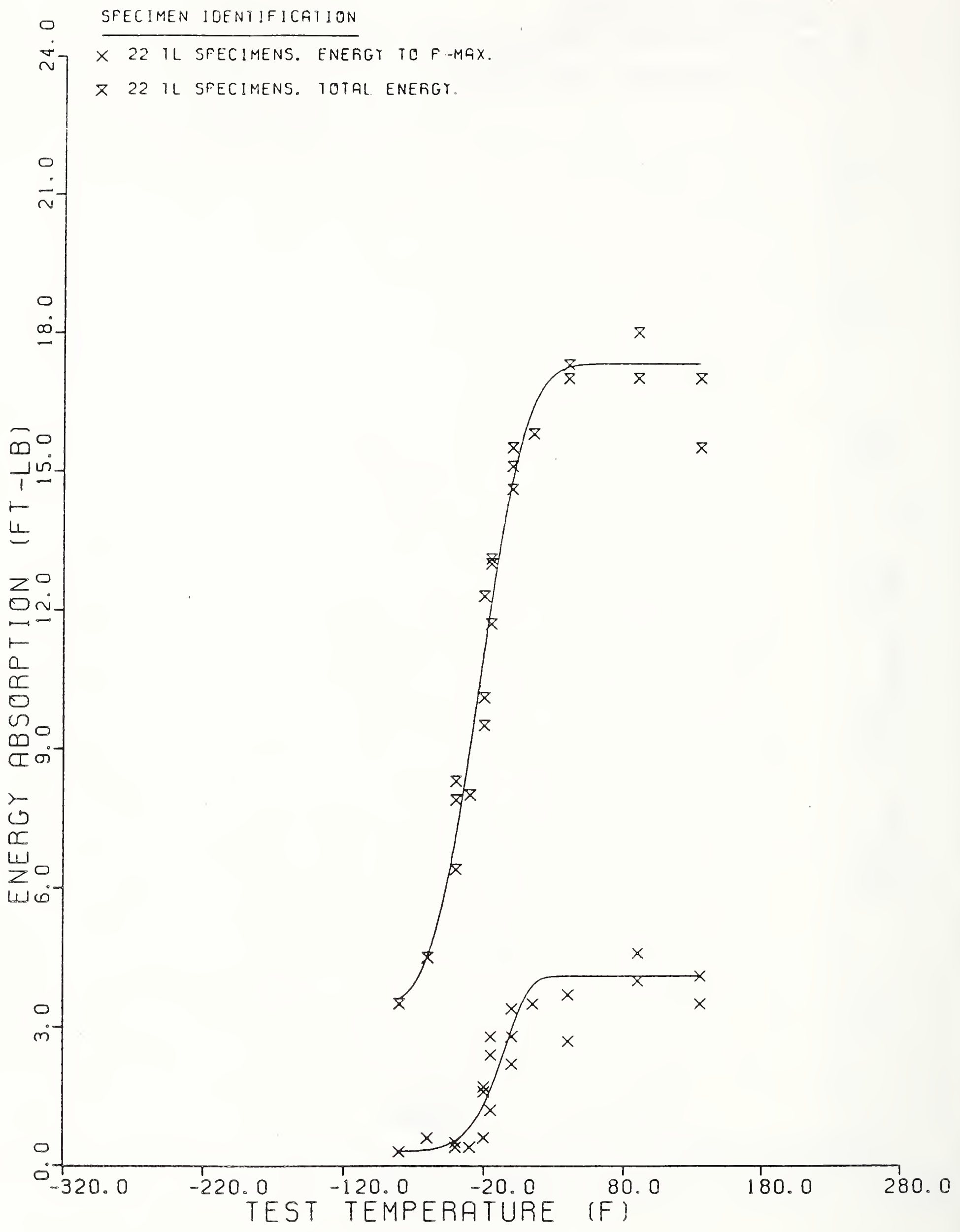

Figure 20. Comparison of Toral Energy and Energy Absorbed to Maximum Load for Plate U. 


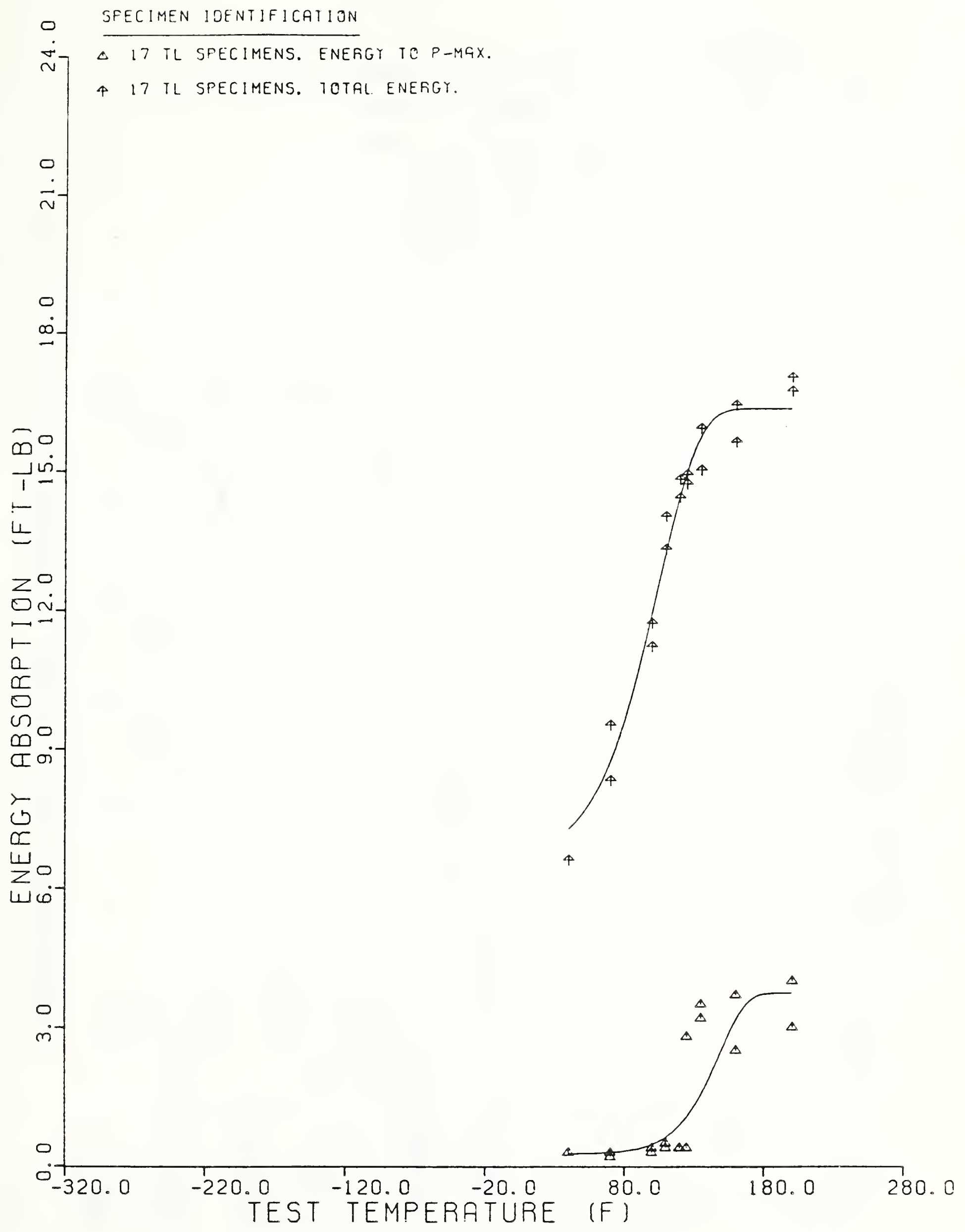

Figure 21. Comparison of Total Energy and Energy Absorbed to Maximum Load for Plate $S$. 


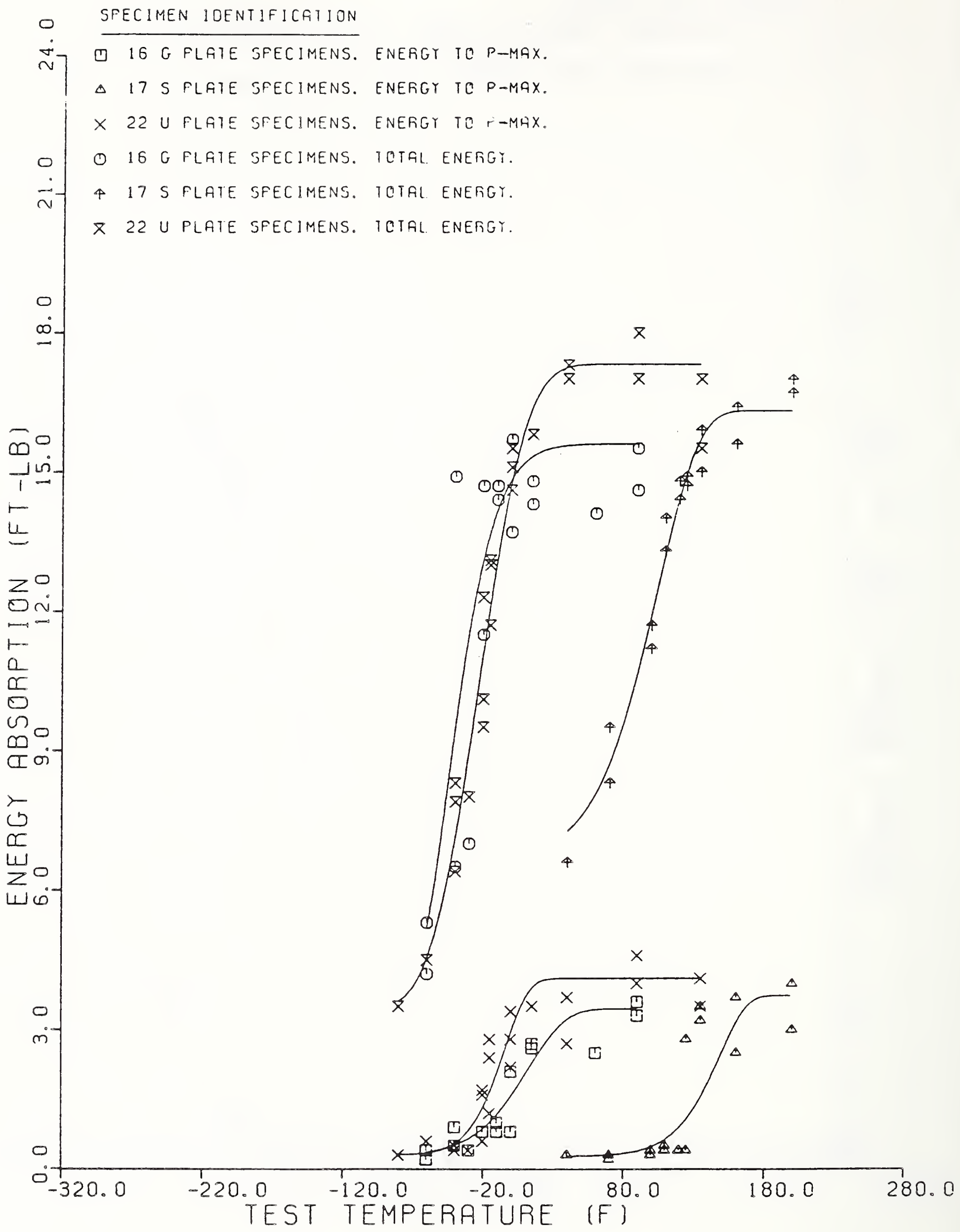

Figure 22. Comparison of Total Energy and Energy Absorbed to Maximum Load for Plates $G, U$, and $S$. 


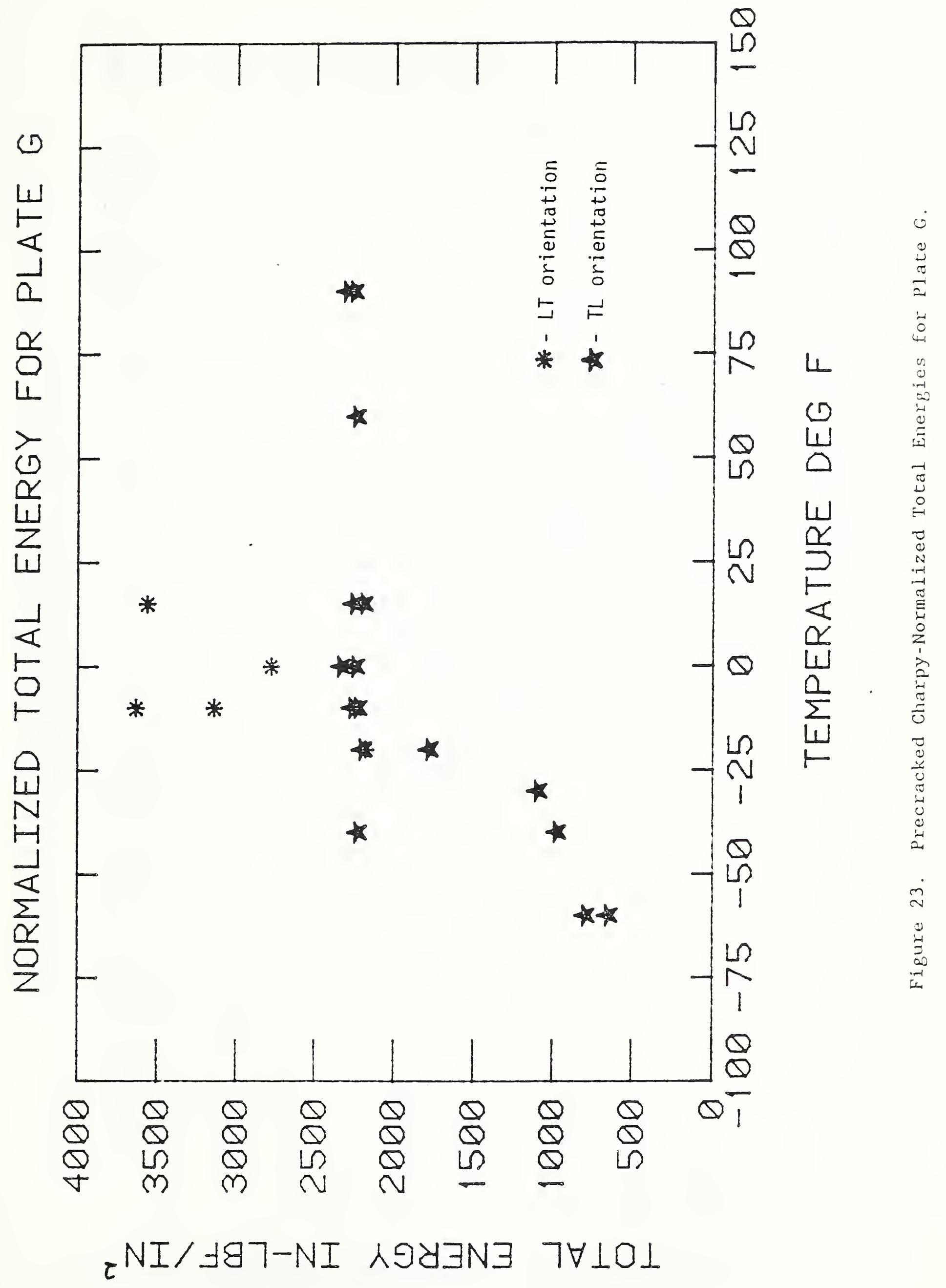




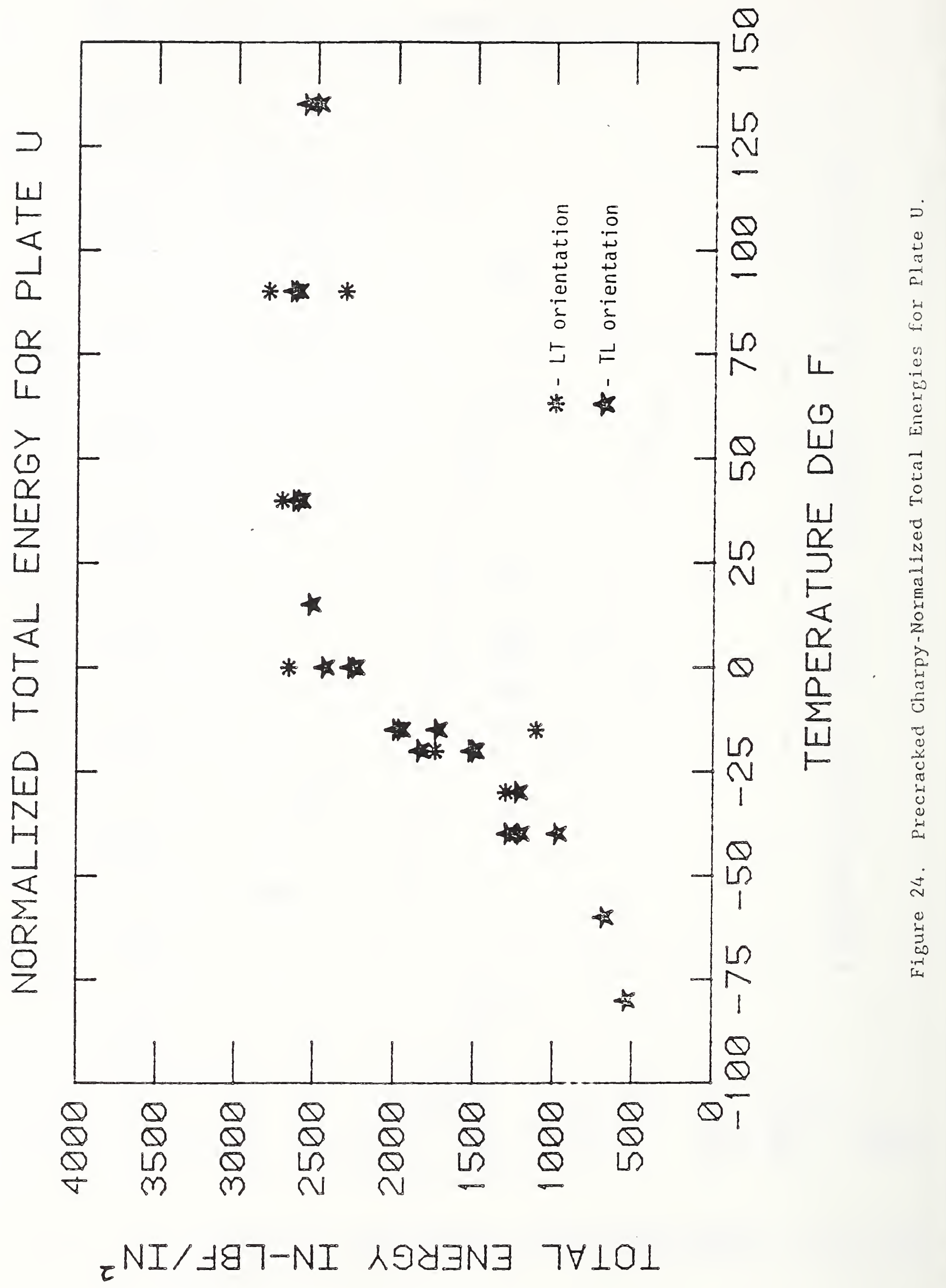




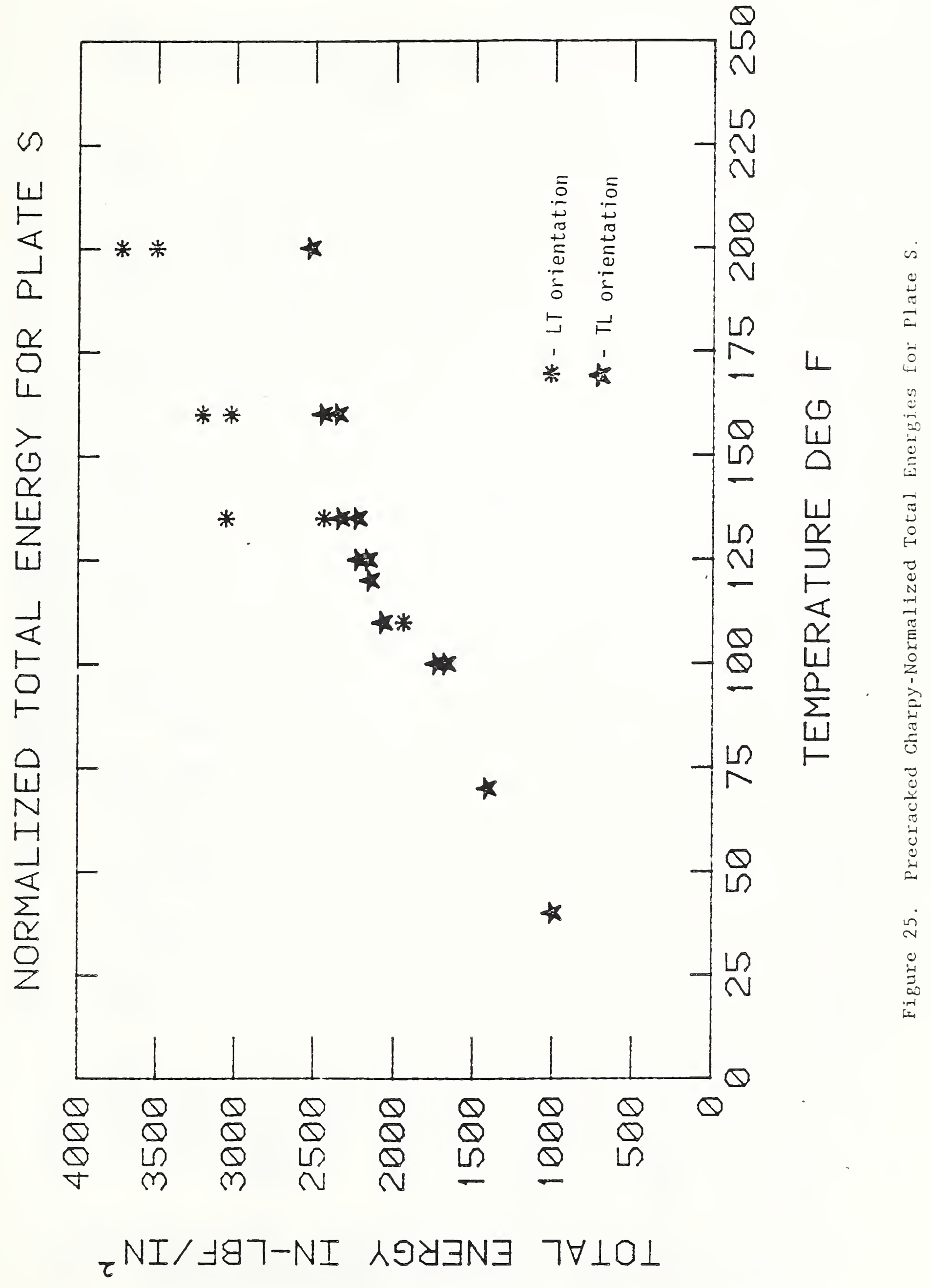




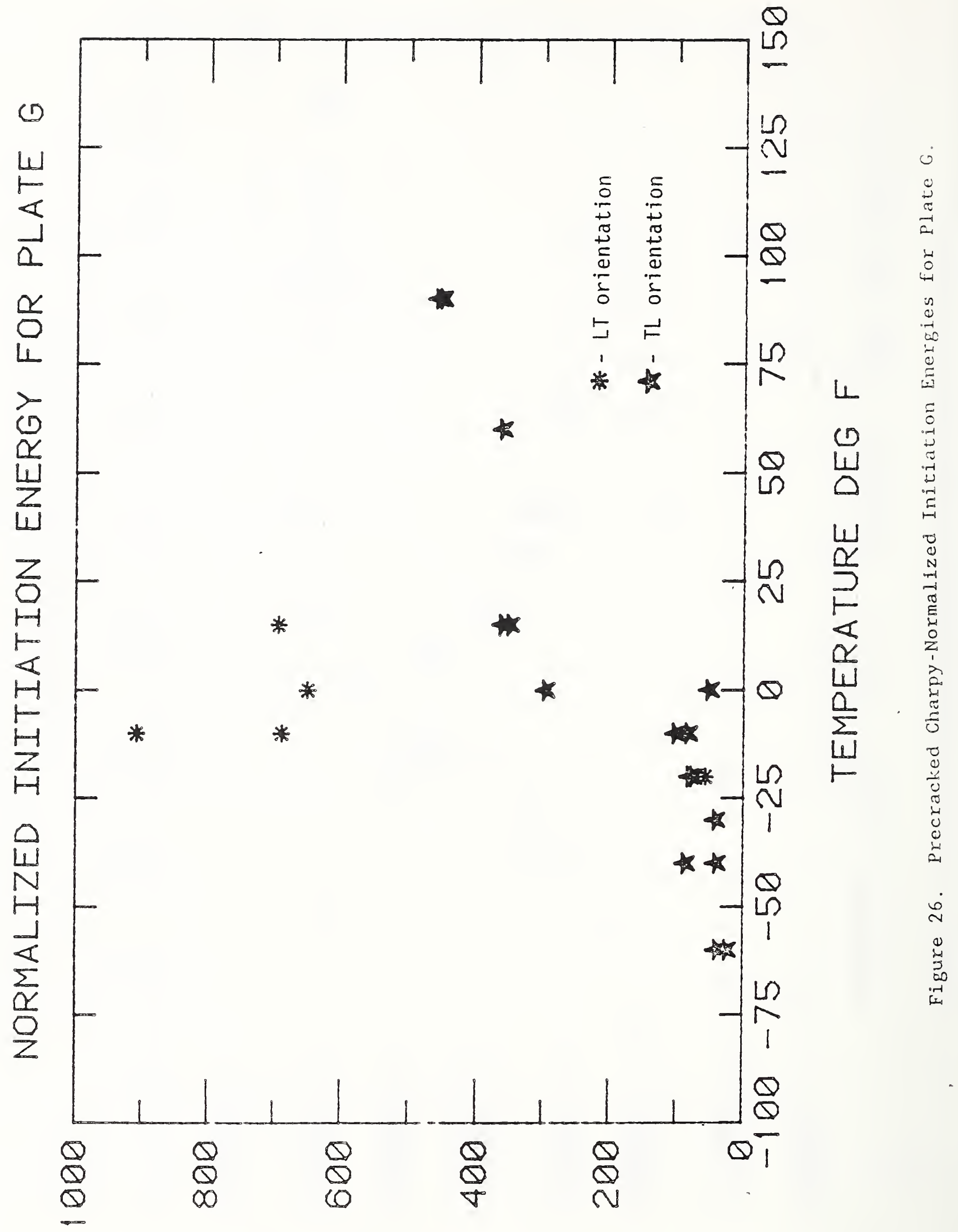

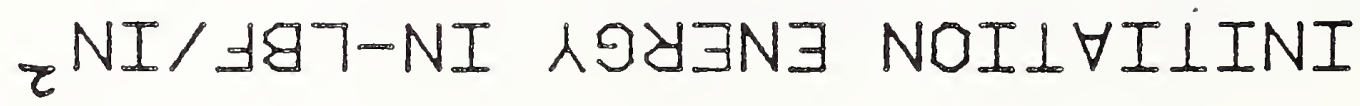




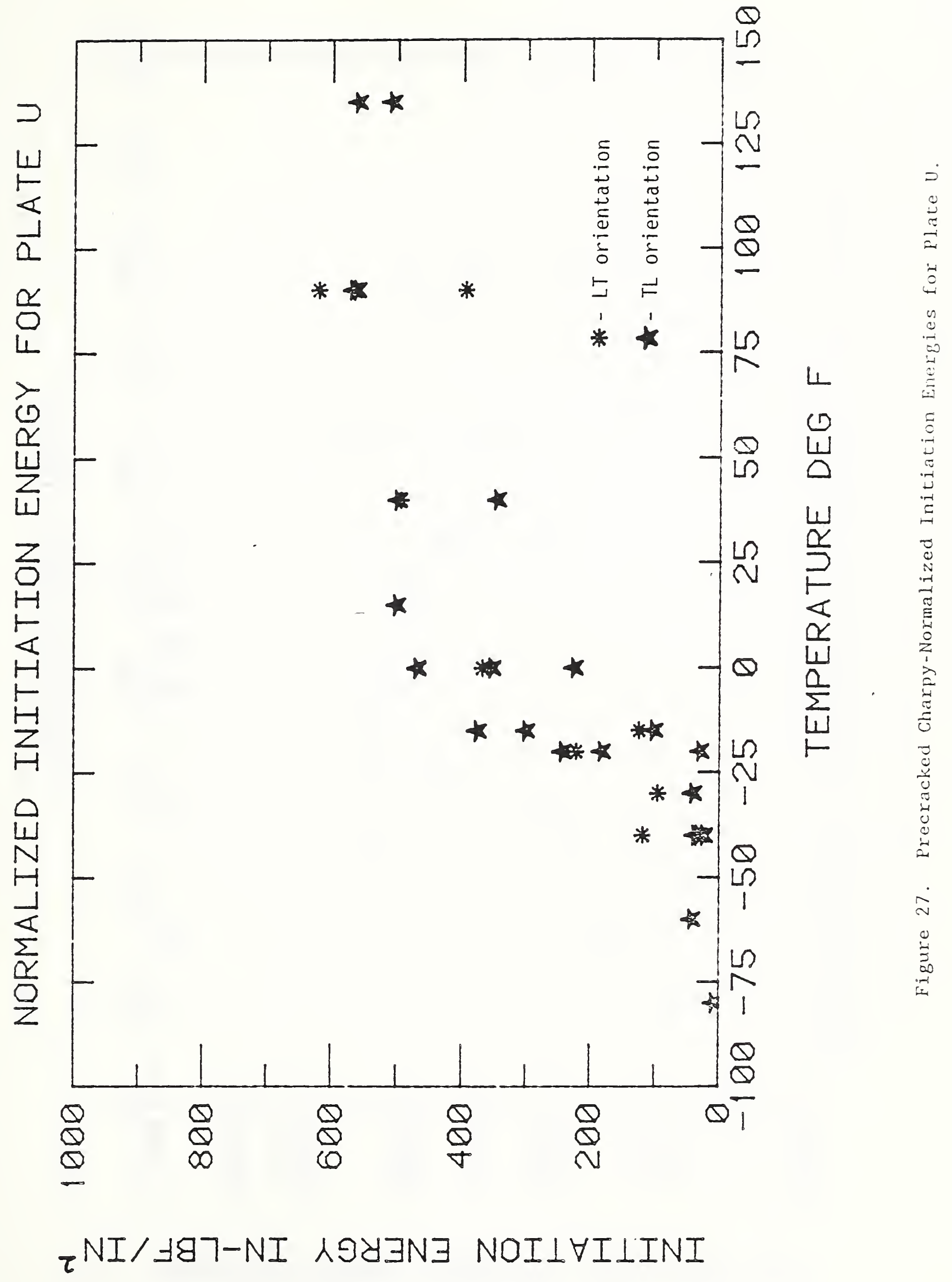




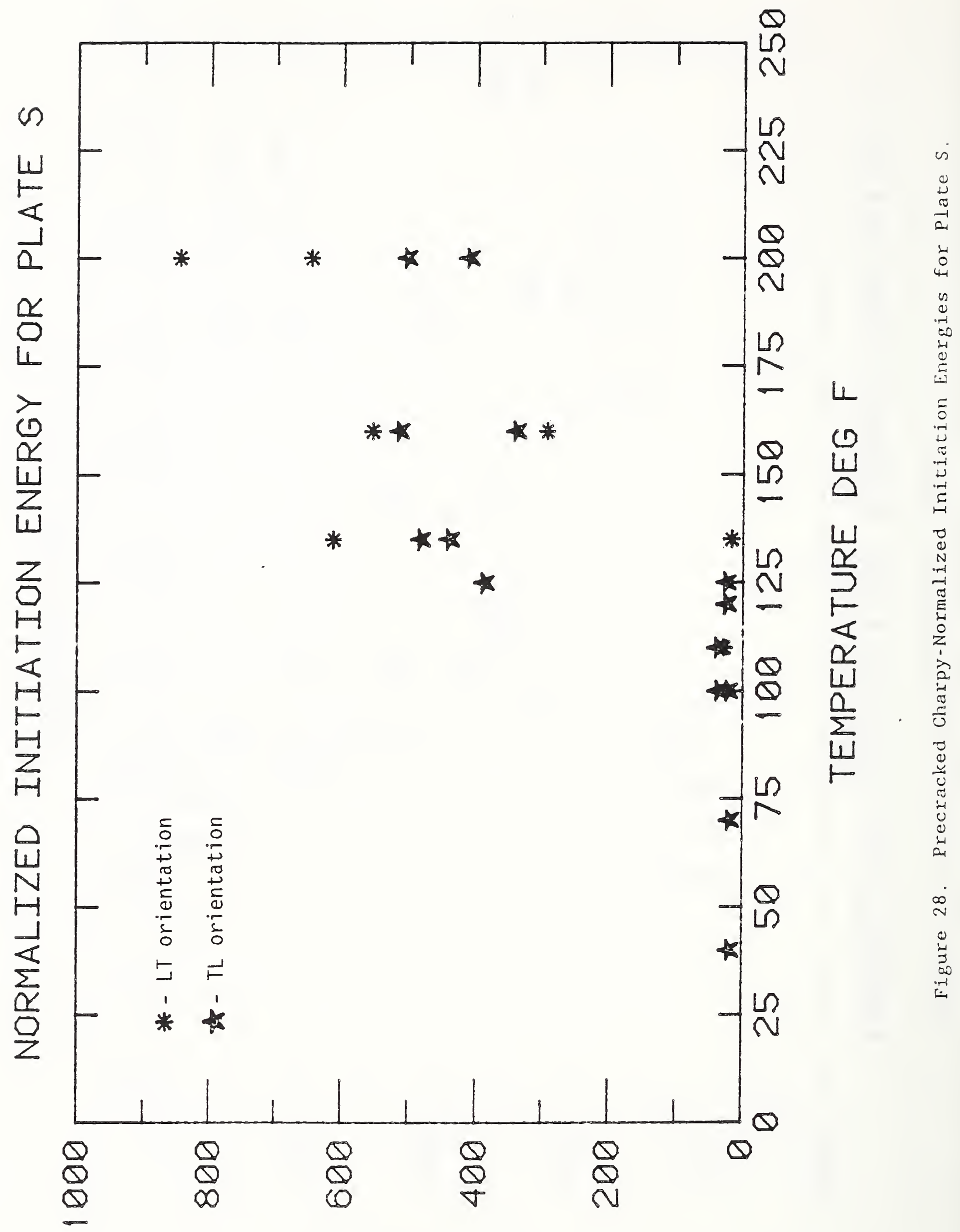

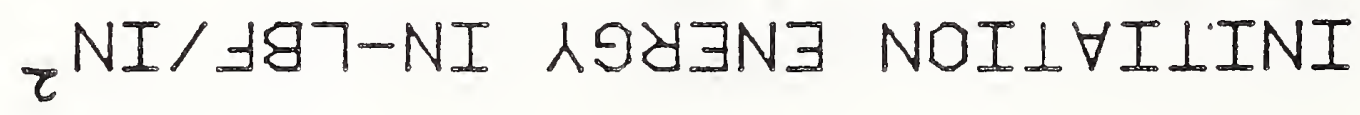




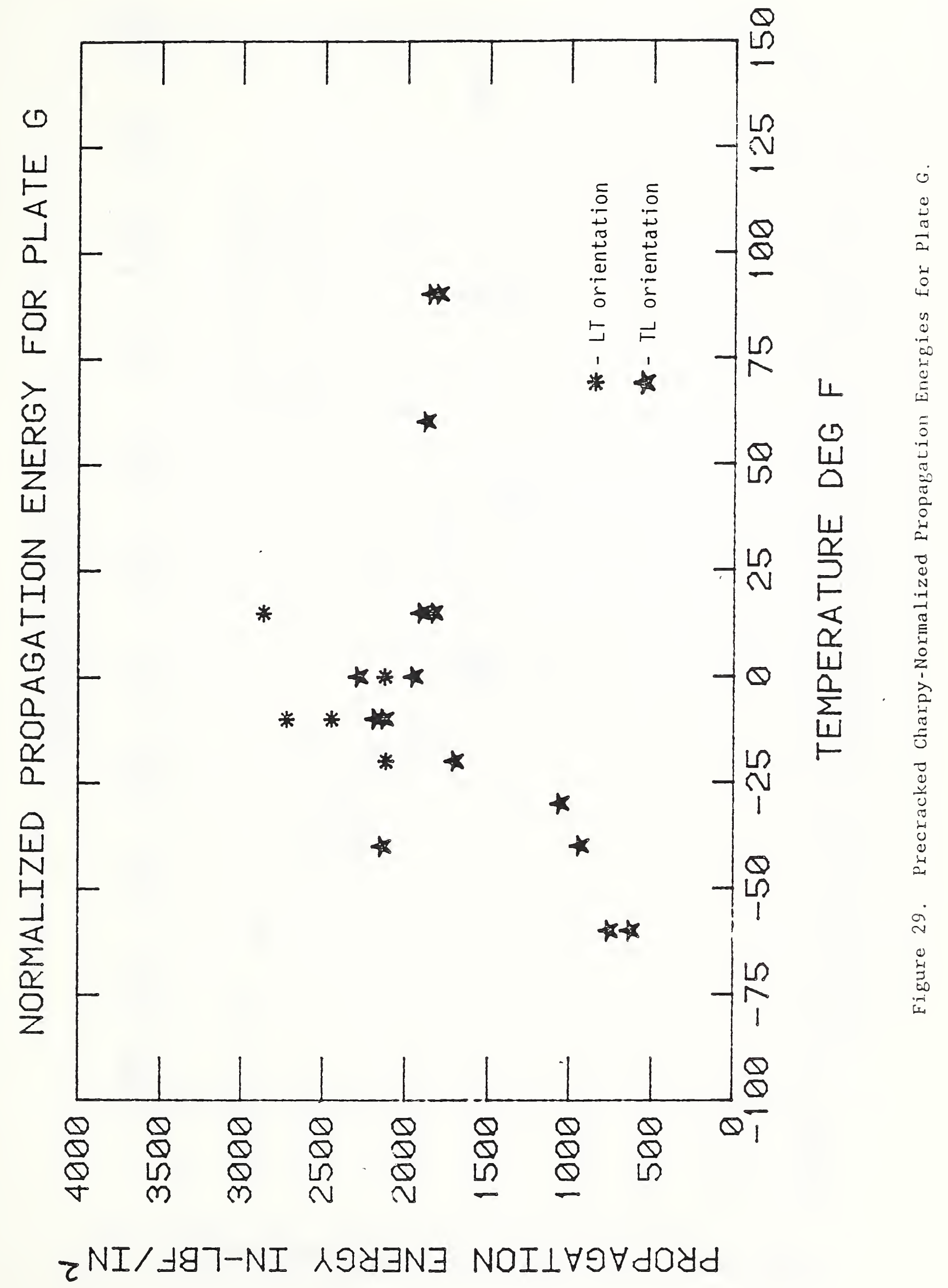




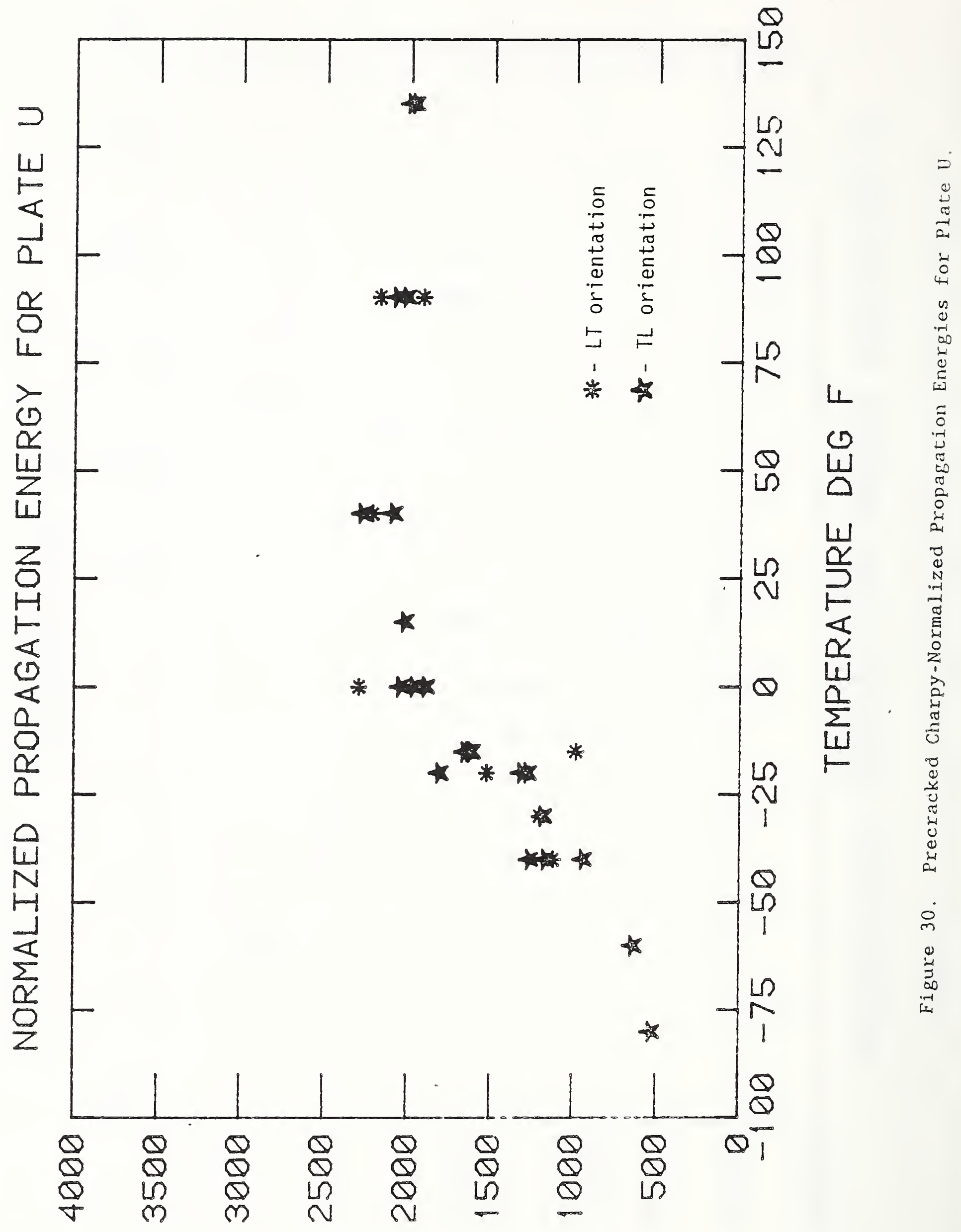

$\tau^{N I / \exists g 7-N I ~} \wedge 9 \forall \exists N \exists$ NOIL $\forall 9 \forall d O d d$ 


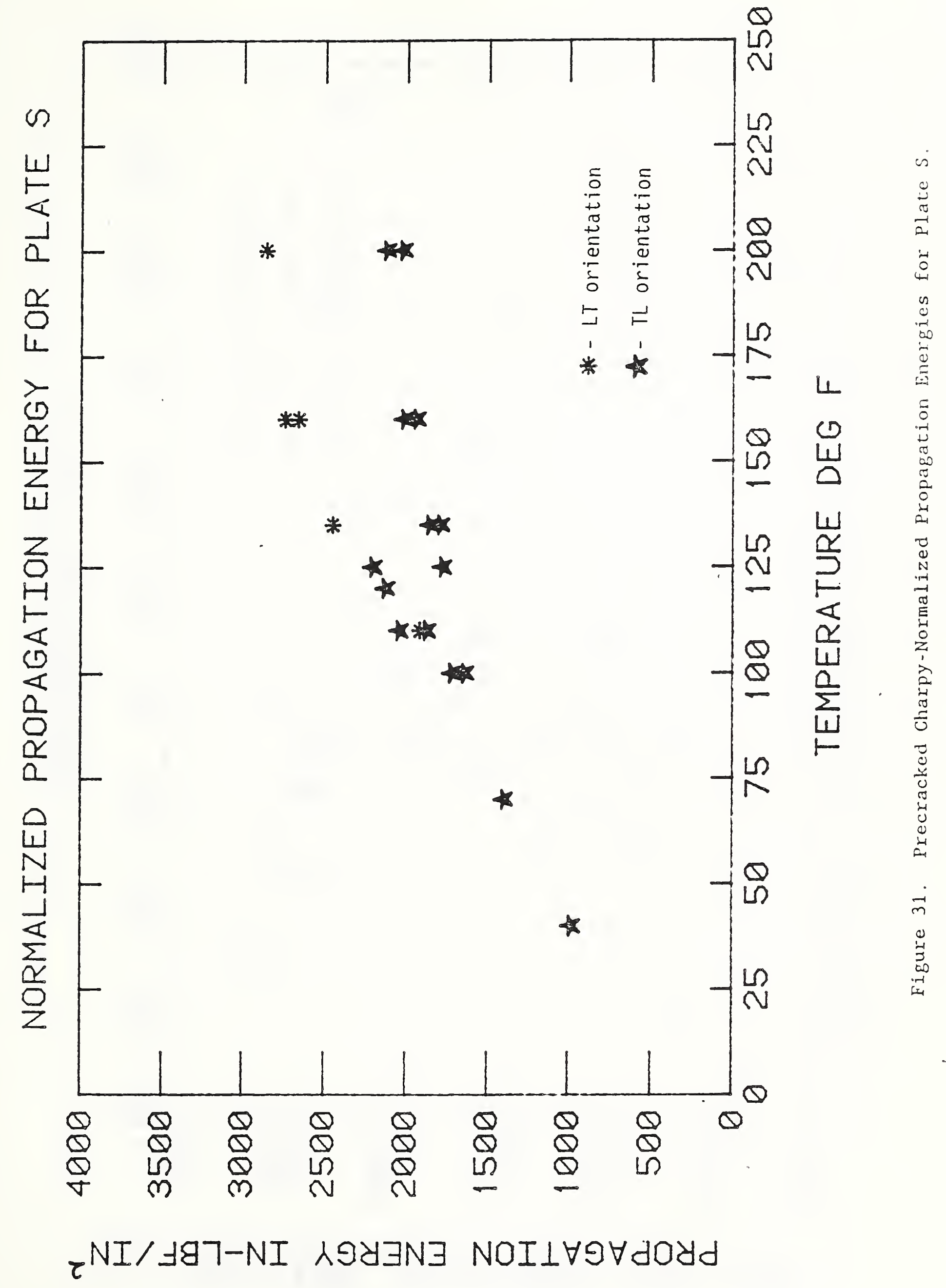




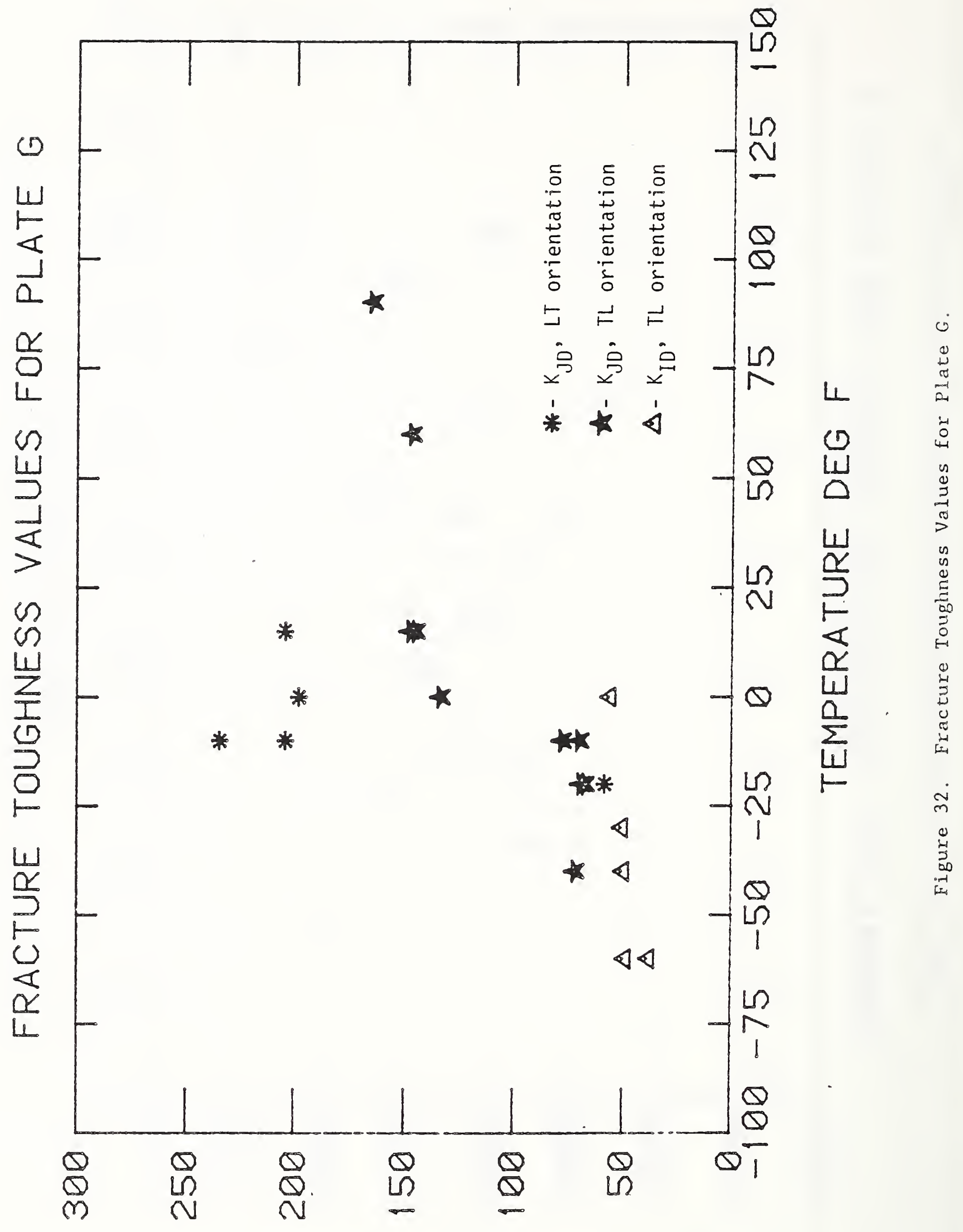

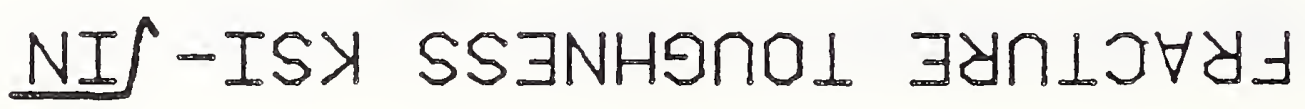




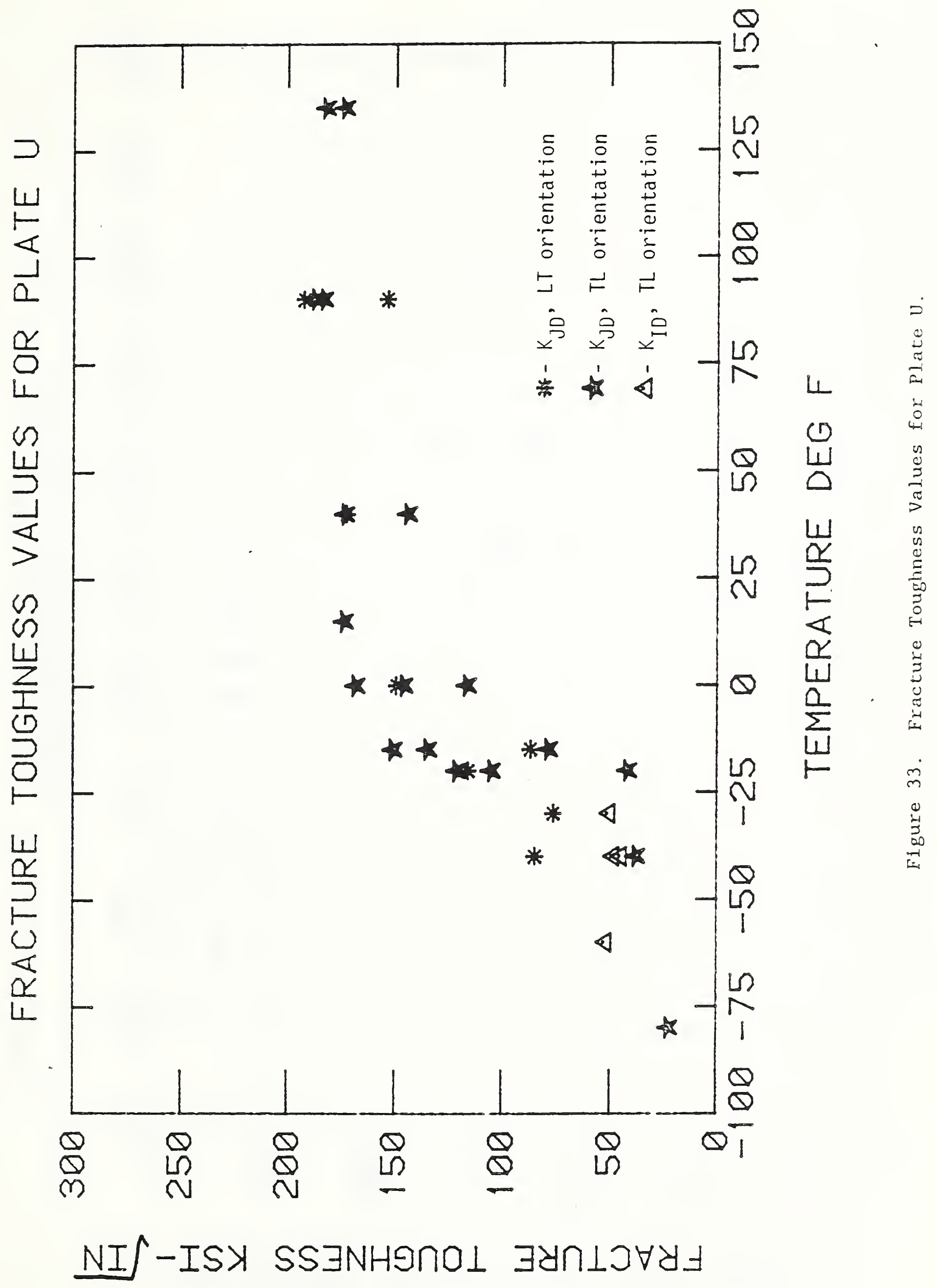




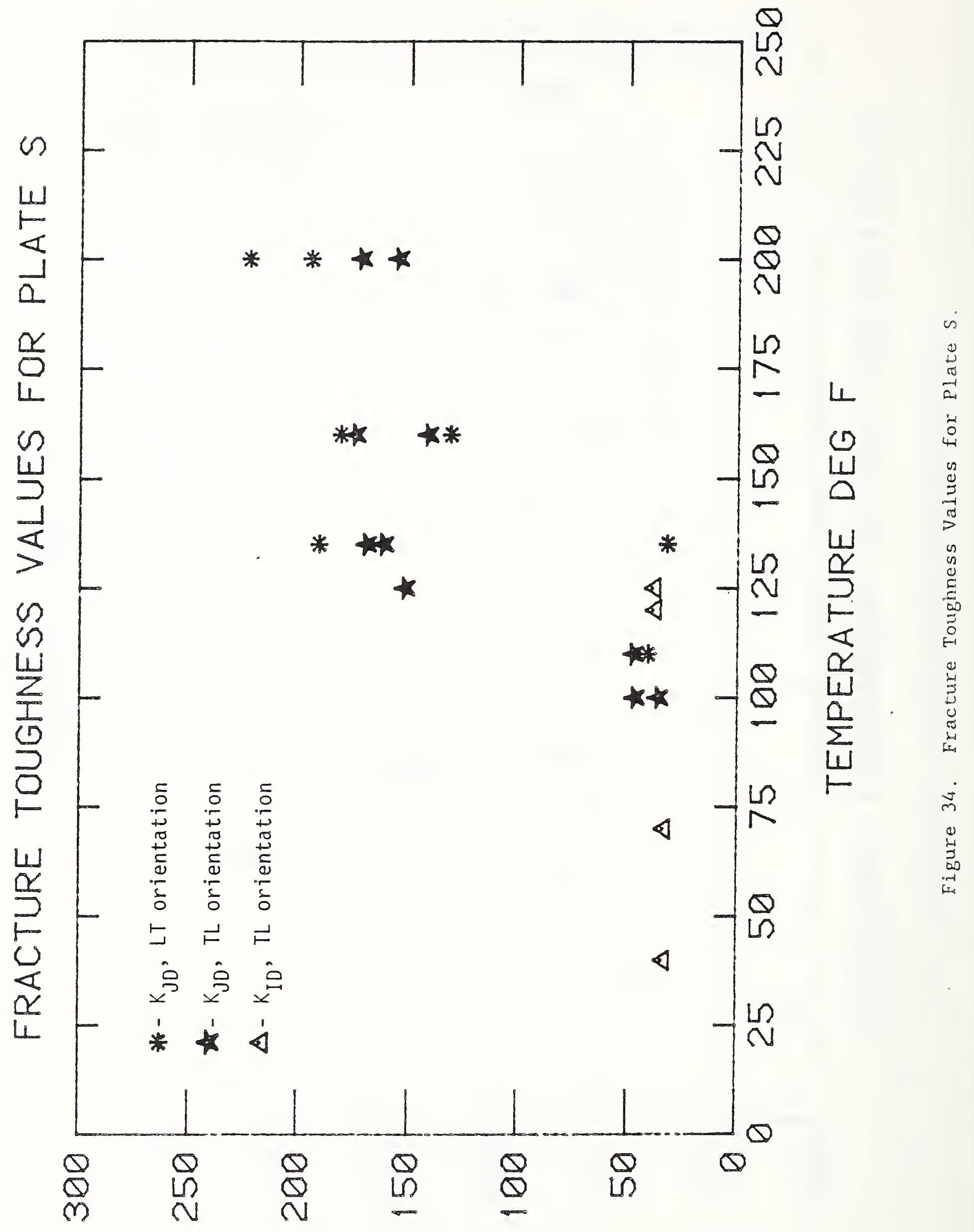

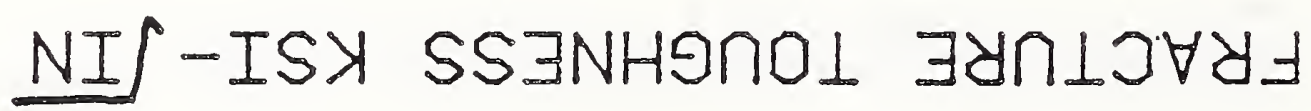




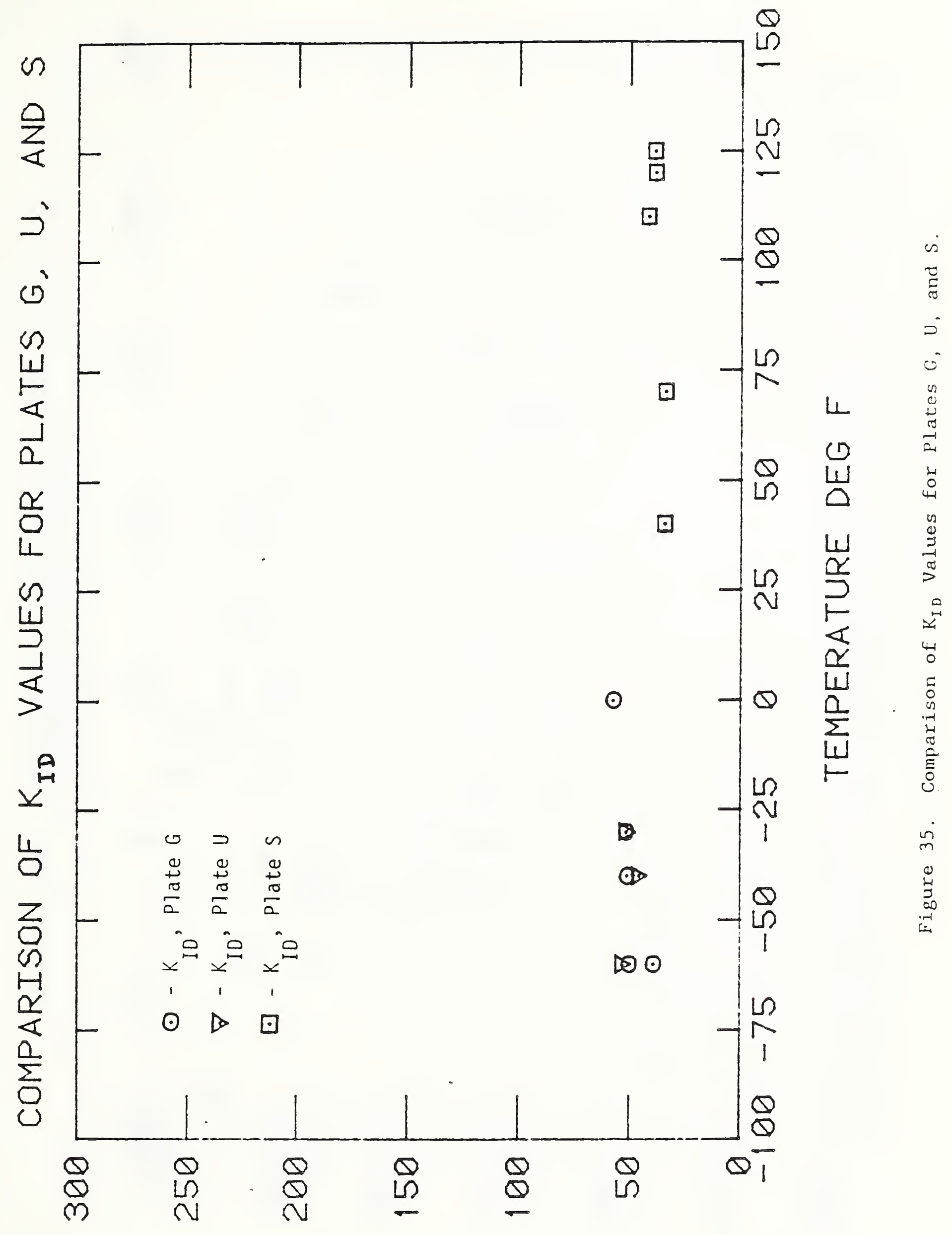

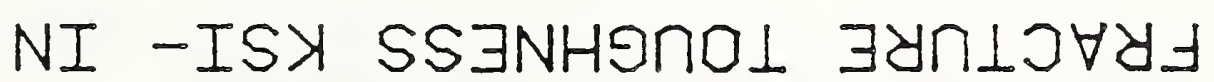




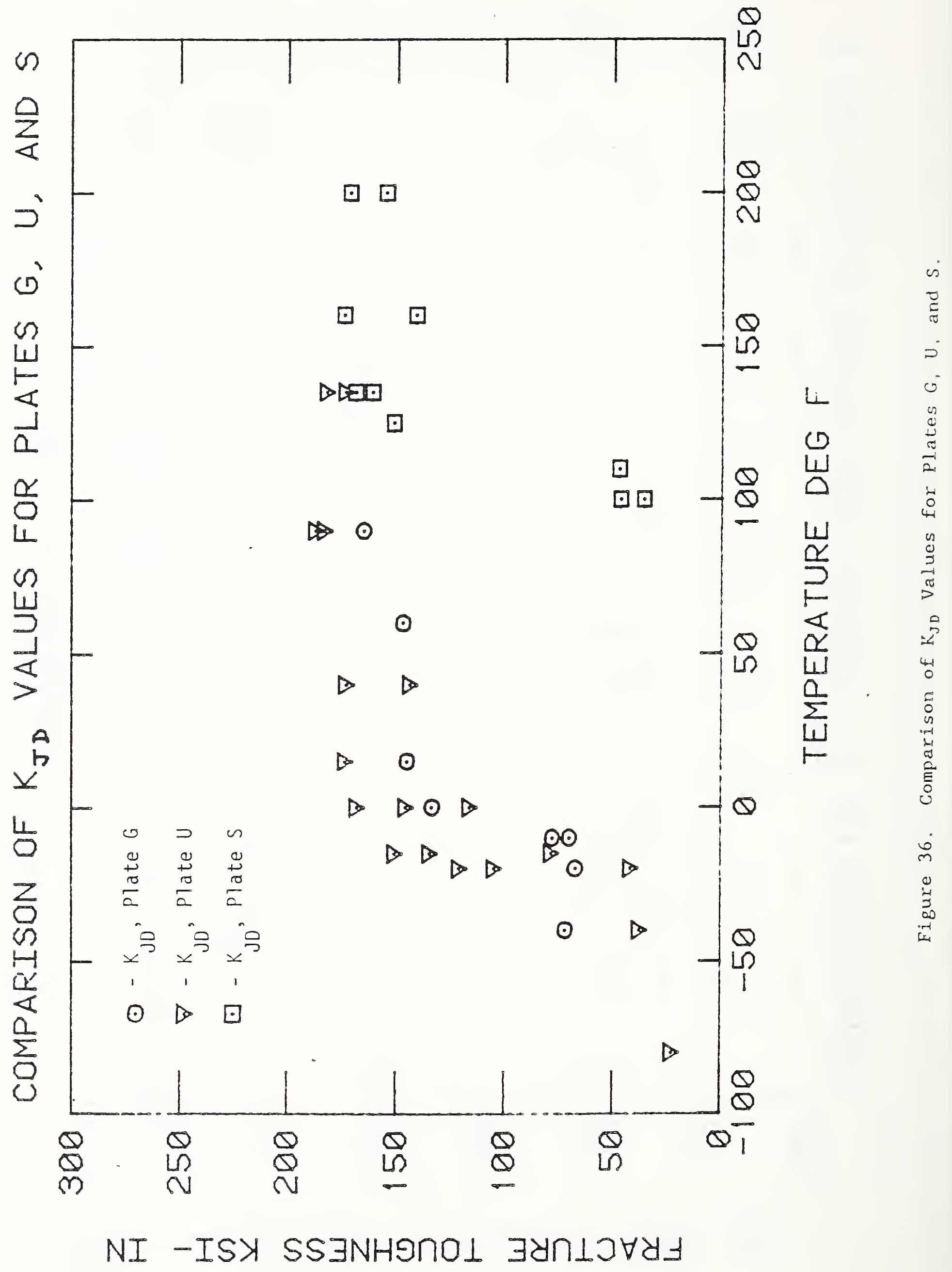




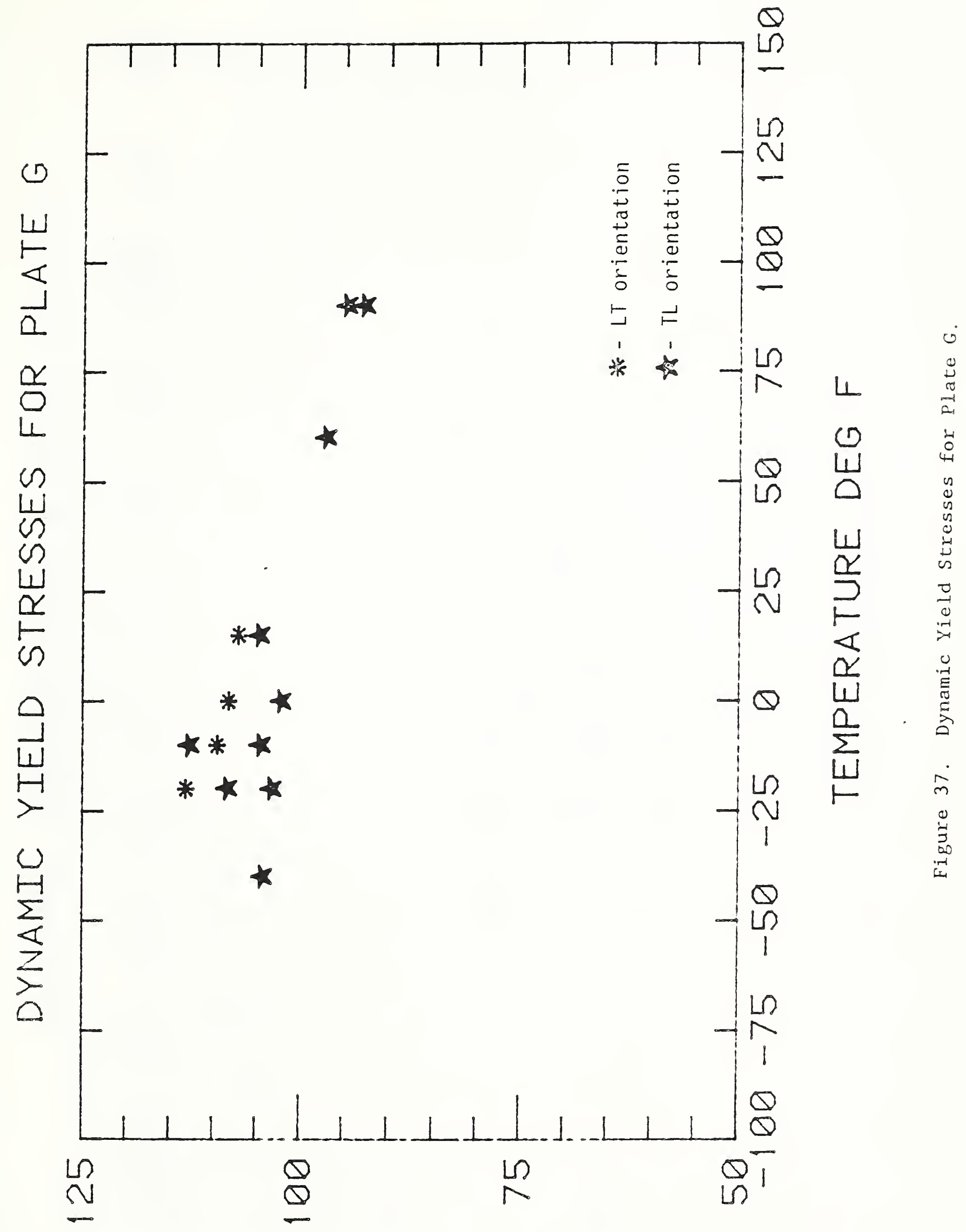

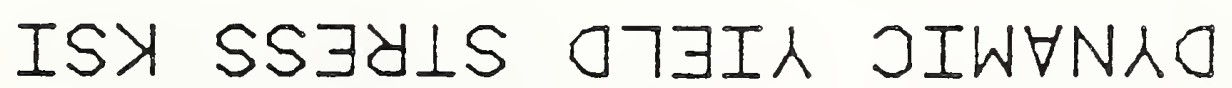




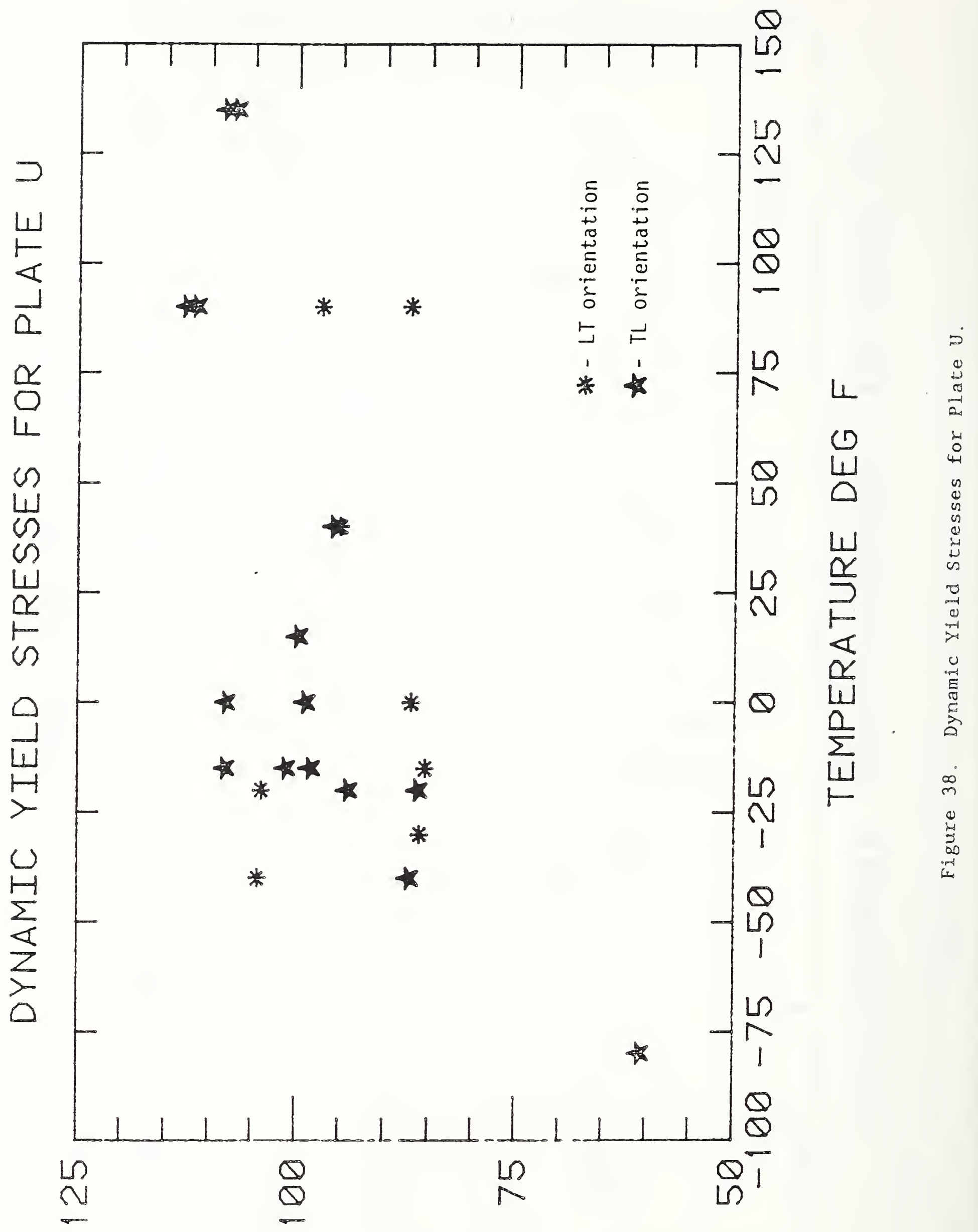

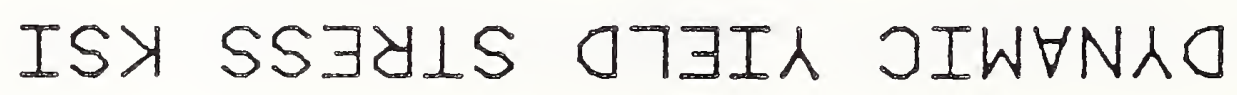




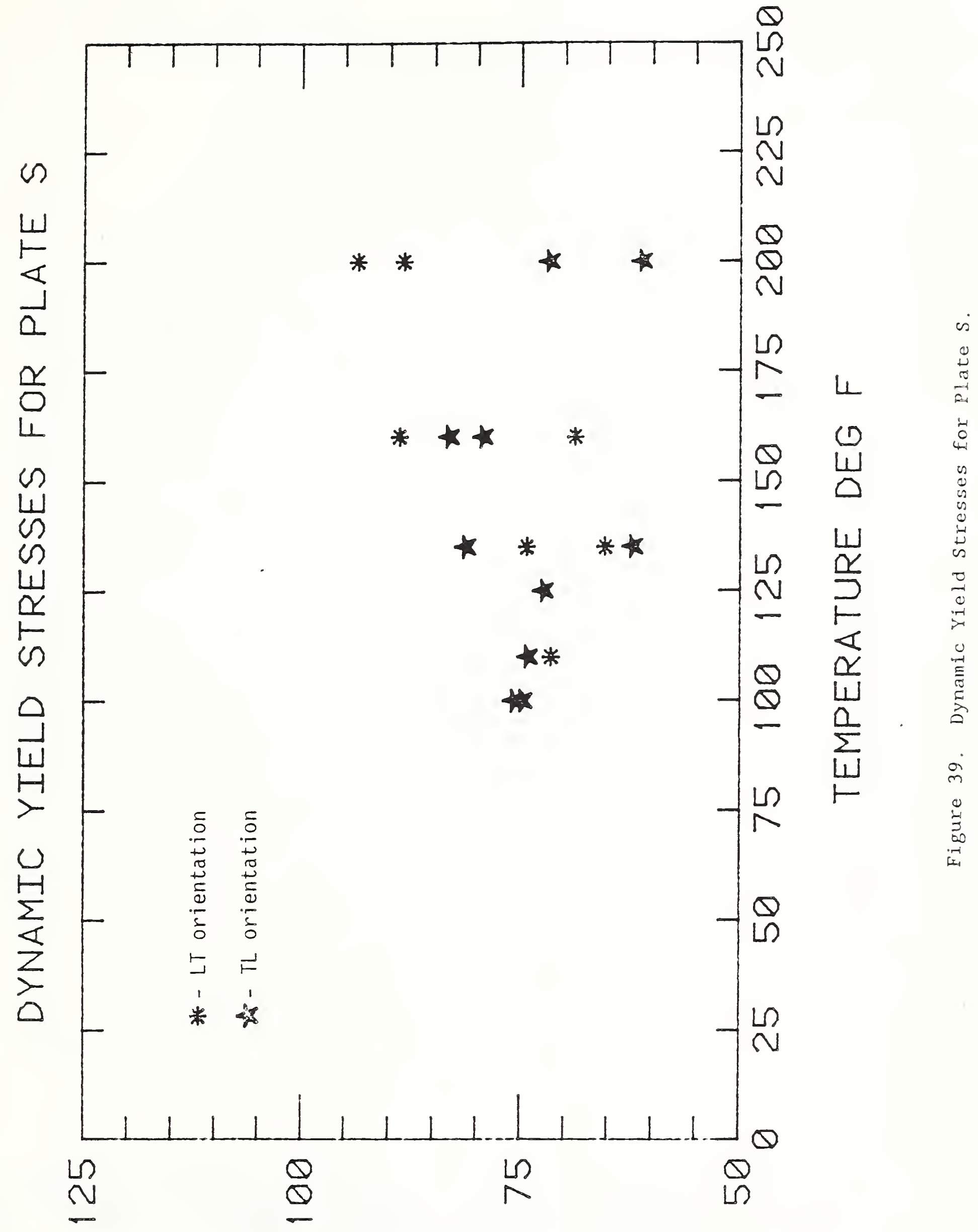

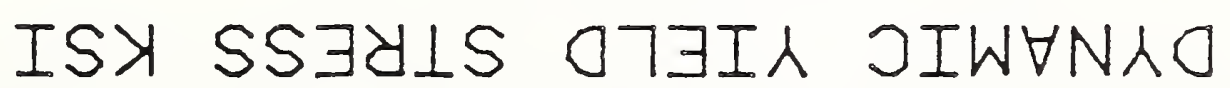




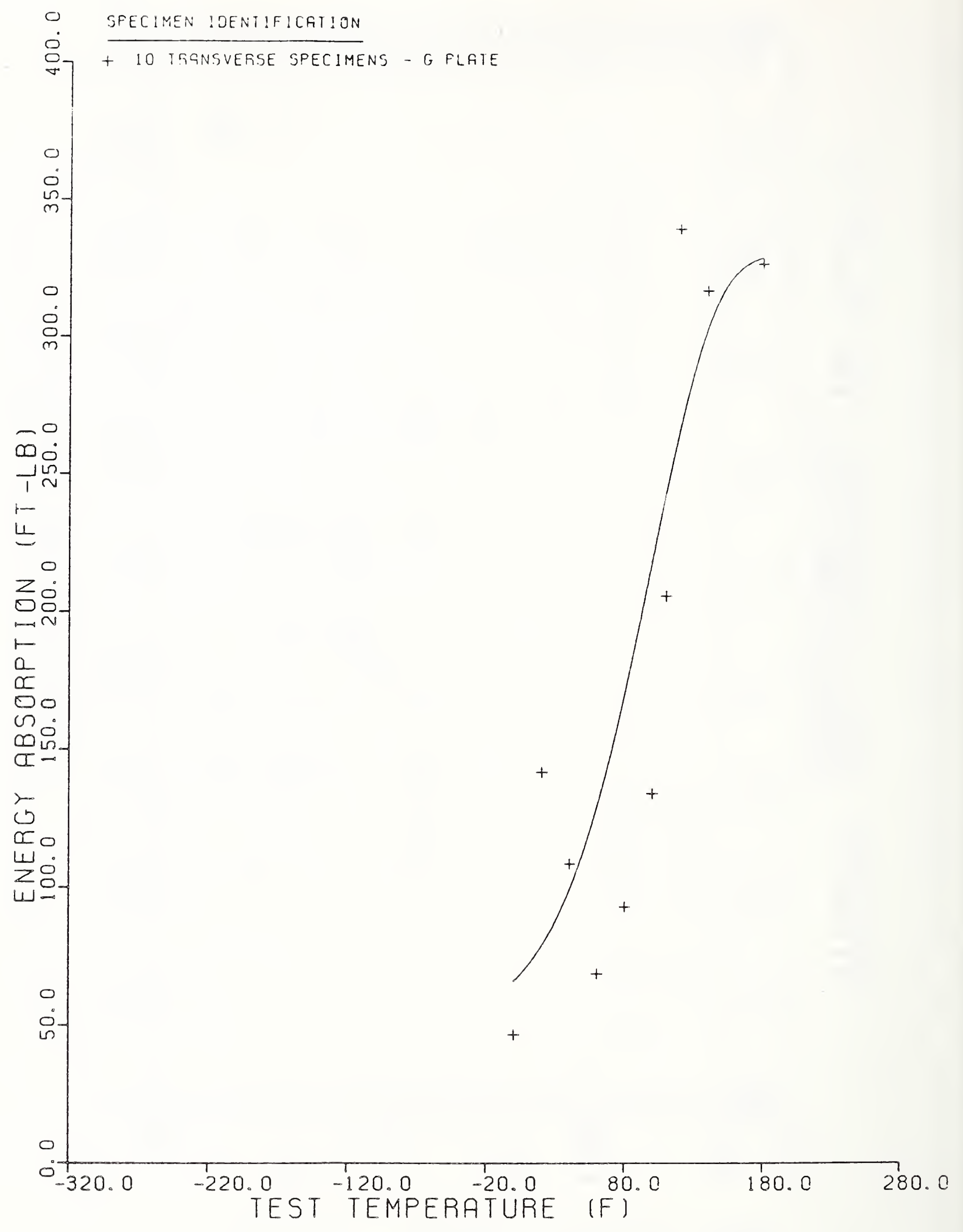

Figure 40. Dynamic Tear-Energy Absorption Values for Plate G. 


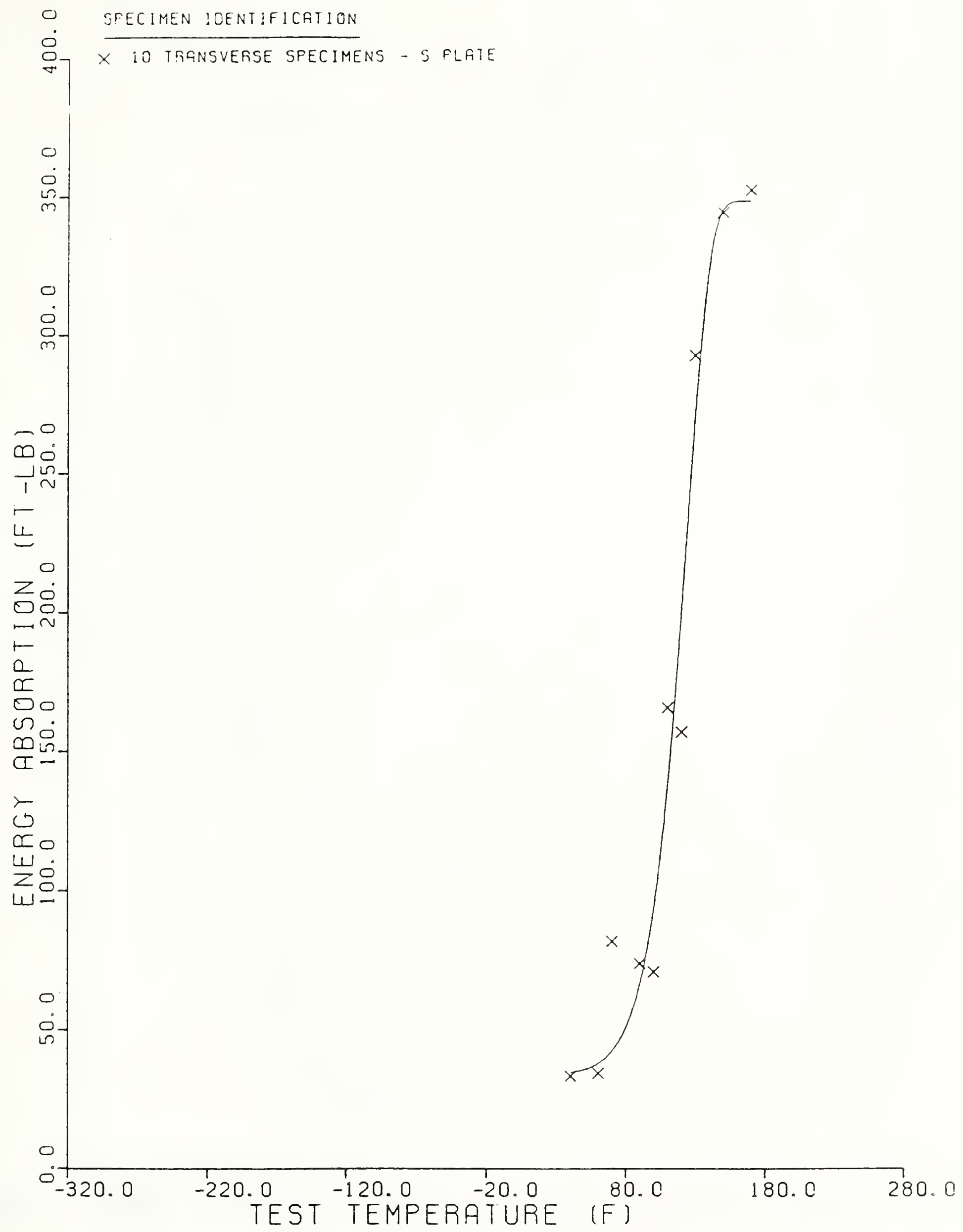

Figure 41. Dynamic Tear-Energy Absorption Values for Plate S. 


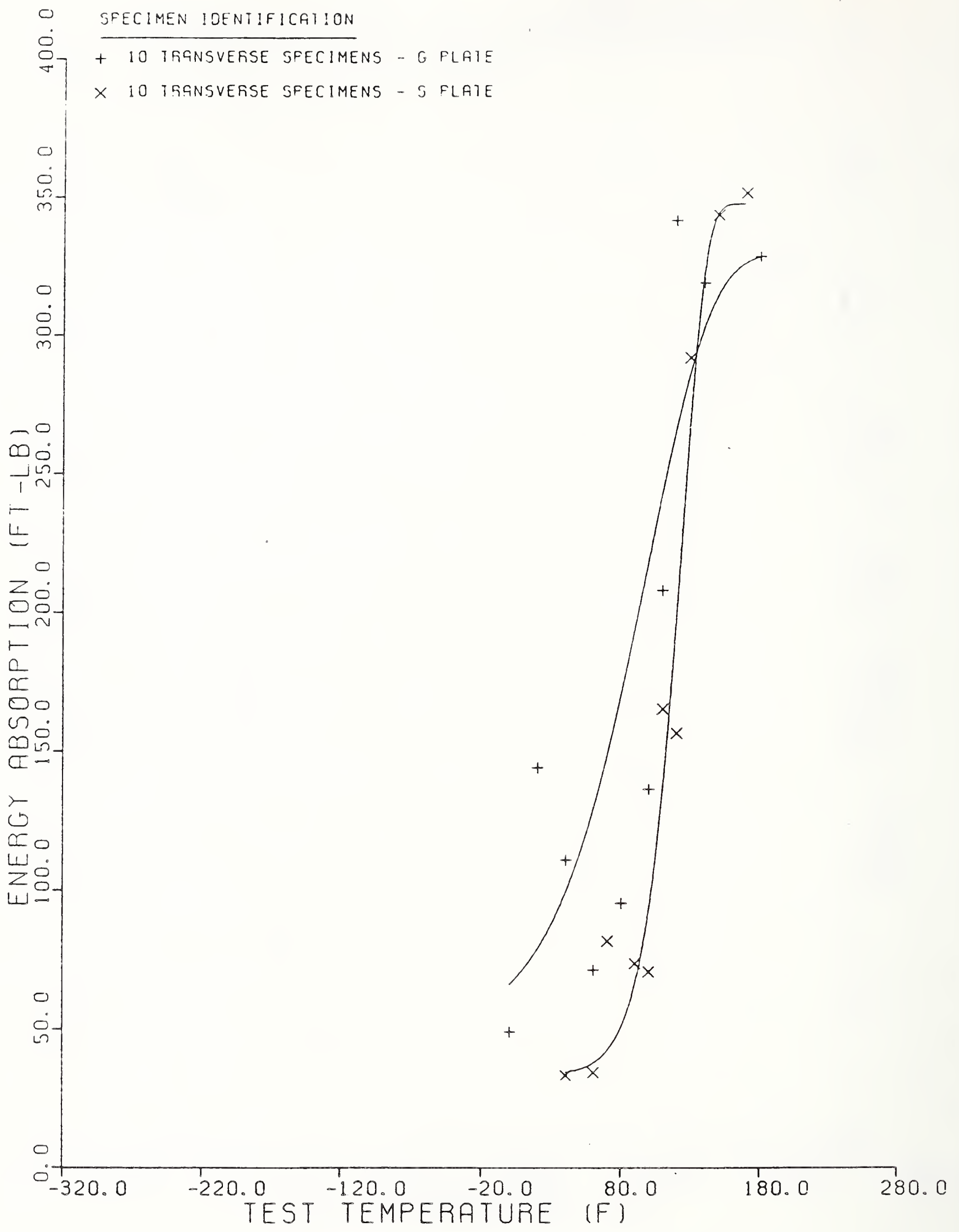

Figure 42. Comparison of Dynamic Tear Results for Plates $G$ and $S$. 


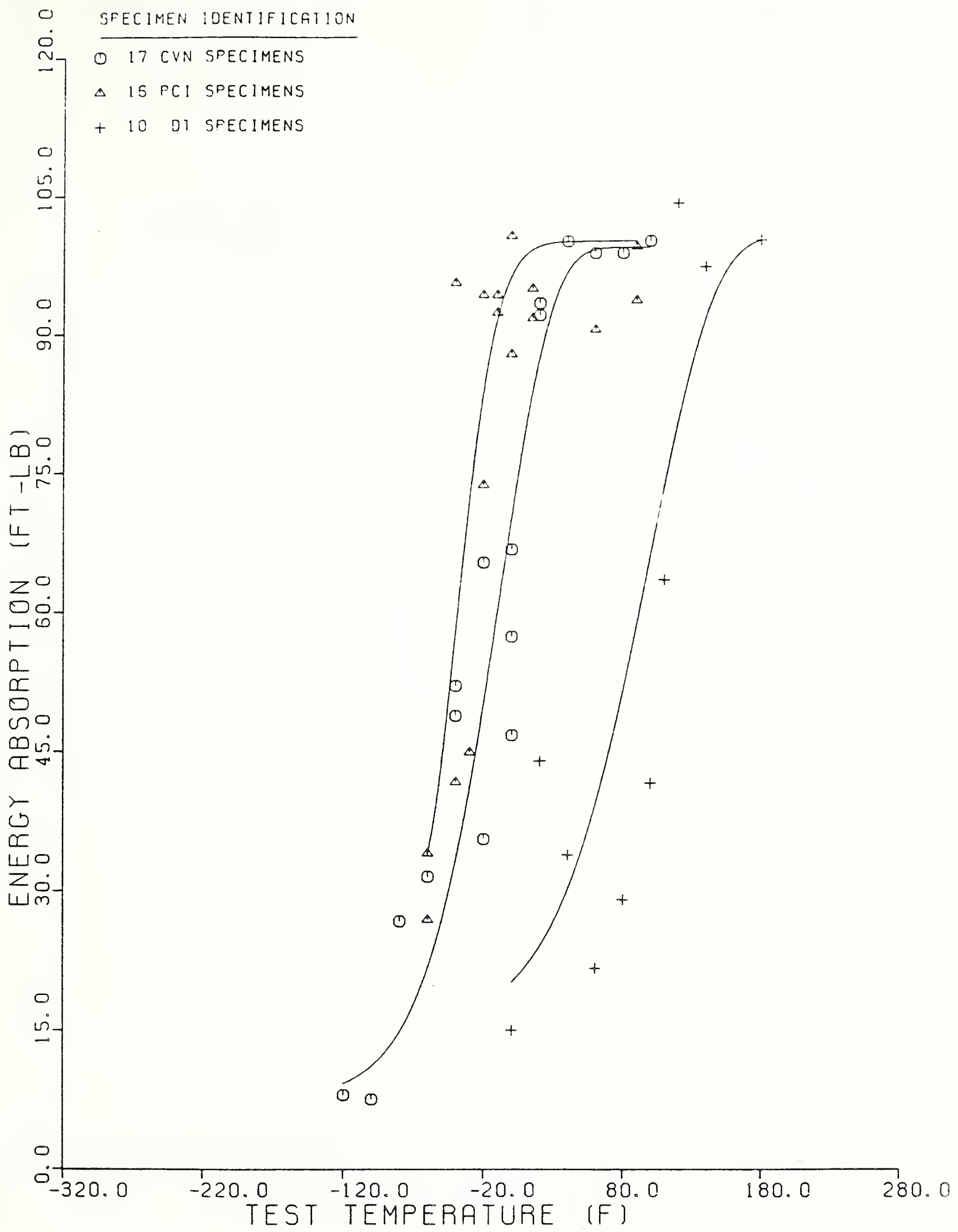

Figure 43. Comparison of Results for CVN, PCI, and DT Tests for Plate G. 


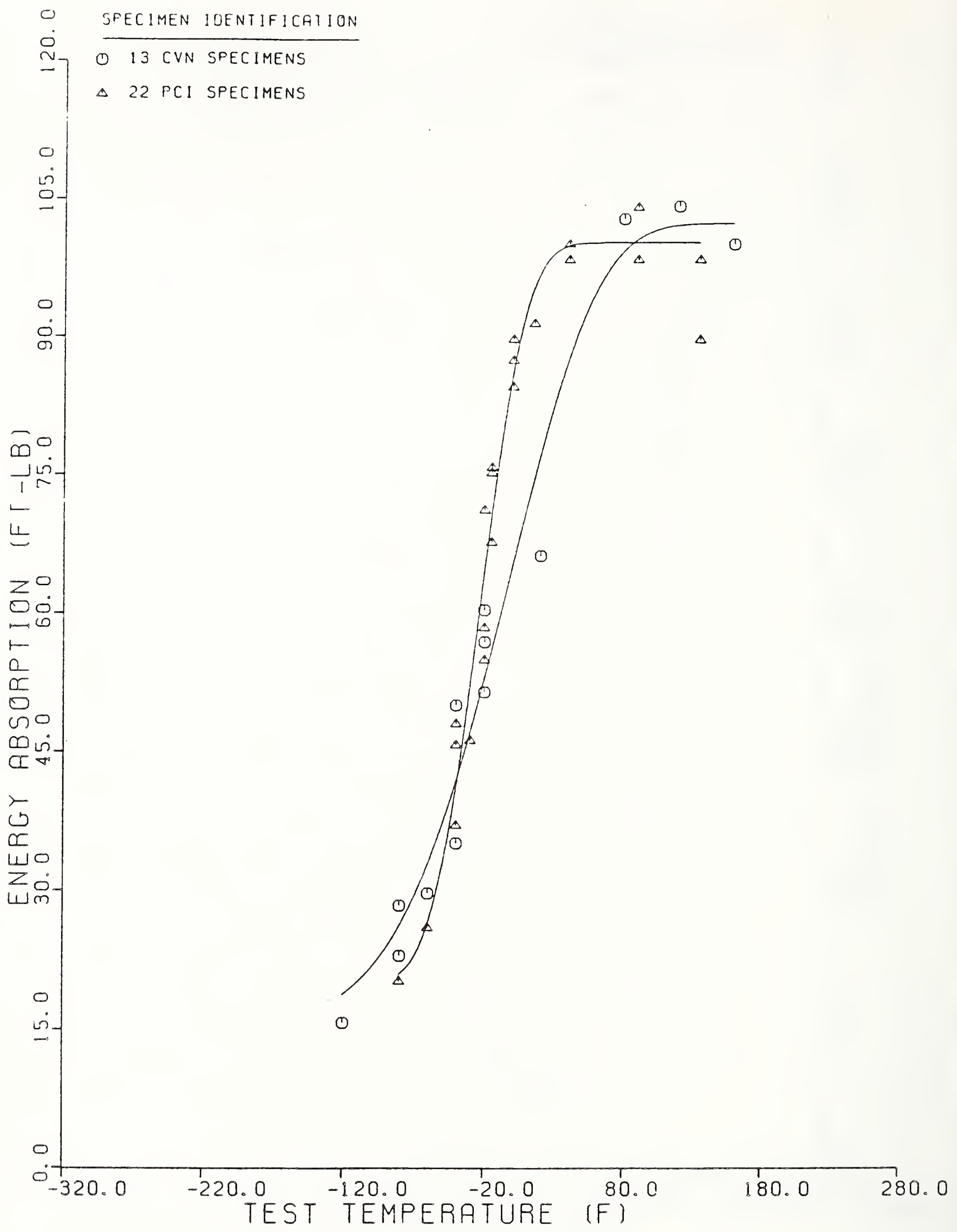

Figure 44. Comparison of Results for CVN and PCI Tests for Plate U. 


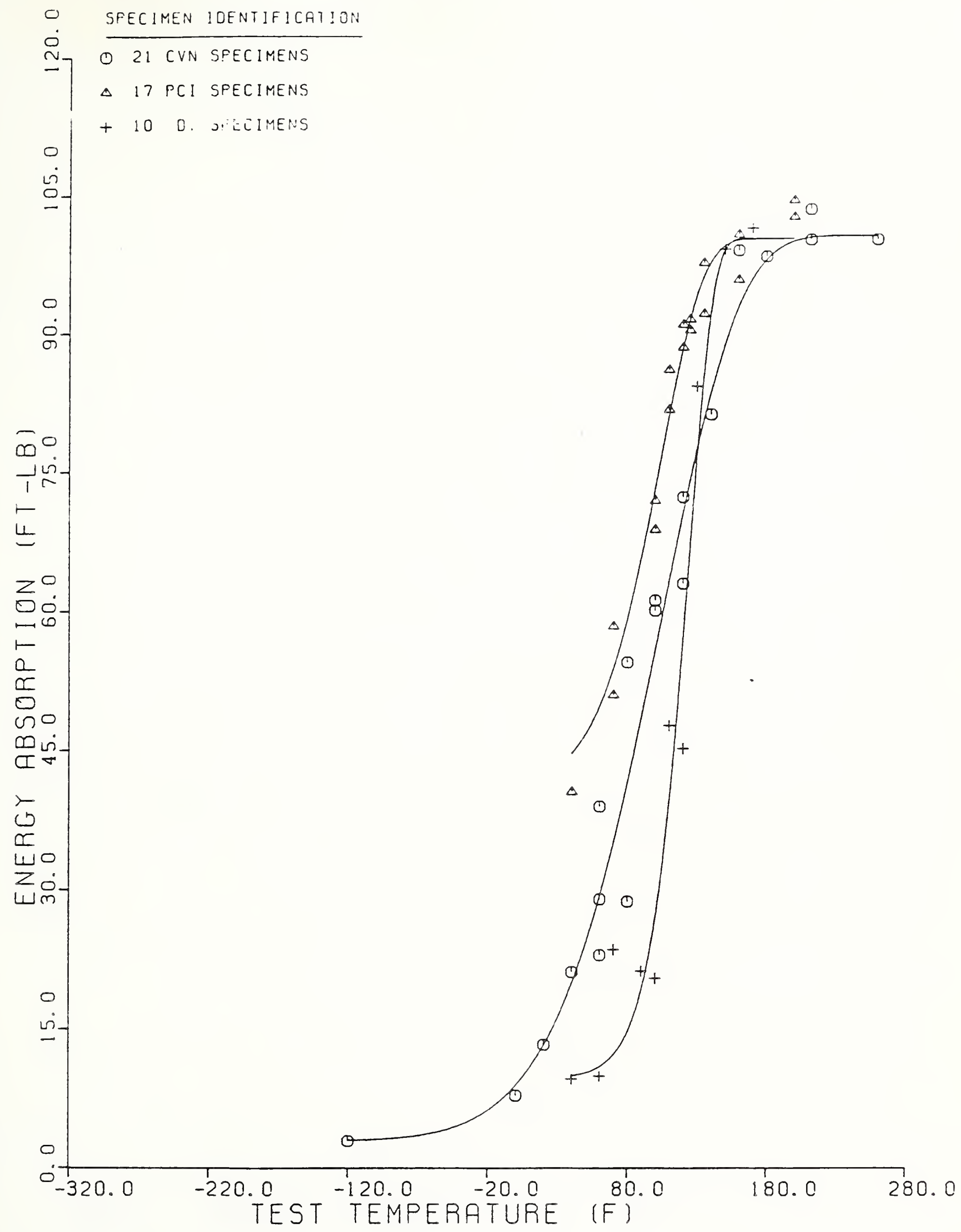

Figure 45. Comparison of Results for CVN, PCI, and DT Tests for Plate S. 



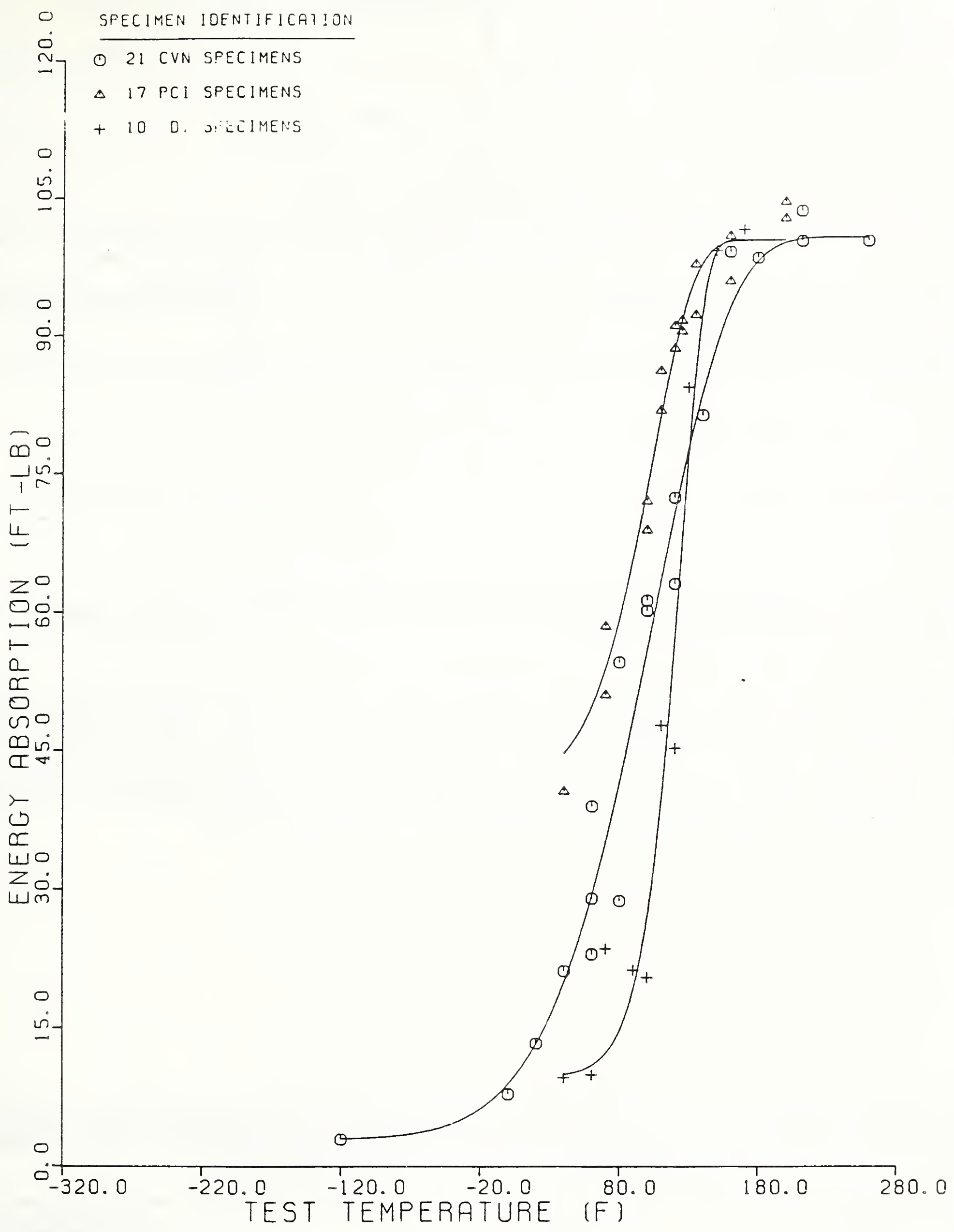

Figure 45. Comparison of Results for CVN, PCI, and DT Tests for Plate S. 


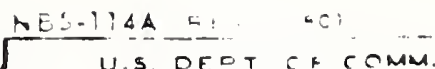

BIBLIOGRAPHIC DATA

SHEET (See instructions)
1. PEB BLICATION OR REPORT NO.

NBSIR $88-3690$

3. Publication Date

JUNE 1988

4. TITLE AND SUBTITLE

Dynamic Mechanical Properties of Two AAR M128 and One ASTM A212-B Steel Tank Car Head Plates

5. AUTHOR(S)

3.G. Early, C.G. Interrante, S.R. Low III, and B.A. Fields

6. PERFORMING ORGANIZATION (If joint or other than NBS, see instructions)

7. Contracd Grans No.

\section{NATIONAL BUREAU OF STANDARDS \\ U.S. DEPARTMENT OF COMMERCE \\ GATTHERSBURG, MD 20899}

9. SPONSORING ORGANIZATION NAME AND COMPLETE ADDRESS (Street, City, Stote, ZIP)

Federal Railroad Administration

Department of Transportation

Washington, D.C.

10. SUPPLEMENTARY NOTES

Document describes a computer program; SF-185. FIPS Software Summary, is attached.

11. ABSTRACT (A 200-word or less factual summory of most significant information. If document includes a significant bibliography of literature survey. mention it here)

Instrumented precracked Charpy impact testing and dynamic teat testing were carried out on steel plate samples taken from three railroad tank cars. Two of the samples were given as AARM128, a high strength carbon manganese steel, while the third was reported to be ASTM A212-65, a high strength carbon silicon steel. Values were found for the ranges of transition temperatures and for the energies absorbed, including crack initiation energy, crack propagation energy and total energy.

12. KEY WORDS (Six to twelve entries; alphobetical order: capitalize only proper names; and separate key words by semicalons) crack initiation; crack propagation; dynamic mechanical properties; high strength steel; impact fracture; railorad tank car; transition temperature

\section{AVAILABILITY}

$\mathrm{X}$ Unlimited

For Official Distriburion. Do Not Release to NTIS

Order From Superintendent of Documents, U.S. Government Printing Office, Washington. D.C. 20402.

$[\mathrm{X}$ Ordep From National Technical Information Service (NTIS), Springfield, VA. 2216I
14. NO. OF

PRINTED PAGES

98

15. Price 

